\title{
Recent and subrecent diet of the barn owl (Tyto alba) in Slovakia
}

\author{
Recentná a subrecentná potrava plamienky driemavej (Tyto alba) na Slovensku
}

\author{
Ján OBUCH, Štefan DANKO \& Michal NOGA
}

\begin{abstract}
We completed data on the diet of the barn owl (Tyto alba) predominately from pellets for the period of the last 50 years from Slovakia. We analyzed material from 251 locations and 16 territorial units. The aggregate represents 119,231 pieces of prey from 47 species of mammals (Mammalia, 95.7\%) and 58 species of birds (Aves, 3.9\%), with a small representation of amphibians, reptiles (Amphibia and Reptilia, $0.2 \%$ ) and invertebrates (Invertebrata, $0.2 \%$ ). The obtaining of food among the owls is limited to synanthropic environments and the surrounding agricultural landscape, and the centre of its distribution in the recent period (i.e. the past 50 years: 1965-2015) has been concentrated mainly on the southern parts of Slovakia. In this environment the common vole (Microtus arvalis, 59.6\%) is the primary prey. Additional prey are rodents of the family Muridae: Mus musculus (5.6\%), Micromys minutus (2.2\%), Apodemus microps (2.2\%), A. flavicollis (2.0\%), A. sylvaticus $(1.6 \%)$ and A. agrarius $(1.5 \%)$; insectivores of the family Soricidae: Sorex araneus (6.2\%), S. minutus (2.4\%), Crocidura leucodon (4.8\%) and C. suaveolens (2.8\%); and the house sparrow Passer domesticus (2.9\%). In the higher situated Turčianska kotlina Basin the species M. arvalis (74.3\%) has higher domination, and instead of the white-toothed shrews the water shrews Neomys anomalus (2.8\%) and N. fodiens $(1.3 \%)$ are more abundantly represented. In 3 localities owls focused on hunting bats; for example, in the church in Ratková the order Chiroptera made up $35.2 \%$ of prey. From the subrecent period (i.e. from before more than 50 years ago) we evaluate 4 samples from the territory of Slovakia with 15,601 pieces of prey of $T$. alba. Before more than 50 years ago owls were also more abundantly represented at higher elevations in Slovakia, evidence of which is Weisz's collection of pellets from 16 localities in the Ondavská vrchovina Upland in the years 1945 to 1963 , but also a registry of data from the $19^{\text {th }}$ and $20^{\text {th }}$ centuries from higher located basins. In 4 samples of food from the subrecent period diversity in the representation of owl prey is higher, accompanied by low domination of M. arvalis and a more abundant representation of murids from the genera Mus and Apodemus. The oldest sample, dated to the $16^{\text {th }}$ century, is from a church in Žilina-Rudiny.
\end{abstract}

\begin{abstract}
Abstrakt: Skompletizovali sme údaje o potrave plamienky driemavej (Tyto alba) prevažne z vývržkov za obdobie posledných 50 rokov zo Slovenska. Analyzovali sme materiál z 251 lokalít a 16 územných celkov. Súhrn predstavuje 119231 kusov koristi zo 47 druhov cicavcov (Mammalia, 95,7 \%), 58 druhov vtákov (Aves, 3,9 \%) s malým zastúpením obojživelníkov a plazov (Amphibia a Reptilia, 0,2 \%) a bezstavovcov (Invertebrata, 0,2 \%). Získavanie potravy je u plamienky obmedzené na synantropné prostredie a na okolitú pol’nohospodársku krajinu a centrum jej rozšírenia je v recentnom období (t.j. posledných 50 rokov: 1965 - 2015) sústredené hlavne do južných častí Slovenska. V tomto prostredí je hlavnou koristou hraboš pol'ný (Microtus arvalis, 59,6 \%). Doplnkovou korist’ou sú druhy čel'ade Muridae: Mus musculus (5,6 \%), Micromys minutus (2,2 \%), Apodemus microps (2,2\%), A. flavicollis (2,0 \%), A. sylvaticus (1,6\%), A. agrarius (1,5\%), druhy čel'ade Soricidae: Sorex araneus $(6,2 \%)$, S. minutus $(2,4 \%)$, Crocidura leucodon (4,8 \%), C. suaveolens (2,8\%) a vrabec domový (Passer domesticus, 2,9 \%). Vo vyššie položenej Turčianskej kotline má $M$. arvalis $(74,3 \%$ ) vyššiu dominanciu a namiesto bielozubiek sú početnejšie zastúpené dulovnice: Neomys anomalus $(2,8 \%)$ a $N$. fodiens $(1,3 \%)$. Na 3 lokalitách sa plamienky zamerali na lov netopierov, napríklad v kostole $\mathrm{v}$ Ratkovej tvorili Chiroptera 35,2 \% koristi. Zo subrecentného obdobia (t.j. pred viac ako 50 rokmi) vyhodnocujeme z územia Slovenska 4 vzorky s 15601 kusmi koristi T. alba. Pred viac ako 50 rokmi boli plamienky početnejšie zastúpené tiež vo vyšších polohách Slovenska, o čom svedčia zbery vývržkov Weisza zo 16 lokalít v Ondavskej vrchovine v rokoch 1945 až 1963, ale tiež súpis údajov z 19. a 20. storočia z vyššie položených kotlín. V 4 vzorkách potravy zo subrecentného obdobia je vyššia diverzita v zastúpení koristi plamienky sprevádzaná nižšou dominanciou $M$. arvalis a početnejším zastúpením myšovitých hlodavcov z rodov Mus a Apodemus. Najstaršia vzorka je z kostola v Žiline-Rudinách, datovaná do 16. storočia.
\end{abstract}

Key words: barn owl, Tyto alba, diet, Slovakia

Ján Obuch, Botanical garden of Comenius University, SK-038 15 Blatnica, Slovakia. E-mail: obuch@rec.uniba.sk.

Štefan Danko, J. Švermu 1, SK-071 01 Michalovce, Slovakia. E-mail: dankostef@gmail.com.

Michal Noga, Raptor Protection of Slovakia, Kuklovská 5, SK-841 04 Bratislava, Slovakia. E-mail: noga@dravce.sk.

Acknowledgements: We wish to thank A. Kürthy for preparation of the map, and two anonymous reviewers and the executive editor for the valuable comments on the text. 


\section{Introduction}

The barn owl (Tyto alba) lives in the vicinity of human beings. Its food residues in the form of pellets are available in buildings. The skulls of mammals are relatively well preserved in them and easily determined. For these reasons more work has been published about the barn owl's food than any other species of owls. However, these works often contain only data on the mammals found in the residues. These are used in faunistic works, e.g., of Erfurth \& Stubbe 1986 in Germany or Pucek \& Raczyński 1983 in Poland, or with statistical analyses, e.g. Libois 1984. The first collections from the territory of Slovakia were processed by foreign authors: Schaefer 1933, Balát 1956 and Schmidt \& Štollmann 1972. Later, we processed data from several regions, e.g. Obuch 1982, 1995, 1998, 2000. Data from students' works are also evaluated: Darolová 1976, Noga 2005 and Latková 2007, which were used during the mapping of the occurrence of mammals in Slovakia (Krištofík \& Danko 2012). Unpublished data from the analysis of owl pel- lets were also included in this atlas. We processed many of the collections of M. Sárossy, which he obtained when mapping the occurrence of $T$. alba in some areas of south Slovakia (Sárossy 1999a, b, c). In the work we also summarize recent published and unpublished data on the food of T. alba from individual localities, evaluated in modified tables according to regions. We compare the summary data with samples from the subrecent period.

The main aim of the work is the preservation of basic data from individual localities for the future, because the declining trend of T. alba and changes in the make up of fauna in agrarian landscapes is striking.

\section{Materials and methods}

In addition to published data in the table overviews, we also present the results of our own analysis of the food residues of $T$. alba. Recent material comes from pellets or from nest linings. By decomposition of organic parts in $5 \% \mathrm{NaOH}$ and rinsing in water we obtained osteolo-

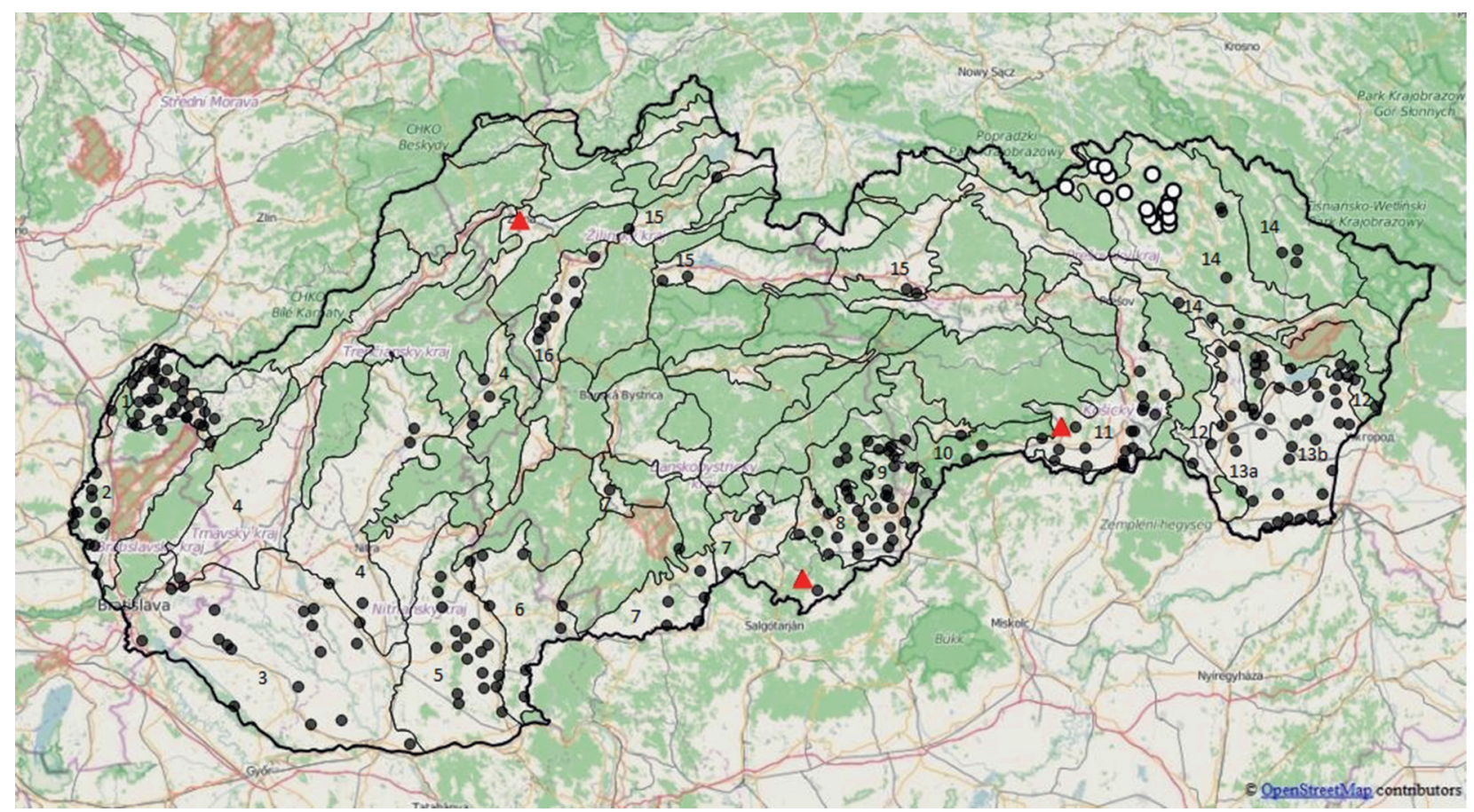

Fig. 1. Position of collection localities with samples of food of Tyto alba. Explanations: solid circle - recent localities, empty circle collections of T. Weisz from 1945-1961, red triangle - subrecent sites. The boundaries of the herein considered territorial units are marked with a black line.

Obr. 1. Poloha zberových lokalít so vzorkami potravy Tyto alba. Vysvetlivky: plný krúžok - recentné lokality, prázdny krúžok - zbery T. Weisza z rokov 1945 - 1961, červený trojuholník - subrecentné náleziská. Hranice tu uvažovaných územných celkov sú vyznačené čiernou čiarou. 
gical material, from which we sorted out for determination the maxilla and mandubula of mammals; the beaks, humerus, metacarpus and tarsometatarsus bones of birds; the os ilium of frogs; the maxilla and mandibula of reptiles; and the heads and some other parts of invertebrates. We determine the abundance of the species in the sample from the most numerous determined body parts. We consider the most abundant species in the sample as the dominant species, and species with abundance over $2 \%$ as subdominant. We use the synonym Apodemus microps, Kratochvíl \& Rosický (1952), for the species described from the Košická kotlina Basin, which has a smaller maxilla size than the nominal species Apodemus uralensis described from Russia. Instead of the genus name, we use the name of the subgenus for the species Terricola (Microtus) subterraneus. The species Mus spicilegus was differentiated from $M$. musculus only in the part of the sample in the Podunajská nížina Lowland and the Východoslovenská nížina Lowland, where it was confirmed by trapping (Krištofík \& Danko 2012). Because all individuals from Mus musculus cannot be differentiated, but we assume that this is the species involved, we introduce the term Mus cf. musculus. The abundance of samples at some localities in the table appendices (Appendix 1-17) is the summary of the results of several collections. An overview of the localities is presented in the table appendix (Appendix 18) and on the map of Slovakia, with geographical units taken from the document of Mazúr \& Lukniš (1980). In the appendix we also present the numbers of the orographic units according to the Databank of Slovak Fauna. We do not present works in which only mammals were determined (e.g. Tirinda 1993), or in which the results are untrustworthy (e.g. Sanitár 2001). We considered samples more than 50 years old as subrecent. For setting the boundary of what is no longer contemporary, but older, we set the boundary of changes which occurred in Slovakia in consequence of socialist collectivization of agriculture.

In the modified tables the samples are arranged according to the similarity of the species spectra. The order of the species is set so that + marked differences from the mean (MDFM, Obuch 2001) are assigned to blocks which are bordered in the tables by a solid line. The calculation of plus and minus MDFM values in the contingency table come from calculation of the $\chi^{2}$ values. The similarity of the samples in the set are not tested as a whole, but species whose abundance in the sample significantly differentiate from the mean (sum- mary) values are ascertained. The measure of the marked difference is derived from geometrical progression of the parameters of the basic linear boundary axis: 1.2 (coefficient) and 4 (constant). The more abundant species without significant marked differences from the mean are given under the dotted line in the tables. They are arranged according to declining total abundance. In the last line of the tables, indexes of diversity H', calculated according to Shannon \& Weaver (1949), are given. Less abundant species and inexactly determined taxons are given under the tables (e.g. Apodemus sp., Passeriformes). We made the calculations of the marked differences from the mean (MDFM) and design of the modified tables using the computer program Zber (Šipöcz 2004).

\section{Results and discussion}

$\mathrm{R}$ e c e n t d i e t

We completed data on the diet of $T$. alba on the basis of determination of osteological residues from pellets for the period of the last 50 years. We analyzed material from 251 localities in 16 territorial units (Tab. 1). Recent samples are mainly from the southern lowland areas (Fig. 1). Collections of food residues from the central Považie and Pohronie regions are mainly absent, although Sárossy (1999c) presents the occurrence of $T$. alba from these parts of Slovakia at the end of the $20^{\text {th }}$ century. The summary represents 119,231 pieces of prey from 47 species of mammals (Mammalia, 95.7\%), 58 species of birds (Aves, 3.9\%) with a small representation of amphibians and reptiles (Amphibia and Reptilia, $0.2 \%$ ) and invertebrates (Invertebrata, 0.2\%). The obtaining of diet is limited with $T$. alba to synanthropic environments and to the surrounding agricultural landscape, and the centre of its distribution is at present concentrated mainly in the southern parts of Slovakia. In this environment the main prey is the common vole (Microtus arvalis, 59.6\%). Supplementary prey are the murids (Muridae): Mus musculus (5.6\%), Micromys minutus (2.2\%), Apodemus microps (2.2\%), A. flavicollis $(2.0 \%)$, A. sylvaticus (1.6\%) and A. agrarius (1.5\%); the shrews (Soricidae): Sorex araneus (6.2\%), S. minutus $(2.4 \%)$, Crocidura leucodon (4.8\%) and C. suaveolens (2.8\%); and the house sparrow (Passer domesticus, $2.9 \%$ ). In the higher located Turčianská kotlina Basin the species $M$. arvalis (74.3\%) has a higher domination and instead of the white-tooth shrew, the water shrews - Neomys anomalus $(2.8 \%)$ and $N$. fodiens $(1.3 \%)$ - are more abundantly represented. The species 
Tab. 1. Comparison of recent food of Tyto alba from 16 areas of Slovakia. Numerical values in the Table are presented in absolute value; positive and negative deviations $(1+, 2+$, and 1-, 2-) are a marked differences from the mean (Obuch 2001) within a respective species, across locations. For more details see Methods. The diversity index $\mathrm{H}^{\prime}$ is used, calculated according to the work of Shannon \& Weaver (1949).

Tab. 1. Porovnanie recentnej potravy Tyto alba zo 16 oblastí Slovenska. Číselné hodnoty v tabul'ke sú uvedené v absolútnych hodnodnotách, kladné a záporné odchýlky (1+, 2+ a 1-, 2-) sú významné odchýlky od priemeru (Obuch 2001) v rámci toho istého druhu, naprieč lokalitami. Pre viac informácii pozri Metodiku. Použitý je index diverzity H', vypočítaný podla práce Shannon \& Weaver (1949).

\begin{tabular}{|c|c|c|c|c|c|c|c|c|c|c|c|c|c|c|c|c|}
\hline \multirow{3}{*}{$\begin{array}{l}\text { localities / lokality } \\
\text { taxa / taxón } \\
\text { Microtus arvalis }\end{array}$} & & \multicolumn{2}{|c|}{16} & \multicolumn{2}{|r|}{9} & \multicolumn{2}{|r|}{10} & \multicolumn{2}{|r|}{15} & \multicolumn{2}{|c|}{14} & \multicolumn{2}{|r|}{12} & \multicolumn{2}{|c|}{11} & 8 \\
\hline & $\mathrm{n}$ & $1+$ & 4705 & $1-$ & 2143 & & 1641 & & 850 & $1-$ & 466 & & 3962 & & 1976 & 6218 \\
\hline & $\%$ & & 74.32 & & 40.91 & & 45.80 & & 66.20 & & 35.25 & & 52.57 & & 54.65 & 54.41 \\
\hline Myotis myotis & & $1+$ & 62 & & 589 & $1-$ & 8 & & 7 & $1-$ & 2 & $2-$ & 15 & $2-$ & 3 & $1-$ \\
\hline Apus apus & & $2+$ & 24 & $2+$ & 18 & & 2 & & & & & & 1 & & & 2 \\
\hline Arvicola amphibius & & $1+$ & 20 & $2+$ & 38 & $1+$ & 12 & $2+$ & 14 & & 2 & & 13 & & 7 & 16 \\
\hline Neomys anomalus & & $2+$ & 176 & & 42 & $1+$ & 46 & $2+$ & 44 & $1+$ & 19 & $1+$ & 82 & $1-$ & 14 & $1+119$ \\
\hline Neomys fodiens & & $3+$ & 80 & & 16 & & 7 & $1+$ & 11 & $1+$ & 9 & & 15 & & 10 & $2-$ \\
\hline Apodemus sylvaticus & & $1+$ & 182 & & 70 & $1+$ & 82 & $1+$ & 35 & & 21 & 3- & 14 & & 49 & $1-\quad 135$ \\
\hline Phoenicurus ochruros & & $1+$ & 29 & & 12 & $1+$ & 23 & & 1 & & & $1-$ & 3 & & 4 & $1-$ \\
\hline Myotis blythii & & & 4 & $3+$ & 26 & & 2 & & & & & & 5 & & 1 & 1 \\
\hline Nyctalus noctula & & & 1 & $1+$ & 6 & & & & & & 2 & & 3 & & & 7 \\
\hline Muscardinus avellanarius & & $1-$ & 0 & $2+$ & 20 & $2+$ & 15 & & & & 2 & & 4 & & 3 & 10 \\
\hline Crocidura leucodon & & $6-$ & 1 & $1+$ & 389 & $1+$ & 321 & $3-$ & 8 & $1+$ & 114 & $1+$ & 657 & & 146 & 639 \\
\hline Crocidura suaveolens & & $2-$ & 49 & $1+$ & 267 & $1+$ & 141 & $2-$ & 10 & & 40 & $1-$ & 172 & $1-$ & 73 & $1+466$ \\
\hline Apodemus flavicollis & & & 105 & $3+$ & 513 & $3+$ & 381 & $2-$ & 5 & $2+$ & 79 & $1-$ & 71 & $1+$ & 96 & $1-\quad 148$ \\
\hline Apodemus agrarius & & $5-$ & 1 & $1+$ & 128 & $2+$ & 154 & $2-$ & 3 & $2+$ & 65 & $1+$ & 266 & $1+$ & 86 & $1+229$ \\
\hline Micromys minutus & & $1-$ & 98 & & 118 & $1+$ & 102 & $2-$ & 3 & $2-$ & 6 & & 185 & $1+$ & 138 & $1+430$ \\
\hline Hirundo rustica & & & 11 & & 11 & $2+$ & 25 & $1+$ & 8 & & & $2-$ & 1 & & 5 & $1-$ \\
\hline Microtus agrestis & & & 1 & & 3 & $1+$ & 6 & & & & 3 & & 2 & & & \\
\hline Coleoptera & & $1-$ & 2 & $1+$ & 14 & & 8 & $1+$ & 10 & & & $2-$ & 0 & & 9 & $1-$ \\
\hline Mus cf. musculus & & & 392 & $1-$ & 144 & $1-$ & 107 & $1+$ & 176 & $2+$ & 253 & $1+$ & 594 & $1+$ & 290 & 1- 492 \\
\hline Clethrionomys glareolus & & $2-$ & 2 & & 23 & & 7 & $1-$ & 0 & $1+$ & 15 & $1-$ & 11 & & 8 & 3- \\
\hline Gryllotalpa gryllotalpa & & & & & 1 & & & & & $2+$ & 11 & & 1 & $1+$ & 7 & 3 \\
\hline Passer domesticus & & $1-$ & 138 & $1-$ & 84 & & 88 & 3- & 3 & $3-$ & 2 & $1+$ & 326 & & 128 & 381 \\
\hline Passer montanus & & $1-$ & 3 & & 6 & & 2 & & & & & $1+$ & 21 & & 9 & $1+$ \\
\hline Pelobates fuscus & & $1-$ & 0 & $1-$ & 0 & & 1 & & & & & $1-$ & 0 & $1+$ & 15 & $1-$ \\
\hline Terricola subterraneus & & $2-$ & 1 & $1-$ & 10 & & 13 & & 2 & & 5 & & 26 & $1+$ & 24 & 47 \\
\hline Talpa europaea & & & 5 & & & & 1 & & 2 & & 1 & & 4 & $1+$ & 9 & 6 \\
\hline Alauda arvensis & & & 3 & & 2 & & & & 1 & & & & 4 & $1+$ & 6 & 8 \\
\hline Eptesicus serotinus & & & 1 & & 1 & & 1 & & & & 4 & & 2 & & 3 & $1+$ \\
\hline Apodemus microps & & $6-$ & 0 & $3-$ & 17 & $1-$ & 43 & & 29 & $2-$ & 3 & $2-$ & 40 & & 86 & $1+584$ \\
\hline Sorex minutus & & $2-$ & 54 & & 133 & $1+$ & 109 & 3- & 3 & $2-$ & 6 & $1-$ & 120 & & 88 & $1-\quad 222$ \\
\hline Sorex araneus & & $2-$ & 113 & & 341 & $1-$ & 169 & $2-$ & 25 & & 79 & & 425 & & 209 & 806 \\
\hline Hymenoptera & & & & & & & & & & & & & & & & \\
\hline Poecile montanus & & & & & & & 1 & & & & & & & & & \\
\hline Delichon urbica & & & 6 & & 2 & & 3 & & & & & & & & & 5 \\
\hline Motacilla alba & & & 3 & & 1 & & 1 & & & & & & & & & \\
\hline Erithacus rubecula & & & & & & & & & 1 & & & & & & & 1 \\
\hline Parus major & & & 1 & & 3 & & 1 & & & & & & 6 & & 2 & $1-$ \\
\hline Fringilla coelebs & & & & & & & 1 & & & & & & & & & \\
\hline Rattus norvegicus & & 4- & 1 & $1-$ & 14 & $2-$ & 7 & $1-$ & 1 & $1-$ & 4 & & 50 & $2-$ & 8 & 99 \\
\hline Rana arvalis & & & & & & & & & & & & & & & 1 & \\
\hline Pelophylax cf.esculentus & & & & & 3 & & 2 & & & & & & & & 2 & 4 \\
\hline Melolontha melolontha & & & & & & & & & & & & & & & & \\
\hline Streptopelia decaocto & & & & & & & & & & & & & & & & 1 \\
\hline Cricetus cricetus & & & & & & & & & & & & & 1 & & 3 & \\
\hline Mus spicilegus & & $3-$ & 0 & $3-$ & 0 & $2-$ & 0 & $1-$ & 0 & $1-$ & 0 & 3- & 0 & $2-$ & 0 & 4- \\
\hline Columba livia dom. & & & & & 2 & & 1 & & & & & & & & 1 & 2 \\
\hline Carduelis chloris & & & 2 & & & & 1 & & & & & & & & & 2 \\
\hline Sturnus vulgaris & & & 3 & & & & & & & & & & & & & \\
\hline Plecotus austriacus & & & 3 & & & & & & & & & & 2 & & 1 & 2 \\
\hline Coturnix coturnix & & & & & 1 & & & & & & & & 1 & & & \\
\hline Rana temporaria & & & 4 & & 2 & & 1 & & & & & & 1 & & 2 & 1 \\
\hline Emberiza citrinella & & & & & 1 & & & & & & & & & & 3 & 1 \\
\hline Mammalia & & & 6090 & & 5064 & & 3416 & & 1258 & & 1308 & & 7065 & & 3410 & 10,920 \\
\hline Aves & & & 235 & 1- & 153 & & 155 & $2-$ & 16 & 4- & 2 & $1+$ & 449 & & 169 & 481 \\
\hline Amphibia, Reptilia & & 1- & 4 & & 5 & & 4 & & 0 & & 1 & $1+$ & 21 & $1+$ & 21 & 17 \\
\hline Invertebrata & & $1-$ & 2 & $1+$ & 16 & & 8 & $1+$ & 10 & $1+$ & 11 & $2-$ & 1 & $1+$ & 16 & 1- \\
\hline $\bar{\Sigma}$ & & & 6331 & & 5238 & & 3583 & & 1284 & & 1322 & & 7536 & & 3616 & 11,428 \\
\hline $\mathrm{H}^{\prime}$ & & & 1.24 & & 2.21 & & 2.14 & & 1.40 & & 2.14 & & 1.90 & & 1.95 & 1.92 \\
\hline
\end{tabular}


Areas / oblasti: 16 - Turčianska kotlina Basin, 9 - Revúcka vrchovina Upland, 10 - Slovenský kras Mts, 15 - Oravská, Liptovská and Popradská kotlina Basin, 14 - Ondavská and Laborecká vrchovina Upland and Beskydské predhorie Foothills, 12 Východoslovenská pahorkatina Hills, 11 - Košická kotlina Basin, 8 - Rimavská kotlina Basin, 7 - Cerová vrchovina Upland, Lučenská and Ipel'ská kotlina Basin, 1 - Chvojnická pahorkatina Hills, 2 - Borská nížina Lowland,13 - Východoslovenská rovina Plain, 5 - Hronská pahorkatina Hills, 4 - Trnavská and Nitrianska pahorkatina Hills and Hornonitrianska kotlina Basin, 3 Podunajská rovina Plain, 6 - Ipel'ská pahorkatina Hills.

\begin{tabular}{|c|c|c|c|c|c|c|c|c|c|c|c|}
\hline & 7 & 1 & 2 & 13 & 5 & 4 & 6 & & 3 & $\Sigma$ & $\%$ \\
\hline \multirow[t]{2}{*}{$\overline{1-}$} & 1384 & 6606 & 8593 & 11166 & 13220 & 1282 & 1716 & & 5102 & 71,030 & 59.57 \\
\hline & 38.69 & 66.56 & 61.93 & 55.87 & 69.92 & 62.81 & 53.48 & & 68.94 & & \\
\hline \multirow[t]{2}{*}{ 3- } & 1 & 4- & $5-$ & 4- & 4- & $2-$ & $2-$ & $4-$ & 0 & 726 & 0.61 \\
\hline & & $1-$ & 3 & $2-$ & $1-$ & & & & & 51 & 0.04 \\
\hline $1+$ & 15 & $1-$ & $1-$ & 31 & $2-$ & & 10 & $2-$ & 0 & 199 & 0.17 \\
\hline$\underline{2+}$ & 101 & 33 & $3-$ & 3- & 48 & 14 & $2-$ & $3-$ & 2 & 772 & 0.65 \\
\hline $1-$ & 2 & 15 & $1+\quad 39$ & $1-$ & 3- & 3 & 4 & $2-$ & 0 & 242 & 0.20 \\
\hline $1+$ & 90 & $1+220$ & $1+461$ & 3- & 309 & 41 & 47 & & 122 & 1922 & 1.61 \\
\hline \multirow[t]{5}{*}{$1+$} & 20 & $1+30$ & 19 & $2-$ & 27 & $1+14$ & 7 & & 12 & 219 & 0.18 \\
\hline & & & $1-$ & $1-$ & $1-$ & & 1 & & & 42 & 0.04 \\
\hline & & & 1 & 8 & 2 & 1 & & & & 31 & 0.03 \\
\hline & 4 & $1-$ & $1-$ & 10 & 15 & & 2 & $1-$ & 0 & 90 & 0.08 \\
\hline & 149 & 1- 364 & 610 & 852 & 744 & 101 & $1+257$ & & 339 & 5691 & 4.77 \\
\hline $1+$ & 187 & $1-\quad 217$ & 435 & 347 & 421 & $1+107$ & $2+\quad 225$ & & 217 & 3374 & 2.83 \\
\hline $1+$ & 94 & $1-\quad 120$ & 95 & 190 & 347 & $2-\quad 11$ & 36 & $2-$ & 34 & 2325 & 1.95 \\
\hline $3-$ & 6 & 6- & $6-$ & $2+806$ & 6- & 3- & 4- & 5- & 0 & 1745 & 1.46 \\
\hline$\overline{1+}$ & 193 & $1-\quad 130$ & $1-\quad 179$ & $1+699$ & 172 & 45 & 44 & $2-$ & 49 & 2591 & 2.17 \\
\hline \multirow[t]{3}{*}{$2+$} & 25 & 12 & 20 & $1-$ & $1+$ & 8 & 5 & & 11 & 229 & 0.19 \\
\hline & & & 1 & 2 & 1 & & 1 & & 2 & 22 & 0.02 \\
\hline & 4 & $2-$ & $2+\quad 50$ & 21 & 16 & & & $2-$ & 0 & 140 & 0.12 \\
\hline \multirow[t]{3}{*}{$1+$} & 279 & $1-\quad 330$ & 730 & 1042 & 1192 & $1-$ & 146 & & 383 & 6637 & 5.57 \\
\hline & 8 & 39 & $2+\quad 155$ & $1-$ & $1-\quad 37$ & 4 & $1-$ & & 29 & 377 & 0.32 \\
\hline & & & & 2 & 4 & & & & & 29 & 0.02 \\
\hline \multirow[t]{8}{*}{$1+$} & 140 & 324 & 399 & $1+704$ & 312 & $1+116$ & $1+130$ & & 198 & 3473 & 2.91 \\
\hline & 4 & $2-$ & 18 & 32 & 27 & 2 & 4 & & 6 & 163 & 0.14 \\
\hline & 5 & $2-$ & $1-$ & $2+$ & $2-$ & & $2+$ & $1-$ & 0 & 101 & 0.08 \\
\hline & 10 & 3- & 21 & $1+\quad 159$ & 37 & 3 & $1+$ & $3-$ & 1 & 378 & 0.32 \\
\hline & 1 & 4 & 3 & 7 & 6 & 1 & 1 & & & 51 & 0.04 \\
\hline & 2 & & 7 & 7 & 5 & 1 & & & 2 & 48 & 0.04 \\
\hline & & & & & 1 & & 1 & & & 21 & 0.02 \\
\hline & 83 & 260 & 85 & $1+629$ & $1+605$ & $1-$ & 36 & & 146 & 2665 & 2.24 \\
\hline $2+$ & 266 & $1+310$ & $1+447$ & $1+\quad 583$ & 185 & 46 & 83 & & 175 & 2830 & 2.37 \\
\hline $1+$ & 432 & $1+781$ & $1+1324$ & $1+1713$ & 333 & $1-$ & 181 & $1-$ & 322 & 7350 & 6.16 \\
\hline \multirow[t]{13}{*}{$\underline{3+}$} & 29 & & & $1-\quad 0$ & $1-$ & & & & & 29 & 0.02 \\
\hline & & $1+$ & & & & & & & & 6 & 0.005 \\
\hline & 1 & 6 & 12 & 3 & $1-$ & 3 & 1 & & & 44 & 0.04 \\
\hline & & & $1+$ & 1 & 1 & & & & & 13 & 0.01 \\
\hline & & 4 & $1+$ & 2 & 4 & & 1 & & & 20 & 0.02 \\
\hline & & 2 & $1+$ & 13 & 8 & & & & 3 & 66 & 0.06 \\
\hline & & 21 & $2+$ & 3 & 1 & & & & & 21 & 0.02 \\
\hline & 26 & 80 & $2-\quad 2.31$ & $1+189$ & $1+293$ & $1+33$ & 16 & & 58 & 910 & 0.76 \\
\hline & & & & $1+$ & & & & & & 8 & 0.007 \\
\hline & 4 & $1-$ & 6 & $1+$ & $1-$ & & & & 2 & 50 & 0.04 \\
\hline & & & & $1+$ & & & & & & 9 & 0.008 \\
\hline & & & & $1+$ & 4 & 1 & & & & 13 & 0.01 \\
\hline & & & & 8 & $1+$ & & & & & 22 & 0.02 \\
\hline \multirow[t]{9}{*}{$2-$} & 0 & 4- & 4- & $3-$ & $2+\quad 327$ & 1- & $1-$ & $2+$ & 101 & 439 & 0.37 \\
\hline & & & & 1 & $1+$ & & & $1+$ & 6 & 22 & 0.02 \\
\hline & & & 3 & 2 & 4 & & & & & 14 & 0.01 \\
\hline & & 1 & 1 & 3 & 6 & & & & & 14 & 0.01 \\
\hline & 2 & 1 & 2 & & & & & & & 13 & 0.01 \\
\hline & 1 & & & 5 & 2 & & & & 1 & 11 & 0.009 \\
\hline & & & & & & & & & & 11 & 0.009 \\
\hline & & & 2 & 1 & 1 & & 1 & & & 10 & 0.008 \\
\hline & 3336 & 9530 & 13,250 & 19,027 & 18,390 & 1896 & 3001 & & 7153 & 114,114 & 95.71 \\
\hline \multirow[t]{2}{*}{$1+$} & 198 & 395 & 568 & 844 & 491 & $1+145$ & 152 & & 246 & 4699 & 3.94 \\
\hline & 9 & 3- & $1-$ & $1+$ & 2- & 0 & $2+$ & 2- & 2 & 207 & 0.17 \\
\hline \multirow[t]{3}{*}{$\underline{2+}$} & 34 & 3- & 50 & 32 & 21 & 0 & $1-$ & $2-$ & 0 & 211 & 0.18 \\
\hline & 3577 & 9925 & 13,876 & 19,986 & 18,908 & 2041 & 3179 & & 7401 & 119,231 & 100.00 \\
\hline & 2.25 & 1.46 & 1.60 & 1.85 & 1.41 & 1.58 & 1.84 & & 1.40 & 1.82 & \\
\hline
\end{tabular}


diversity of the diet of $T$. alba is here at its lowest $\left(\mathrm{H}^{\prime}=\right.$ 1.24). Some barn owls focused on the hunting of bats. For example, in the church in Ratkova (Revúcka vrchovina Upland) Chiroptera made up $35.2 \%$ of prey in one observed individual of T. alba. Species diversity of prey in the scope of the compared 16 territorial units of Slovakia is the highest in the more rugged territory of the Revúcka vrchovina Upland, the Cerová vrchovina Upland and the Slovenský kras Mts, and lower in the more uniform agricultural large-surfaces of the managed lowlands and basins. With the exception of distribution of the species $A$. agrarius in eastern Slovakia, it is more difficult in other species to characterise specific geographical regularities. This partially involves differences in the intensity of the anthropic use of the land, but a definite factor is also the capability of individuals or breeding pairs of these owls to favour some prey from species of rodents, insectivores or passerines. Deviations in the represented dominant species $M$. arvalis are associated with its population dynamic. With large samples from several years the value of dominance is closer to the average than with the collections from years of gradations or population minimums.

\section{Chvojnická pahorkatina Hills}

Latková (2007) devoted herself to more detailed research of the T. alba population in the Upper Záhorie region in the years 2002 to 2006 (Appendix 1). Food residues were analysed from 34 localities. The dominant common vole ( $M$. arvalis; average representation $66.6 \%$, minimally $39.2 \%$, maximally $93.2 \%$ ) had a significantly higher abundance at 3 localities, while the species Sorex araneus (7.9\%), Crocidura leucodon (3.7\%) and Passer domesticus were subdominant at 6 localities. The Muridae had a more balanced proportionate representation in the samples: Mus cf. musculus (3.3\%), Apodemus microps $(2.6 \%)$ and Apodemus sylvaticus $(2.2 \%)$. Upon checking 28 breeding locations listed by Latková, Vongrej (2015) found only 2 breeding pairs. A rapid decline has occurred in the last 2 to 5 years.

\section{Borská nižina Lowland}

Increased attention was paid to the collection of food residues of T. alba in the 1990s (Appendix 2). Noga (2005) summarized the results of analyses. The species M. arvalis (average of $61.5 \%$, minimum $25.4 \%$, maximum $75.6 \%$ ) predominates. The Soricidae: $S$. araneus (9.5\%), S. minutus (3.2\%), C. leucodon (4.4\%) and Crocidura suaveolens (3.1\%); the sparrow P. domesticus (3.6\%) and the Muridae: M. cf. musculus (5.2\%) and A. sylvaticus (3.3\%) are more abundantly represented. The samples from Jakubova, with 8 more abundant species, and from Plavecký Štvrtok, with a higher abundance of 7 species, differ the most from the average.

\section{Podunajská rovina Plain}

Tirinda (1986) published recent data on the representation of mammals in the food of $T$. alba from this area. Collections from the 1990s are presented in the Appendix 3. M. arvalis dominates (average 68.9\%, minimum $16.4 \%$, maximum $89.9 \%$ ). The Soricidae: $C$. leucodon (4.6\%), S. araneus (4.4\%), C. suaveolens $(2.9 \%)$ and $S$. minutus $(2.4 \%)$ are represented more abundantly than the Muridae: $M$. cf. musculus (5.2\%), A. microps (2.0\%) and A. sylvaticus (1.6\%). In 3 localities the sparrow $P$. domesticus $(2.7 \%)$ was more abundantly hunted. The highest species diversity of T. alba prey was found in the collections from Dunajská Lužna $\left(\mathrm{H}^{\prime}=\right.$ 2.17). Upon checking 63 sites of the Podunajská nížina Lowland in which $T$. alba was observed in the past, Veselovský (2014) did not find a single living owl.

\section{Trnavská and Nitrianska pahorkatina Hills and the Hornonitrianska kotlina Basin}

Although much of the data on the occurrence of $T$. alba from the listed orographic units before the year 2000 is from Sárossy (Sárossy 1999c), a part of whose collections were processed by Sanitár (2001), reliable analysis of the food residues of T. alba were made only from 10 localities (Appendix 4). The proportional representation of $M$. arvalis (average $62.8 \%$, minimum $42.3 \%$, maximum $80.0 \%$ ) and several subdominant species: $S$. araneus $(4.8 \%), M$. musculus $(4.3 \%)$ and $A$. sylvaticus $(2.0 \%)$ is relative balanced in the samples. Greater differences are in the representation of the white-toothed shrews C. suaveolens $(2.2 \%)$ and C. leucodon $(2.0 \%)$ and the sparrow $P$. domesticus (5.7\%), which was hunted more abundantly in 2 localities.

\section{Ipel'ská pahorkatina Hills}

Beyond the older published works (Darolová 1976, Vondráček \& Hošek 1984) the unpublished collections of M. Sárossy are also given in the Appendix 6. They are distinguished by notable variability in the dominance of $M$. arvalis (average $54.0 \%$, minimum $26.1 \%$, maximum $80.9 \%$ ), but also more abundant representa- 
tion of species of the family Soricidae: C. leucodon $(8.1 \%)$, C. suaveolens $(7.1 \%)$ and $S$. araneus $(2.6 \%)$. The dominance of species of the family Muridae is lower: M. cf. musculus (4.6\%), A. sylvaticus (1.5\%) and M. minutus (1.4\%). In Salka the sparrow P. domesticus $(4.1 \%)$ was more abundantly hunted.

\section{Hronská pahorkatina Hills}

Older analyses of food are from the southern part of the Hronská pahorkatina Hills (Balát 1956, Vondráček \& Hošek 1984). G. Demeter (Obuch 2014) collected larger samples from Tekovské Lužany and the surrounding villages, and M. Sárossy collected food remnants of $T$. $a l b a$ at several localities (Appendix 5). In the residues of food from the nest in the tower of the Reformed Church in Tekovské Lužany the recent occurrence of the southern birch mouse (Sicista subtilis) was confirmed on the territory of Slovakia (Demeter \& Obuch 2004). In the collection of pellets of J. Korñan from Arad the first occurrence of the root vole (Microtus oeconomus) for the territory of the national nature reserve Parížske močiare Marsh (Noga \& Obuch 2004) was determined. The high dominance of $M$. arvalis (average $69.9 \%$, minimum $43.9 \%$, maximum $95.6 \%$ ) and the relatively low species diversity (in 7 samples $\mathrm{H}^{\prime}<1$ ) testifies about a habitat with intensive agriculture production. From the family Muridae the most abundantly represented species are $M$. cf. musculus $(6.3 \%)$ and $A$. microps $(3.2 \%)$, and from the family Soricidae the species C. leucodon (3.9\%) and C. suaveolens $(2.2 \%)$.

\section{South-central Slovakia}

Data from the Lučenská kotlina Basin were published (Obuch \& Uhrin 1997). The Appendix 7 includes samples from 5 orographic units: Pliešovská kotlina Basin, Ostrôžky Mts, Ipel'ská kotlina Basin, Lučenská kotlina Basin and the Cerová vrchovina Upland. The set is distinguished by the low average domination of $M$. arvalis (average 38.7\%, minimum 10.3\%, maximum $72.7 \%)$. The representation of the family Soricidae: $S$. araneus $(12.1 \%), S$. minutus $(7.4 \%)$, C. suaveolens $(5.2 \%)$, C. leucodon $(4.2 \%)$ and $N$. anomalus $(2.8 \%)$ is higher than the species of the family Muridae: $M$. cf. musculus (7.8\%) and M. minutus (5.4\%). At 2 localities the sparrow $P$. domesticus (3.9\%) is more abundantly represented. The collection from the settlement Majša is exceptional with the number of residues of invertebrates from the orders Hymenoptera and Coleoptera.

\section{Rimavská kotlina Basin}

The largest sample is from the church in Rimavské Janovce, where in addition to the listed collections (Darolová 1976, Obuch 1995, Sárossy); Vohralík (in litt.) also collected pellets of $T$. alba. Alongside the dominant common vole $M$. arvalis (average 54.45\%, minimum $19.7 \%$, maximum $65.6 \%$ ) species of the family Soricidae: S. araneus (7.1\%), C. leucodon (5.6\%) and $C$. suaveolens $(4.1 \%)$ are more abundant than those of the family Muridae: A. microps (5.1\%), M. cf. musculus $(4.3 \%)$ and M. minutus (3.8\%) (Appendix 8). The house sparrow $P$. domesticus $(3.3 \%)$ is the most abundantly hunted bird species. Samples of food are distinguished by relatively high species diversity (11 samples have $\mathrm{H}^{\prime}>1.9$ ).

\section{Revúcka vrchovina Upland}

Obuch (2000) surveyed the food of owls in this area in more detail. The rugged hilly terrain is reflected in more differentiated samples of food of $T$. alba. The average dominance of $M$. arvalis (40.9\%) is low, but in 5 localities it is significantly higher (54.6\%-77.3\%) (Appendix 9). At 4 localities the proportional representation of $M$. musculus (average 2.8\%) and $P$. domesticus (average $1.6 \%)$ is higher, and at the higher elevations Lipovec and Nandraž the forest species A. flavicollis (9.8\%) and Clethrionomys glareolus $(0.4 \%)$ are more abundantly represented. The sample from Šivetice with 6 differentiated species has a special character. The collections from Ratková, where the barn owl adapted to hunting bats ( 8 species) and common swifts (Apus apus) flying out of the loft of the church in the centre of the village, are exceptional. Petrželková et al. (2004) state that when hunting the barn owl preferred younger individuals of the species Myotis myotis from a female colony estimated at 4000 individuals (Uhrin et al. 2002).

\section{Slovenský kras Mts}

Obuch (1998) published collections from the 1990s. The localities were found predominately in deep valleys bounded by the steep forested slopes of the karstic plateau. The dominance of $M$. arvalis (average $45.8 \%$, minimum $19.8 \%$, maximum $86.0 \%$ ) varies significantly (Appendix 10). From the family Muridae the species with the highest abundance are A. flavicollis (10.6\%) and $A$. agrarius (4.3\%), from the family Soricidae $C$. leucodon $(9.0 \%)$ and $S$. araneus (4.7\%). Samples of food of T. alba in half of the localities (4 localities) are characterized by high species diversity ( $\left.\mathrm{H}^{\prime}>2\right)$. 


\section{Košická kotlina Basin}

Danko \& Štollmann (1977) published the first results of collections of pellets of T. alba from the southern part of the Košická kotlina Basin. A systematic collection of pellets from the church was carried out in the 1990s (Obuch \& Matis 1998). In part of the samples the domination of $M$. arvalis is above average (average $54.6 \%$, minimum 26.7\%, maximum 91.9\%) (Appendix 11). From the family Muridae the species $M$. cf. musculus $(8.0 \%)$ and $M$. minutus $(3.8 \%)$ are more abundantly represented, and from the family Soricidae $S$. araneus $(5.8 \%)$ and C. leucodon (4.1\%), and from the birds the sparrow P. domesticus (3.5\%). In addition 5 species of frogs (Amphibia, 0.6\%) were determined.

\section{Východoslovenská pahorkatina Hills}

The majority of the collections of T. alba pellets come from the end of the $20^{\text {th }}$ century. Anderra et al. (1982) collected them in the foothills of the Vihorlat Mts. The domination of $M$. arvalis (average $52.6 \%$, minimum $0 \%$, maximum $83.3 \%$ ) varied considerably (Appendix 12). In the large part of the samples the species of the sub-genus Sylvaemus (Apodemus sp. $=4.3 \%$ ) were not differentiated; therefore the abundances of the species A. flavicollis, A. sylvaticus and A. microps is underestimated. From the species of the family Soricidae the most abundantly represented species are $C$. leucodon $(8.7 \%)$ and $S$. araneus $(5.6 \%)$. The house sparrow P. domesticus (4.3\%) was most hunted in Zalužice.

\section{Východoslovenská rovina Plain}

Food samples of $T$. alba from the Východoslovenská rovina Plain were obtained from 34 localities by systematic survey. We present the results in 2 tables: 16 localities from the western part (Appendix 13a) and 18 localities from the eastern part (Appendix 13b). The dominance of $M$. arvalis (average $55.9 \%$ ) on average does not differ between the areas, but in 7 localities it is significantly above average $(68 \%-82 \%)$. In both areas the species $S$. araneus $(8.6 \%)$ and $C$. leucodon $(4.3 \%)$ are the most represented from the family Soricidae, and the species $M$. cf. musculus (5.2\%) and A. agrarius (4.0\%) from the family Muridae. The house sparrow $P$. domesticus $(3.5 \%)$ was the most hunted in Zemplínske Hradište. The highest species diversity is in the samples from Biel $\left(\mathrm{H}^{\prime}=2.24\right)$ with multiple representation of 3 species of frogs (Amphibia, 3.4\%) and beetles (Coleoptera, 2.3\%).

\section{North-eastern Slovakia}

Recent samples of the diet of T. alba are from 4 localities in the Ondavská vrchovina Upland, 3 localities of the Laborecká vrchovina Upland and 3 localities of the Beskydské predhorie Foothills. The average dominance of $M$. arvalis $(35.2 \%)$ is low and is significantly higher in 3 localities (49.2\%-68.7\%) (Appendix 14). From the family Muridae the species M. musculus (19.1\%) and $A$. agrarius $(4.9 \%)$ have the highest abundance, and from the family Soricidae the species C. leucodon (8.6\%) and $S$. araneus $(6.0 \%)$. Birds and amphibians are only slightly represented in the whole set, and from invertebrates the European mole cricket Gryllotalpa gryllotalpa was more abundant in one locality.

\section{Basins of northern Slovakia}

From 1998 up through 2015 collections from 2 localities in the Popradská kotlina Basin and one each in the Liptovská kotlina Basin and in Orava, were analysed. In Párnica barn owls in 2015 were fed with barnyard chicks (Flajs \& Obuch 2015); we do not list their representation in the food in the table (Appendix 15). The dominance of $M$. arvalis (average $66.2 \%$, minimum $52.3 \%$, maximum $79.3 \%$ ) is high. From the family Muridae the more abundantly represented species are $M$. musculus (13.7\%) and A. sylvaticus (2.7\%), and from the family Soricidae the species $N$. anomalus $(3.4 \%)$ and $S$. araneus $(2.0 \%)$. The proportional representation of birds is low (Aves, 6 species, 1.2\%).

\section{Turčianska kotlina Basin}

Schmidt \& Štollmann (1972) and Obuch (1982, 1991, 2002) present older data on the diet of T. alba in Turčianská kotlina Basin. The dominance of M. arvalis (average $74.3 \%$, minimum $25.8 \%$, maximum $84.9 \%$ ) is high (Appendix 16). The sample from Socovce is exceptional with its high abundance of the species $M$. musculus, M. minutus and P. domesticus. In Necpaly $T$. alba hunted an increased number of bats (Chiroptera, 6 species) and synanthropic species of birds. A large colony of bats was also in the nave of the church in Turany, but $T$. alba, which bred in the church tower, hunted them only in a small number (Obuch \& Kadlečík 1997). From the family Muridae the most represented species are M. musculus (6.2\%) and A. sylvaticus (2.9\%), and from the family Soricidae the species $N$. anomalus $(2.8 \%)$ and $S$. araneus $(1.8 \%)$. 
$\mathrm{Sub} \mathrm{r}$ e ce n t d i e t

In 4 subrecent samples of diet of T. alba changes are reflected in the method of using the human landscape, especially in agricultural production (Tab. 2). In the recent period from the mid-1960s large agricultural enterprises with vast areas of parcels for a single crop predominated in Slovakia as well as the use of machinery for ploughing them. The chemical method of protecting plants against damage and weeds predominates, and animal production is concentrated into large complexes with a specialization on one product. A consequence of reducing the diversity of plants and animal production, the diversity of the animals inhabiting the landscape is also lower. On large areas of multiyear feeds and winter crops the common vole (M. arvalis) mainly prospers. In contrast, rodents, with the exception of the species $A$. agrarius, in which a trend of expansion to new territories has been recorded in the recent period, are in decline. Its subrecent occurrence in Šurice and in Žilina, however, indicates that it also inhabited the margins of today's territory in the past.

\section{Šurice}

A sample from cliff hollows at Soví hrad Castle in Surice, located in the Cerová vrchovina Upland, is characterised by high species diversity of prey of $T$. al- $b a\left(\mathrm{H}^{\prime}=2.83\right)$ with a high share of frogs (Amphibia, 5 species) bats (Chiroptera, 6 species) and white-toothed shrews (Crocidura leucodon and $C$. suaveolens). A higher representation of the Miller's water shrew $(N$. anomalus) and the harvest mouse (M. minutus) indicates the occurrence of more extensive wetlands in the past, which have now dried out.

\section{Hatiny}

A sample of the diet of $T$. alba with a high diversity of prey $\left(H^{\prime}=2.28\right)$ from the ceiling of a cave near the Hatiny settlement on the eastern edge of the Slovenský kras Mts pointed to the occurrence of wetlands in the alluvia of the Bodva River. Alongside the high abundance of M. minutus, the species Sicista subtilis and Microtus oeconomus, whose recent occurrence after improvement of the surrounding meadows is not probable, also lived here.

\section{Žilina}

For subrecent samples, a high domination of species of the family Muridae is characteristic, especially M. musculus and the sub-genus Sylvaemus (species A. flavicollis, A. sylvaticus and A. microps). Perhaps it is best to demonstrate these changes by comparing samples from the $16^{\text {th }}$ century from a church in Žilina, Rudiny

Fig. 2. Determination of species of the family Muridae from a subrecent sample from the Church of Saint Stephen the King in Žilina.

Obr. 2. Detrminácia druhov čelade Muridae zo subrecentnej vzorky z Kostola sv. Štefana král'a v Žiline.

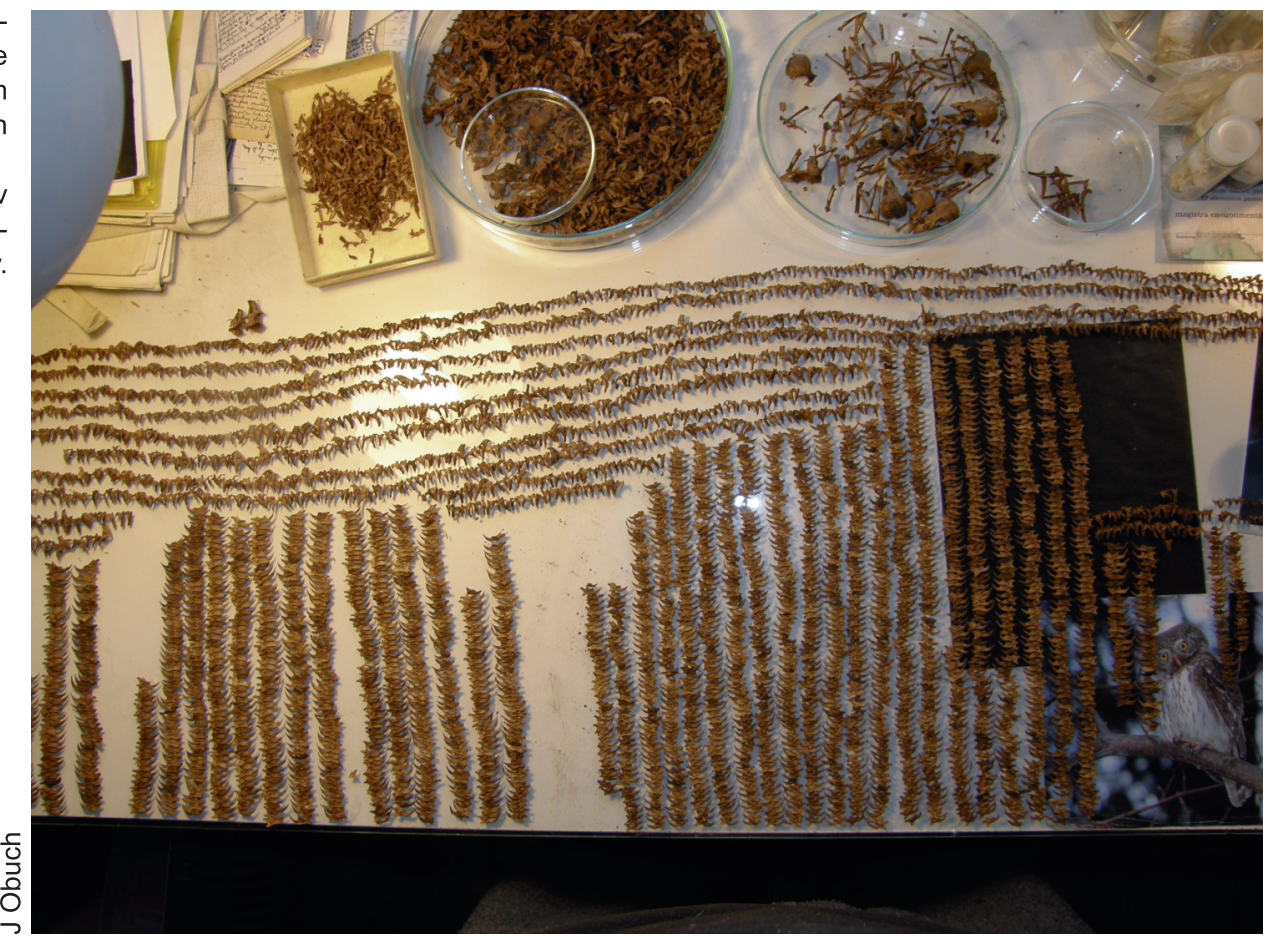


Tab. 2. Comparing the food of Tyto alba according to age of the site. Numerical values in the Table are presented in absolute value; positive and negative deviations (1+, 2+, and 1-, 2-) are a marked differences from the mean (Obuch 2001) within a respective species, across locations. For more details see Methods. The diversity index $\mathrm{H}^{\prime}$ is used, calculated according to the work of Shannon \& Weaver (1949).

Tab. 2. Porovnanie potravy Tyto alba podla veku nálezísk.Číselné hodnoty v tabul'ke sú uvedené v absolútnych hodnodnotách, kladné a záporné odchýlky (1+, 2+ a 1-, 2-) sú významné odchýlky od priemeru (Obuch 2001) v rámci toho istého druhu, naprieč lokalitami. Pre viac informácii pozri Metodiku. Použitý je index diverzity H', vypočítaný podla práce Shannon \& Weaver (1949).

\begin{tabular}{|c|c|c|c|c|c|c|c|c|}
\hline $\begin{array}{l}\text { localities / lokality } \\
\text { taxa / taxón }\end{array}$ & & 1 & 3 & 4 & 2 & 5 & $\sum$ & $\%$ \\
\hline \multirow[t]{2}{*}{ Microtus arvalis } & $\mathrm{n}$ & 71,030 & 2- 182 & $1-821$ & 3897 & 1- 1102 & 77,032 & 57.13 \\
\hline & $\%$ & 59.57 & 19.76 & 27.67 & 51.05 & 27.40 & & \\
\hline Bufo bufo & & 4- & $4+71$ & & 1- & & 71 & 0.05 \\
\hline Limacidae & & $2-$ & $3+20$ & & & & 21 & 0.02 \\
\hline Crocidura leucodon & & 5691 & $2+149$ & 170 & $1-\quad 284$ & 62 & 6356 & 4.71 \\
\hline Crocidura suaveolens & & 3374 & $2+\quad 91$ & 95 & 186 & 59 & 3805 & 2.82 \\
\hline Plecotus austriacus & & 13 & $1+$ & 1 & & & 19 & 0.01 \\
\hline Parus major & & 66 & $1+$ & 2 & $1-$ & & 74 & 0.05 \\
\hline Passer domesticus & & 3473 & $1+$ & 17 & $3-$ & 96 & 3666 & 2.72 \\
\hline Passer montanus & & 163 & $1+$ & 1 & $2-$ & 1 & 171 & 0.13 \\
\hline Bombina sp. & & $1-$ & $1+$ & & & & 7 & 0.005 \\
\hline Pelobates fuscus & & 101 & $1+$ & 3 & $1-$ & & 111 & 0.08 \\
\hline Pelophylax cf. esculentus & & 50 & $1+$ & & & & 57 & 0.04 \\
\hline Neomys anomalus & & 772 & 43 & 15 & $2+155$ & $2+$ & 1074 & 0.80 \\
\hline Rhinolophus hipposideros & & $2-$ & 17 & $1+$ & 4 & & 32 & 0.02 \\
\hline Micromys minutus & & 2591 & 31 & $2+181$ & 23 & 60 & 2886 & 2.14 \\
\hline Muscardinus avellanarius & & 90 & 1 & $2+\quad 22$ & 11 & 3 & 127 & 0.09 \\
\hline Sicista subtilis & & $1-$ & & 12 & & & 15 & 0.01 \\
\hline Pipistrellus pipistrellus & & 7 & & $1+$ & & & 14 & 0.01 \\
\hline Sorex araneus & & 7350 & 45 & $1+388$ & 419 & 43 & 8245 & 6.12 \\
\hline Clethrionomys glareolus & & 377 & 3 & $1+\quad 17$ & 32 & $1-$ & 432 & 0.32 \\
\hline Terricola subterraneus & & 378 & 1 & 28 & $1-$ & 18 & 438 & 0.32 \\
\hline Mus cf. musculus & & $1-\quad 6637$ & 69 & $2+668$ & $1+999$ & $2+1401$ & 9774 & 7.25 \\
\hline Apodemus flavicollis & & 2325 & 25 & $1+140$ & $1+305$ & $1+128$ & 2923 & 2.17 \\
\hline Neomys fodiens & & $1-\quad 242$ & & $1+\quad 26$ & $1+\quad 54$ & $3+103$ & 425 & 0.32 \\
\hline Apodemus microps & & 2665 & 16 & $1+111$ & $2-\quad 71$ & $2+\quad 337$ & 3200 & 2.37 \\
\hline Apodemus agrarius & & 1745 & $2-$ & $1+\quad 88$ & $2+350$ & $1-$ & 2238 & 1.66 \\
\hline Arvicola amphibius & & 199 & 2 & 6 & $2+\quad 57$ & 6 & 270 & 0.20 \\
\hline Nyctalus noctula & & 31 & & & $1+$ & & 45 & 0.03 \\
\hline Eptesicus serotinus & & 21 & 1 & 1 & $1+$ & 1 & 33 & 0.02 \\
\hline Plecotus auritus & & $1-$ & & 2 & $1+$ & & 16 & 0.01 \\
\hline Talpa europaea & & $1-$ & 2 & 5 & $1+$ & $2+$ & 89 & 0.07 \\
\hline Apodemus sylvaticus & & 1922 & 12 & 35 & 147 & $3+\quad 395$ & 2511 & 1.86 \\
\hline Rana temporaria & & $1-$ & 1 & & & $2+$ & 26 & 0.02 \\
\hline Coleoptera & & 140 & & 1 & $2-$ & $1+$ & 157 & 0.12 \\
\hline Hirundo rustica & & 229 & 1 & $1-$ & $2-$ & $1+$ & 244 & 0.18 \\
\hline Coturnix coturnix & & 11 & & & & $1+$ & 16 & 0.01 \\
\hline Rattus norvegicus & & 910 & 2 & $3-$ & 4- & 3- & 912 & 0.68 \\
\hline Mus spicilegus & & 439 & & $2-$ & 3- & $2-$ & 439 & 0.33 \\
\hline Sorex minutus & & 2830 & $2-$ & 77 & 97 & 18 & 3023 & 2.24 \\
\hline Myotis myotis & & 726 & 5 & $2-$ & 38 & 3- & 770 & 0.57 \\
\hline Phoenicurus ochruros & & 219 & & $1-$ & $1-$ & $1-$ & 222 & 0.16 \\
\hline Vespertilio murinus & & $1-$ & 1 & 1 & 1 & 3 & 8 & 0.006 \\
\hline Apus apus & & 51 & 2 & & 1 & & 54 & $0.0 \overline{4}$ \\
\hline Alauda arvensis & & 48 & 1 & & & 4 & 53 & 0.04 \\
\hline Delichon urbica & & 44 & 1 & & & & 45 & 0.03 \\
\hline Myotis blythii & & 42 & & 2 & & & 44 & 0.03 \\
\hline Hymenoptera & & 29 & & & & 1 & 30 & 0.02 \\
\hline Gryllotalpa gryllotalpa & & 29 & & & & & 29 & 0.02 \\
\hline Fringilla coelebs & & 21 & 3 & 1 & & 3 & 28 & 0.02 \\
\hline Microtus agrestis & & 22 & & & 4 & & 26 & 0.02 \\
\hline Columba livia dom. & & 22 & & & & & 22 & 0.02 \\
\hline Cricetus cricetus & & 22 & & & & & 22 & 0.02 \\
\hline Erithacus rubecula & & 20 & & & & 1 & 21 & 0.02 \\
\hline Mammalia & & 114,114 & 1- 714 & 2931 & 7582 & 3906 & 129,247 & 95.86 \\
\hline Aves & & 4699 & 86 & 28 & 46 & 136 & 4995 & 3.70 \\
\hline Amphibia, Reptilia & & 207 & $4+101$ & 7 & 10 & 16 & 341 & 0.25 \\
\hline Invertebrata & & 211 & $2+\quad 20$ & 1- & 2- & $1+$ & 249 & 0.18 \\
\hline $\bar{\Sigma}$ & & 119,231 & 921 & 2967 & 7638 & 4075 & 134,832 & 100.00 \\
\hline $\mathrm{H}^{\prime}$ & & 1.82 & 2.83 & 2.28 & 1.91 & 2.4 & 1.90 & \\
\hline
\end{tabular}


(Fig. 2), with recent diet of T. alba in the neighbouring Turčianská kotlina Basin: in the past the dominance of $M$. arvalis $(19.8 \%)$, which consumes green vegetation, was significantly lower, and in contrast there was a high proportional representation of the seed-eating species M. musculus and from the genus Apodemus, which had access to grain from the harvest in July up through the threshing in the autumn. Many seeds of weeds are also found in and around the fields. At present the harvest together with threshing lasts 2 to 3 weeks and after ploughing under the stubble in August the access of rodents to grain ends. Small poultry farms in village yards are also gradually disappearing. In the sample from Žilina from the $16^{\text {th }}$ century the represented whitetoothed shrew C. leucodon, which recently occurred in the low elevations of Slovakia and is gradually disappearing from mountain basins, was more abundant (Obuch \& Darola 1980).

\section{Ondavská vrchovina Upland: 1945-1961}

At 16 localities of the Ondavská vrchovina Upland, where T. Wiesz collected pellets of T. alba in the years 1945 to 1961, the occurrence of these owls was not confirmed in later years. The material was loaned to us for determinations from the collection of the Šariš $\mathrm{Mu}$ seum in Bardejov. In the results of the analyses (Appendix 17) the domination of $M$. arvalis (average $51.0 \%$, minimun $0 \%$, maximum $61.8 \%$ ) did not differ from the recent period; however, the share of some species of the family Muridae is higher (the species $M$. musculus (13.1\%), A. flavicollis (4.0\%) and A. agrarius $(4.6 \%))$. From the family Soricidae the abundant representation of Miller's water shrew ( $N$. anomalus, $2.0 \%$ ) is characteristic for higher elevated localities, but the share of the species $S$. araneus $(5.5 \%)$ and $C$. leucodon $(3.7 \%)$ is higher. Significant variability in the proportion of representation was determined in the species $S$. araneus, M. musculus, A. flavicollis and A. agrarius.

Uttendörfer (1952) carried out the first summation of data on the diet of T. alba. He presents 77,602 vertebrates and 587 invertebrates from collections from the years 1922 through 1949 from 180 German localities (Germany during the Third Reich, including Silesia and Eastern Prussia). A sample from Lubica near Kežmarok, which was processed by Schaefer (1933), is also included there. He collected pellets in the years 1931 through 1933. He determined 876 pieces of prey, among which were 12 bats and 14 birch mice (Sicista sp.). Data from present-day Poland were used in their Atlas of Mammals (Pucek \& Raczyński 1983). For the needs of the atlas, in 1955-1977 they acquired 958 collections of owl pellets from 735 localities and determined 378,000 small mammals. From this, there were pellets of T. alba in $90 \%$ of the collections. In the Czech Republic, Poprach (2008) presents data from 29 literature sources, a total of 120,026 vertebrates and 185 invertebrates, in a monograph on $T$. alba. The collections are from the years 1941 through 2004. Schmidt (1973) presented data on the diet of T. alba from Europe. Schmidt \& Sipos (1971) corroborated the occurrence of the species

\section{Tab. 2. Continuation}

Tab. 2. Pokračovanie

Samples / vzorky: 1 - Slovakia, recent (collections from 1965 - 2015), 3 - Šurice, Soví hrad Castle, subrecent, 12.11.1997, 4 Hatiny, cave., subrecent, 25.9.1977 (Obuch 1992a), 2 - Ondavská vrchovina Upland, 1945-1963, leg. Weisz, 5 - Žilina, Rudiny, Church of St. Stephen the King, $16^{\text {th }}$ century, 5.10.2009 (Obuch \& Dorica 2011).

Other species (sample-number) / ostatné druhy (vzorka-počet):

Erinaceus roumanicus (3-1), Neomys sp. (1-2), Rhinolophus euryale (1-1), Myotis mystacinus (1-3; 3-1; 4-1), Myotis brandtii (1-2), Myotis emarginatus (1-6; 5-2), Myotis nattereri (1-3; 2-1), Myotis daubentonii (1-1), Myotis dasycneme (1-1), Nyctalus leisleri (1-2), Pipistrellus nathusii (1-3), Barbastella barbastellus (1-1), Chiroptera (1-1), Lepus europaeus (1-1), Glis glis (1-1; 3-2; 4-1), Eliomys quercinus (4-2), Apodemus sp. (1-1556; 2-391), Rattus rattus (5-2), Microtus oeconomus (1-4; 4-1), Mustela erminea (1-2; 3-1), Mustela nivalis (1-6), Felis silvestris (3-1), Sus scrofa (3-1), Anas platyrhynchos (3-1), Falco tinnunculus (1-1; 3-2), Perdix perdix (1-1; 3-1), Phasianus colchicus (1-2), Gallus gallus dom. (3-1), Crex crex (4-1), Actitis hypoleucos (5-1), Streptopelia decaocto (1-13), Streptopelia turtur (1-1; 4-1), Tyto alba (1-9; 5-4), Athene noctua (1-3), Melopsittacus undulatus (1-1), Upupa epops (1-2; 3-1), Picus canus (1-1; 3-1), Lullula arborea (1-3; 5-3), Galerida cristata (1-2; 4-1; 5-3), Alaudidae (1-1; 5-1), Riparia riparia (1-5), Anthus trivialis (1-4), Anthus sp. (4-1), Motacilla alba (1-13), Lanius minor (1-2), Lanius collurio (1-2), Locustella sp. (1-1), Acrocephalus palustris (1-8), Hippolais icterina (1-2), Sylvia curruca (1-1), Sylvia nisoria (1-1), Sylvia atricapilla (1-4), Phylloscopus collybita (1-2), Regulus sp. (1-2), Sylviidae (1-1; 4-1), Muscicapa striata (1-2), Saxicola torquata (1-1), Saxicola rubetra (1-5), Luscinia megarhynchos (1-4), Turdus merula (1-6; 3-2), Turdus pilaris (1-1), Turdus philomelos (1-4), Turdus viscivorus (3-1), Turdus sp. (1-3; 4-1), Cyanistes caeruleus (1-5), Poecile palustris (1-1), Poecile montanus (1-6), Sitta europaea (1-7; 3-1), Troglodytes troglodytes (1-6; 3-1), Emberiza citrinella (1-10; 3-4), Carduelis carduelis (1-8; 3-1), Linaria cannabina (1-3), Chloris chloris (1-14; 3-3), Coccothraustes coccothraustes (1-3; 3-1), Sturnus vulgaris (1-14), Garrulus glandarius (1-1; 4-1), Corvus cornix a C. frugilegus (1-1), Coloeus monedula (1-1), Passeriformes (1-134; 2-6; 5-1), Aves sp. juv. (1-4), Bufo sp. (4-1), Rana arvalis (1-8), Pelophylax ridibundus (1-1; 5-1), Rana sp. (1-13), Amphibia (1-22; 2-10), Lacerta viridis (3-3), Lacerta agilis (1-1; 3-2; 5-1), Lacerta sp. (4-2), cf. Ablepharus kitaibeli (3-1), Natrix natrix (3-1), Coronella austriaca (3-1), Reptilia (4-1), Diptera (1-1), Melolontha melolontha (1-9), Orthoptera (1-2) 
Sicista subtilis from the pellets of T. alba in the catchment area of the River Hornád in Hungary near the Slovak border. Tatarinov (1960) studied the diet of this owl in Sub-Carpathian Rus.

Most of the mentioned collections are older than 50 years. The problem of comparing them with our subrecent data is in the level of processing of collections and determination of the species of prey of $T$. alba. In the results of Uttendörfer the majority of mammals is determined only on the level of the genus, or a higher taxonomical unit (e.g. Muridae). Similarly, in the data from Czech areas the majority of field mice is determined to the genus Apodemus sp., or Apodemus sylvaticus/flavicollis. Poprach (2008) states that the species Apodemus microps has thus far not been recorded in the Czech Republic in the diet of T. alba, although Vohralík (2002) described the sub-species Apodemus microps cimrmani from measures on maxilla obtained from the pellets of $T$. alba at Žetecká kotlina Basin, and Obuch (1992b) presents it as abundant in the diet of this owl from the Pálava area in southern Moravia. Likewise, the share of birds is strongly underestimated in the majority of works. For example, from 29 works presented from the Czech Republic by Poprach, in 4 of them birds were not determined at all and in another 9 works only on the level of class Aves. In many works the numbers of birds are determined only from the number of beaks. In Slovakia in the last 40 years we have used a $5 \%$ solution of $\mathrm{NaOH}$ for processing pellets, and we determined 4 types of bird bones according to the proposal in the handbook of Märza (1969). With determinations we use a comparative collection of bones from more than 200 bird species. By comparing the results of the determinations only from the beaks from 4 species of bones in 10 samples of food of T. alba we found out that the number of species and the number of individuals was lower by one-third (according to beaks $65 \%$ of species and $69 \%$ of individuals were determined versus $100 \%$ with determinations from 4 types of bones: humerus, metacarpus, tarsometatarsus and beaks). In the majority of European countries the method of manual dismantling of individual pellets still predominates and even the newest handbook (e.g. Yalden 2009) does not recommend the using of a $\mathrm{NaOH}$ solution for decomposing organic components. For us one collection from one location from one date, which we process at one time, is a sample. After removal of foreign matter we work with clean osteological materials from which we classify the individual elements for de- termination. We thus exclude the impreciseness of examining maxilla in fur, from the lack of integrity of pellets and the incompleteness of remnants of determined individuals. We determine the number of individuals of more difficult to determine taxons only after their thorough classification, as can be seen with certain species of the family Muridae in Fig. 2 from the subrecent sample from the Church of St. Stephen the King in Žilina.

\section{C o n c l u s i o n}

Among the owls, the most data has been published on the diet of the cosmopolitan species T. alba. This is related to the easy availability of its pellets in buildings. The results of analyses reflect proportions in the representation of prey in the parts of the landscape intensively managed by human beings. More comprehensive work from Slovakia about its diet is thus far absent. Therefore, only fragmentary parts from Slovakia are presented when evaluating the share of some taxons in its food within Europe. For example, Roulin \& Christe (2013) in their evaluation of the share of bats from the material of more than 4 million prey from Europe list 192 bats from Slovakia in 23,431 items of diet, thus a $0.82 \%$ share. In our set we present from the recent period 877 items from 19 species of bats, thus a $0.74 \%$ share of the analysed prey. Roulin (2015), working from the same Slovak materials of 23,431 pieces, evaluated the share of birds in the diet of T. alba at 1013 items $(4.32 \%)$ and the species $P$. domesticus with a share of $85.5 \%$. In our work we present from the recent period (Table 1) 58 species of birds, 4,699 pieces (3.94\%) with P. domesticus having a share of $73.9 \%$ of the material 5times larger than the mentioned authors.

\section{References}

Anděra M, Hanák V \& Krátká D 1982: Př́zpěvek k poznání fauny drobných savců Vihorlatu. Časopis Národního muzea v Praze [A contribution to knowledge of the fauna of small mammals of the Vihorlat Mts], Rada př́rodovědná 151, 4: 185-198. [In Czech with English summary]

Balát F 1956: Potrava sovy pálené (Tyto alba) na jižní Moravě a na jižním Slovensku [Diet of the barn owl (Tyto alba) in southern Moravia and southern Slovakia]. Zoologické listy 5 (3): 237-258. [In Czech with Russian and German summaries]

Botková A 2011: Drobné cicavce vo východnej časti Žitného ostrova $\mathrm{v}$ potrave sov [Small mammals in 
the eastern part of Žitný ostrov Island in the diet of owls]. Diplomová práca, Univerzita Komenského v Bratislave, prírodovedná fakulta, Katedra ekológie, 96. [In Slovak with English abstract]

Danko Š \& Štollman A 1978: Výskyt drobných hmyzožravcov a hlodavcov v juhovýchodnej časti Košickej kotliny zistený na základe rozboru sovích vývržkov [Occurrence of small insectivores and rodents in the south-eastern part of the Košická kotlina Basin determined on the basis of analysis of owl pellets]. Zborník Východoslovenského múzea v Košiciach, séria B - Prírodné vedy 18: 57-62. [In Slovak with Russian and German summaries]

Darolová A 1976: Výskum potravy plamienky driemavej - Tyto alba (Scop., 1769) na južnom Slovensku na základe rozboru vývržkov [Research on the diet of the barn owl - Tyto alba (Scop., 1769) in southern Slovakia on the basis of analysis of pellets]. Biologická olympiáda, Gymnázium Banská Bystrica, 46. [In Slovak]

Demeter G \& Obuch J 2004: Recentný výskyt myšovky stepnej (Sicista subtilis) pri Leviciach: 9 [Recent occurrence of the southern birch mouse (Sicista subtilis) near Levice]: 9. In: Kautman J \& Stloukal E (eds): Zborník abstraktov z konferencie 10. Feriancove dni. Bratislava, 25.-26.11.2004. Faunima, Bratislava, 32. [In Slovak]

Erfurt J \& Stubbe M 1986: Die Areale ausgewählter Kleinsäugerarten in der DDR. Hercyniana N. F., Leipzig 23(3): 257-304.

Flajs T \& Obuch J 2015: Reintrodukcia plamienky driemavej (Tyto alba) na sverozápadnom Slovensku: prípadová štúdia [Reintroduction of the barn owl (Tyto alba) in north-western Slovakia: a case study]. Tichodroma 27: 94-99. [In Slovak with English abstract]

Krištofík J \& Danko Š 2012: Cicavce Slovenska, rozšírenie, bionómia a ochrana [Mammals of Slovakia, distribution, bionomy and protection]. Veda, Vydavatel'stvo SAV, 711. [In Slovak with English summary]

Latková H 2007: Plamienka driemavá v podmienkach horného Záhoria [The barn owl in the upper Záhorie region]. Diplomová práca, Univerzita Komenského v Bratislave, Prírodovedná fakulta, Katedra ochrany a využívania prírody a krajiny, 108. [In Slovak with English abstract]

Libois RM 1984: Le regime alimentaire de la Chouette effraie. Cahiers d' Ethologie Appliquee 4 (2): 202.
Mazúr E \& Lukniš M 1980: Geomorfologické jednotky. Mapa 1:500 000 [Geomorphological units. Cart 1:500,000], 54-55. In: Atlas Slovenskej socoalistickej republiky, SAV Bratislava, Slovenský úrad geodézie a kartografie, 296. [In Slovak with Russian and English explanations]

Noga M 2005: Význam sledovania osteologických nálezov z potravy dravcov a sov [The importance of monitoring osteological findings from the food of raptors and owls]. Bakalárska práca, Univerzita Konštantína Filozofa v Nitre, Fakulta prírodných vied, Katedra ekológie a enviromentalistiky, 67. [In Slovak with English abstract]

Noga M \& Obuch J 2004: Hraboš severský Microtus oeconomus $\mathrm{v}$ potrave sov na Slovensku [The root vole Microtus oeconomus in the food of owls in Slovakia], 195-196. In: Bryja J \& Zukal J (eds), Zoologické dny Brno 2004, Sborník abstraktů z konference, Ústav biologie obratlovců AV ČR, Brno, 232. [In Slovak]

Obuch J 1980: Potrava sovy obyčajnej (Strix aluco) a iné osteologické nálezy z Hornej Nitry [The food of the tawny owl (Strix aluco) and other osteological findings from the Upper Nitra], 104-105. In: Galvánek J \& Šimurková A (eds), 15. tábor ochrancov prírody, Prehl'ad odborných výsledkov, Prievidza, 134. [In Slovak]

Obuch J 1982: Náčrt potravnej ekológie sov (Striges) v strednej časti Turca [An outline of the food ecology of owls (Striges) in the central part of the Turiec]. Kmetianum 6: 81-106. [In Slovak with Russian and German summary]

Obuch J 1992a: Potrava sov v okolí Moldavy nad Bodvou [The owl's diet in surroundings of Moldava nad Bodvou town], 190-197. In: Fulín M (ed.): XV. Východoslovenský tábor ochrancov prírody. Prehl'ad odborných výsledkov. Štós-Porča, 28.7. - 2.8.1991. Okresný koordinačný výbor Slovenského zväzu ochrancov prírody a krajiny Košice-vidiek a OÚŽP Košice-vidiek. Moldava nad Bodvou, 222. [In Slovak]

Obuch J 1992b: Porovnanie potravy 4 druhov sov z 3 území ČSFR [Diet comparison of four owl species from three regions of the Czechoslovak Federal Republic]. Zprávy MOS, Přerov, 50: 17-25. [in Slovak with English summary]

Obuch J 1995: Materiály $\mathrm{k}$ potrave sov $\mathrm{v}$ okolí Rimavskej Soboty [Data on the owl's diet in the surroundings of the Rimavská Sobota town], 
109-113. In: Krištín A \& Gaálová K (eds): Rimava 1995, Odborné výsledky zoologických a mykologických výskumov, SAŽP \& ÚEL, Banská Bystrica \& Zvolen, 118. [In Slovak with English summary]

Obuch J 1998: Monitoring cicavcov v Slovenskom krase pomocou analýzy potravy sov [Monitoring of mammals in the Slovenský kras Mts using owl diet analyses], 91-101. In: Urban P (ed.): Výskum a ochrana cicavcov na Slovensku 3. SAŽP-COPaK Banská Bystrica, Ústav ekológie lesa SAV Zvolen, Stredoslovenská pobočka SZS SAV Zvolen. Banská Bystrica, 156. [In Slovak]

Obuch J 2000: Potrava sov v Drienčanskom krase a v okolitých územiach [The diet of owls in the Drienčanský kras Mts and surrounding areas (southcentral Slovakia)], 255-266. In: Kliment J (ed): Príroda Drienčanského krasu, Banská Bystrica, 280. [In Slovak with English abstract]

Obuch J 2002: Cicavce (Mammalia) v potrave sov (Strigiformes) vo Vel'kej Fatre [The Mammals (Mammalia) in diet of owls (Strigiformes) in the Vel'ká Fatra Mts]. Matthias Belius Univ. Proc. 2, Suppl. 1: 219-229. [In Slovak with English abstract]

Obuch J 2014: Ako sme s Gabom našli myšovku stepnú [How we discovered southern birch mouse with Gabo]. Dravce a sovy 10 (2): 23-25. [In Slovak with English summary]

Obuch J \& Darola J 1980: Poznatky o zložení a vývoji teriofauny Gaderskej doliny na základe osteologických nálezov [Notions on the composition and evolution of terriofauna of the Gaderská dolina Valley on the basis of osteologic deposits]. Výskum prírody, ochrana prírody, Bratislava 3C: 325-354. [In Slovak with Russian, German and English summary]

Obuch J \& Dorica J 2011: Potrava plamienky driemavej (Tyto alba) zo 16. storočia v Kostole sv. Štefana král'a v Žiline-Dolných Rudinách [Diet of the barn owl (Tyto alba) from the $16^{\text {th }}$ century in the Church of St. Stephen the King in Žilina -Dolné Rudiny], 164 . In: Bryja J, ̌̌ehák Z \& Zukal J (eds): Zoologické dny Brno 2011, Sborník abstraktů z konference, Ústav biologie obratlovců AV ČR, Brno, 282. [In Slovak]

Obuch J \& Kadlečík J 1997: Letný výskyt netopierov v budovách Turca [Summer occurrence of bats in buildings in the Turiec area (NW Slovakia)]. Vespertilio 2: 51-58. [In Slovak with English abstract]

Obuch J \& Kürthy A 1995: Potrava troch druhov sov spoločne sídliacich v budovách [Food of three spe- cies of owls commonly settled in buildings]. Buteo 7: 27-36. [In Slovak]

Obuch J \& Uhrin M 1997: Príspevok k faune drobných cicavcov Novohradu (Insectivora, Chiroptera, Rodentia) [A contribution on the small mammal fauna of Novohrad (Insectivora, Chiroptera, Rodentia)], 95-103. In: Urban P \& Hrivnák R (eds): Poiplie, Zborník odborných výsledkov zo stretnutia prírodovedcov Novohrad 1996 a Poiplie 1997, SAŽP, Banská Bystrica, 149. [In Slovak]

Obuch J \& Matis Š 1998: Náčrt potravy plamienky driemavej (Tyto alba) v Košickej kotline [An outline of the diet of the barn owl (Tyto alba) in the Košická kotlina Basin]. Natura carpatica 39: 263-272. [In Slovak with English summary]

Petrželková KJ, Obuch J \& Zukal J 2004: Does the barn owl (Tyto alba) selectively predate individual great mouse-eared bats (Myotis myotis)? Lynx (Praha), n. s. $35: 123-132$.

Poprach K 2008: Sova pálená [The barn owl]. Tyto, Nenakonice, 400. [In Czech with English summary]

Pucek Z \& Raczyński J 1983: Atlas rozmieszczenia ssaków w Polsce [Atlas of mammals distributin in Poland]. PAN, Warszawa, 188. [In Polish with English summary]

Roulin A 2015: Spatial variation in the decline of European birds as shown by the barn owl Tyto alba diet. Bird Study 62: 271-275.

Roulin A \& Christe P 2013: Geographic and temporal variation in the consumption of bats by European barn owls. Bird Study 60: 561-569.

Sanitár M 2001: Analýza potravy a význam sov (Strigiformes) v dvoch oblastiach Slovenska (Zvolenská kotlina a Ipel'ská pahorkatina) [Analysis of the diet and importance of owls (Strigiformes) in two areas of Slovakia (Zvolenská kotlina Basin and the Ipel'ská pahorkatina Hills)]. Diplomová práca, FEE TU Zvolen, 40. [In Slovak with English abstract]

Sárossy M 1999a: Rozšírenie a ochrana plamienky driemavej (Tyto alba) na Slovensku [Distribution and protection of the barn owl (Tyto alba) in Slovakia]. Diplomová práca, FEE TU Zvolen, 77. [In Slovak]

Sárossy M 1999b: Plamienka driemavá na Slovensku. Stav poznatkov o rozšírení, početnosti a ochrane do roku 2000 [The barn owl in Slovakia. State of knowledge on distribution, abundance and protection to year 2000]. Plamienka, Zvolen, 18. [In Slovak] 
Sárossy M 1999c: Plamienka driemavá (Tyto alba). Prehl'ad údajov o výskyte plamienky na Slovensku zaznamenaných do roku 2000 [The barn owl (Tyto $a l b a)$. An overview of data on the occurrence of the barn owl in Slovakia recorded to the year 2000]. Plamienka, Zvolen, 35. [In Slovak]

Schaefer 1933: Eine interessante Beutetierliste der Schleiereule am Fusse der Hohen Tatra. Zoologische Anzeiger 101 (5/6): 164-167.

Schmidt E 1973: Die Nahrung der Schleiereule (Tyto alba) in Europe. Angewandte Zoolgie 60: 43-70.

Schmidt E \& Sipos G 1971: Kleinsäugerfaunistische Angaben aus Hernadbecken auf Grund der Gewölluntesuchungen der Schleiereulen (Tyto alba Scop.). Tiscia (Szeged) 6: 101-108.

Schmidt E \& Štollmann A 1972: Potrava plamienky driemavej (Tyto alba guttata Brehm, 1831) v Turčianskej kotline [Diet of the barn owl (Tyto alba guttata Brehm, 1831) in the Turčianská kotlina Basin]. Prírodovedný zborník Slovenského národného múzea 18: 139-142. [In Slovak with German summary]

Shannon CE \& Weaver W 1949: The mathematical theory of communication. The University of Illinois Press, Urbana, 125.

Šipöcz T 2004: Zber. Databázový program, Verzia 3. [Collection. Database program. Version 3]. Botanical Garden, Comenius University, Blatnica. [In Slovak]

Tatarinov KA 1960: Pitanie sipuchi, Tyto alba (Scop.), $\mathrm{v}$ severnich rajonach Panonskoj nizmennosti [Diet of the barn owl in the north part of Panonia lowland]. Trudy problemnych i tematičeskich soveščanij ZIN 9: 230-232. [In Russian]

Tirinda A 1993: Drobné zemné cicavce v potrave niektorých druhov sov v okolí Galanty [Micromammals as components of food of some owls in the Galanta district]. Tichodroma 5: 95-101. [In Slovak with English summary]

Uhrin M, Benda P, Obuch J \& Urban P 2002: K poznaniu fauny cicavcov Drienčanského krasu a okolia (stredné Slovensko) [Mammals fauna of the Drienčanský kras Karst Region and surrounding areas (central Slovakia)]. Lynx (Praha), n. s. 33: 193-247. [In Slovak with English abstract]

Uttendörfer O 1952: Neue Ergebnisse über die Ernährung der Greifvögel und Eulen. Ver. Eugen Ulmer, Stuttgart, 189.

Veselovský T 2014: Čo sa stalo s plamienkou? [What has happened to the barn owl?] Dravce a sovy 10 (2): 21-22. [In Slovak with English summary]

Vohralík V 2002: Distribution, skull morphometrics and systematic status of an isolated population of Apodemus microps (Mammalia: Rodentia) in NW Bohemia, Czech Republic. Acta Societatis Zoologicae Bohemicae 66: 67-80.

Vondráček J \& Hošek V 1984: Příspěvek k potravní ekologii sovy pálené [Tyto alba guttata (Brehm)] z oblasti jižního Slovenska [Contribution to foraing ecology of the barn owl [Tyto alba guttata (Brehm)] in southern Slovakia]. Ochrana prírody 5: 135-147. [In Czech with Russian, German and English summary]

Vongrej S 2015: Aké sú príčiny silného poklesu populácie plamienky driemavej na Hornom Záhorí? [What are the reasons for the strong decline in the population of barn owls in the Upper Záhorie?] Vtáky 10 (4): 6-7. [In Slovak]

Yalden DW 2009: The analysis of owl pellets, $4^{\text {th }}$ edition. The Mammal Society, London, 28. 


\section{Appendix 1.}

Samples of Tyto alba diet from Chvojnická pahorkatina Hills. Numerical values in the table are presented in absolute value; positive and negative deviations (1+, 2+, and 1-, 2-) are a marked differences from the mean (Obuch 2001) within a respective species, across locations. For more details see Methods. The diversity index 'H' is used, calculated according to the work of Shannon \& Weaver (1949).

Vzorky potravy Tyto alba z Chvojnickej pahorkatiny. Číselné hodnoty v tabul'ke sú uvedené v absolútnych hodnodnotách, kladné a záporné odchýlky (1+, 2+ a 1-, 2-) sú významné odchýlky od priemeru (Obuch 2001) v rámci toho istého druhu, naprieč lokalitami. Pre viac informácii pozri Metodiku. Použitý je index diverzity H', vypočítaný podla práce Shannon \& Weaver (1949).

\begin{tabular}{|c|c|c|c|c|c|c|c|c|c|c|c|c|c|c|c|c|c|}
\hline \multirow{2}{*}{$\begin{array}{l}\text { localities / lokality } \\
\text { taxa / taxón } \\
\text { Sorex araneus }\end{array}$} & & \multicolumn{2}{|r|}{2} & \multicolumn{2}{|r|}{5} & \multicolumn{2}{|r|}{3} & \multicolumn{2}{|r|}{4} & \multicolumn{2}{|r|}{6} & \multicolumn{2}{|r|}{19} & \multicolumn{2}{|c|}{18} & \multicolumn{2}{|c|}{1} \\
\hline & & $1+$ & 39 & $2+$ & 189 & $1+$ & 73 & $1+$ & 31 & $1+$ & 30 & $1+$ & 19 & & 63 & & 29 \\
\hline Neomys fodiens & & & 1 & $1+$ & 8 & & 1 & & & & & & 1 & & & & 2 \\
\hline Sorex minutus & & & 9 & $2+$ & 84 & $1+$ & 19 & & 6 & & 7 & & 2 & $1-$ & 21 & & 6 \\
\hline Crocidura leucodon & & & 13 & $1+$ & 44 & $1+$ & 41 & $1+$ & 15 & & 6 & & 9 & $1-$ & 20 & & 16 \\
\hline Passer domesticus & & & 7 & $1-$ & 9 & & 11 & $1-$ & 2 & $1+$ & 20 & & 6 & & 37 & & 14 \\
\hline Mus cf. musculus & & $2-$ & 0 & $2-$ & 3 & & 12 & & 7 & & 4 & $1+$ & 16 & $1+$ & 80 & $1+$ & 19 \\
\hline Rattus norvegicus & & & & $1-$ & 0 & & 2 & & 1 & & & & & & 4 & & 3 \\
\hline Phoenicurus ochruros & & & & & 1 & & 1 & & 2 & & & & 1 & & 2 & & 1 \\
\hline Crocidura suaveolens & & & 6 & $1+$ & 28 & & 5 & & 4 & & 6 & & 7 & & 14 & & 7 \\
\hline Neomys anomalus & & & 1 & & 5 & & 1 & & & & & & & & & & \\
\hline Hirundo rustica & & & & & 2 & & & & & & & & & & & & \\
\hline Micromys minutus & & & 5 & $1+$ & 22 & & 3 & & 1 & & & & 6 & & 17 & & 3 \\
\hline Apodemus flavicollis & & & & $2-$ & 0 & & 3 & & 5 & & 1 & & & $1-$ & 2 & & 3 \\
\hline Apodemus sylvaticus & & & 4 & $2-$ & 3 & & 10 & & 7 & $1-$ & 0 & & 4 & & 20 & & 6 \\
\hline Apodemus microps & & & 3 & & 19 & & 9 & $1+$ & 19 & $1-$ & 0 & & 7 & $1+$ & 36 & & 13 \\
\hline Microtus arvalis & $\mathrm{n}$ & & 156 & $1-$ & 273 & $1-$ & 191 & $1-$ & 118 & & 146 & $1-$ & 75 & & 622 & & 210 \\
\hline Clethrionomyc alare & - $\%$ & & 63.93 & & 39.22 & & 48.97 & & 53.15 & & 65.77 & & 47.47 & & 65.54 & & 3.25 \\
\hline $\begin{array}{l}\text { Clethrionomys glareolu } \\
\text { Arvicola amphibius }\end{array}$ & & & & & $\begin{array}{l}2 \\
3\end{array}$ & & 5 & & 2 & & 2 & & 1 & & P & & \\
\hline Delichon urbica & & & & & & & & & & & & & 1 & & & & \\
\hline Mammalia & & & 237 & & 684 & & 375 & & 216 & & 202 & & 147 & & 906 & & 317 \\
\hline Aves & & & 7 & 1- & 12 & & 15 & & 6 & $1+$ & 20 & & 11 & & 43 & & 15 \\
\hline $\bar{\Sigma}$ & & & 244 & & 696 & & 390 & & 222 & & 222 & & 158 & & 949 & & 332 \\
\hline $\mathrm{H}^{\prime}$ & & & 1.30 & & 1.75 & & 1.74 & & 1.70 & & 1.21 & & 1.89 & & 1.42 & & 1.48 \\
\hline
\end{tabular}

\begin{tabular}{|c|c|c|c|c|c|c|c|c|c|c|c|c|c|c|c|}
\hline $\begin{array}{l}\text { localities / lokality } \\
\text { taxa / taxón }\end{array}$ & & & 14 & & 13 & & 21 & & 20 & & 15 & & 17 & 24 & 26 \\
\hline Sorex araneus & & $2-$ & 14 & $1-$ & 9 & $2-$ & 15 & $1-$ & 10 & $1-$ & 29 & $2-$ & 2.2 & $1-$ & \\
\hline Neomys fodiens & & & & & & & & & & & & & & & \\
\hline Sorex minutus & & $1-$ & 7 & $1-$ & 5 & $2-$ & 5 & & 4 & $1-$ & 7 & & 2 & & \\
\hline Crocidura leucodon & & $1-$ & 12 & & 13 & & 27 & & 10 & & 21 & $1-$ & 1 & & \\
\hline Passer domesticus & & $3-$ & 1 & $1-$ & 3 & & 28 & & 9 & $1-$ & 8 & & 6 & & \\
\hline Mus cf. musculus & & & 27 & & 8 & & 21 & & 12 & $1-$ & 6 & & 6 & 1 & 3 \\
\hline Rattus norvegicus & & $1-$ & 1 & & & $1-$ & 1 & & 1 & & 4 & & & & \\
\hline Phoenicurus ochruros & & $1+$ & 8 & & 1 & & 3 & & & & & & & & \\
\hline Crocidura suaveolens & & $1+$ & 23 & $1+$ & 14 & & 16 & & 3 & 1- & 6 & & 2 & & 1 \\
\hline Neomys anomalus & & & & $2+$ & 14 & $1+$ & 7 & & & & & & & & \\
\hline Hirundo rustica & & & 2 & & & $1+$ & 6 & & & & & & & & \\
\hline Micromys minutus & & $1-$ & 1 & $1+$ & 12 & & 5 & $1+$ & 12 & & 5 & & 4 & 1 & \\
\hline Apodemus flavicollis & & $1+$ & 20 & $1+$ & 13 & & 7 & & 6 & $1+$ & 21 & & 1 & 1 & \\
\hline Apodemus sylvaticus & & $1+$ & 32 & & 6 & $1-$ & 9 & $1-$ & 0 & $1+$ & 23 & & 5 & & \\
\hline Apodemus microps & & & 23 & $1+$ & 18 & $2-$ & 4 & & 3 & $1+$ & 30 & $2+$ & 20 & & \\
\hline Microtus arvalis & $\mathrm{n}$ & & 542 & & 254 & & 537 & & 160 & & 376 & & 134 & 68 & $1+38$ \\
\hline & $\%$ & & 75.07 & & 68.10 & & 76.60 & & 69.26 & & 69.63 & & 72.83 & 93.15 & 90.48 \\
\hline Clethrionomys glareolus & & & 1 & & 1 & & 4 & & & & 1 & & & 1 & \\
\hline Arvicola amphibius & & & 1 & & & & & & & & & & & & \\
\hline Delichon urbica & & & 3 & & & & 2 & & & & & & & & \\
\hline Mammalia & & & 706 & & 369 & & 659 & & 222 & & 532 & & 178 & 72 & 42 \\
\hline Aves & & 1- & 16 & $1-$ & 4 & $1+$ & 42 & & 9 & $1-$ & 8 & & 6 & 1 & 0 \\
\hline$\Sigma$ & & & 722 & & 373 & & 701 & & 231 & & 540 & & 184 & 73 & 42 \\
\hline$H^{\prime}$ & & & 1.15 & & 1.40 & & 1.14 & & 1.28 & & 1.30 & & 1.11 & 0.36 & 0.37 \\
\hline
\end{tabular}

Locality / lokalita: 2 - Borský Peter, 5 - Brodské, 3 - Štefanov, 4 - Smolinské, 6 - Smrdáky, 19 - Hlboké, 18 - Vrádište, 1993 + Latková (2007), 1 - Skalica, 7 - Cunín, 23 - Gbely, 8 - Čáry, 9 - Oreské, 10 - Letničie, 11 - Senica, 12 - Petrova Ves, 16 - Prietržka, 22 - Radimov, 14 - Dubovce, 13 - Chropov, 21 - Čáčov, 20 - Radošovce, 15 - Unín, 17 - Trnovec, 24 - Popudinské Močidlany, 26 - Rovensko, 27 - Mokrý Háj, 28 - Koválov, 29 - Holíč, 30 - Dojč, 25 - Kunov, 31 - Rybky, 32 - Kopčany, 33 - Horné Suroviny, 34 - Prietrž. Published in Latková (2007). 
Slovak Raptor Journal 2016, 10: 1-50. DOI: 10.1515/srj-2016-0003.

(C) Raptor Protection of Slovakia (RPS)

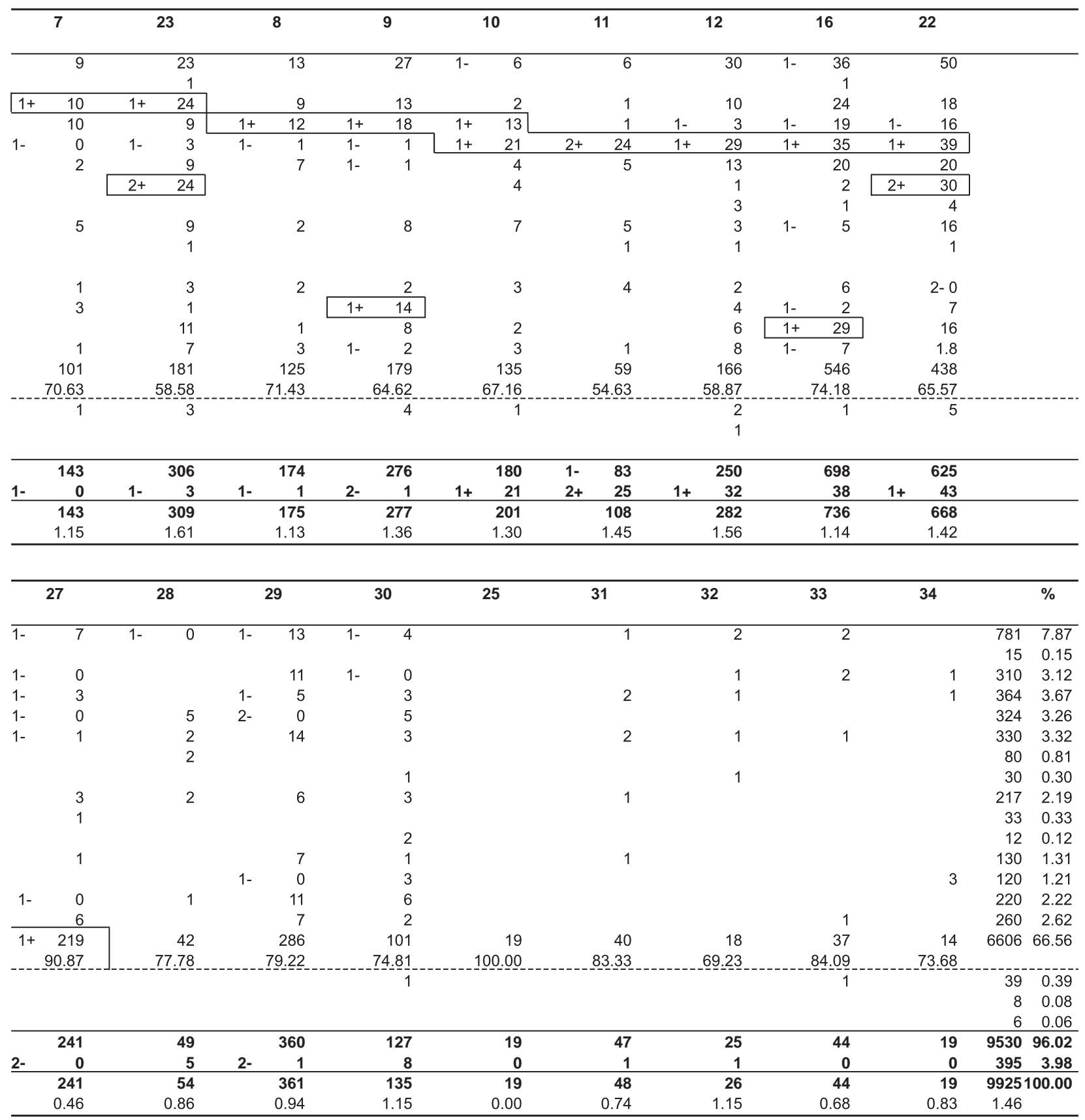

Other species (locality-number) / ostatné druhy (lokalita-počet): Talpa europaea (5-1; 18-1; 14-2), Nyctalus leisleri (18-1), Pipistrellus nathusii (21-1), Plecotus austriacus (13-1), Muscardinus avellanarius (20-1), Apodemus sp. (13-1; 15-2; 32-2), Terricola subterraneus (18-2), Mustela erminea (15-1; 17-1), Erithacus rubecula (4-1; 19-2; 18-1), Parus major (18-1; 21-1), Troglodytes troglodytes (3-2), Fringilla coelebs (3-1; 4-1), Carduelis carduelis (21-1), Passer montanus (11-1; 14-2; 16-2), Sturnus vulgaris (19-1), Passeriformes $(18-2 ; 21-1 ; 24-1 ; 29-1 ; 31-1)$. 


\section{Appendix 2.}

Samples of $T$. alba diet from Borská nižina Lowland. Numerical values in the table are presented in absolute value; positive and negative deviations $(1+, 2+$, and 1-, 2-) are a marked differences from the mean (Obuch 2001) within a respective species, across locations. For more details see Methods. The diversity index $\mathrm{H}^{\prime}$ is used, calculated according to the work of Shannon \& Weaver (1949).

Vzorky potravy $T$. alba z Borskej nížiny. Číselné hodnoty $v$ tabul'ke sú uvedené $v$ absolútnych hodnodnotách, kladné a záporné odchýlky (1+, 2+ a 1-, 2-) sú významné odchýlky od priemeru (Obuch 2001) v rámci toho istého druhu, naprieč lokalitami. Pre viac informácii pozri Metodiku. Použitý je index diverzity H', vypočítaný podla práce Shannon \& Weaver (1949).

\begin{tabular}{|c|c|c|c|c|c|c|c|c|c|c|c|c|c|c|c|}
\hline \multirow{2}{*}{$\begin{array}{l}\text { localities / lokality } \\
\text { taxa / taxón } \\
\text { Neomys fodiens }\end{array}$} & \multicolumn{3}{|r|}{1} & \multicolumn{2}{|r|}{3} & \multicolumn{2}{|r|}{7} & \multicolumn{2}{|r|}{12} & \multicolumn{2}{|c|}{13} & \multicolumn{2}{|r|}{11} & \multicolumn{2}{|c|}{10} \\
\hline & & $1+$ & 18 & & 1 & & 1 & & 11 & & & & & & \\
\hline Neomys anomalus & & & 5 & $1+$ & 5 & & & & & & & & & & \\
\hline Parus major & & & 11 & $2+$ & 11 & & & $1-$ & 0 & & & & & & 1 \\
\hline Sorex araneus & & $1-$ & 291 & $1+$ & 59 & $1+$ & 25 & $1+$ & 555 & $1+$ & 38 & & 73 & $1-$ & 22 \\
\hline Sorex minutus & & $1-$ & 69 & & 14 & $1+$ & 13 & $1+$ & 189 & & 13 & $1+$ & 41 & $1-$ & 4 \\
\hline Coleoptera & & $2-$ & 0 & & & & & $2+$ & 50 & & & & & & \\
\hline Clethrionomys glareolus & & $1-$ & 19 & & 3 & & 4 & $1+$ & 80 & & 3 & & 3 & & 2 \\
\hline Apodemus flavicollis & & $1-$ & 8 & & 2 & & 1 & $1+$ & 41 & & 1 & & 7 & & 1 \\
\hline Apodemus microps & & $1-$ & 11 & & 6 & & & $1+$ & 38 & & & & 3 & & 2 \\
\hline Hirundo rustica & & & 5 & & 1 & & & $1-$ & 0 & & 3 & & 2 & $1+$ & 9 \\
\hline Micromys minutus & & $1-$ & 35 & & 7 & & & & 45 & $1+$ & 12 & $1+$ & 20 & $1+$ & 12 \\
\hline Mus cf. musculus & & & 211 & & 22 & & 1 & $1-$ & 135 & $1+$ & 20 & & 36 & $1+$ & 62 \\
\hline Crocidura suaveolens & & $1-$ & 76 & & 8 & & 2 & & 102 & & 9 & & 22 & $1+$ & 30 \\
\hline Crocidura leucodon & & $1-$ & 97 & & 10 & & & $1-$ & 106 & $1+$ & 22 & $1+$ & 47 & $1+$ & 46 \\
\hline Rattus norvegicus & & & 7 & & & & 1 & & 3 & & & & 1 & & \\
\hline Passer montanus & & & 3 & & 2 & & & & 3 & & & & 1 & & 1 \\
\hline Passer domesticus & & & 132 & $2+$ & 46 & & 1 & & 132 & & 4 & $1-$ & 15 & $1+$ & 33 \\
\hline Apodemus sylvaticus & & $1-$ & 101 & & 7 & & & & 99 & & 6 & & 29 & $1+$ & 27 \\
\hline Microtus arvalis & $\mathrm{n}$ & & 2784 & $1-$ & 90 & $1-$ & 31 & $1-$ & 1669 & $1-$ & 100 & & 333 & $1-$ & 238 \\
\hline & $\%$ & & 70.66 & & 29.80 & & 38.27 & & 50.92 & & 42.37 & & 52.19 & & 47.60 \\
\hline Terricola subterraneus & & $1-$ & 1 & & & & 1 & & 8 & & 1 & & 1 & & 1 \\
\hline Phoenicurus ochruros & & & 8 & & 1 & & & $1-$ & 0 & & & & 1 & & 1 \\
\hline Fringilla coelebs & & & 8 & & & & & & & & & & & & 3 \\
\hline Delichon urbica & & & 6 & & 3 & & & & & & & & & & 1 \\
\hline Arvicola amphibius & & & 3 & & & & & & 1 & & & & & & 2 \\
\hline Alauda arvensis & & & 3 & & & & & & 2 & & & & & & 1 \\
\hline Erithacus rubecula & & & 5 & & & & & & & & 1 & & & & \\
\hline Motacilla alba & & & 5 & & & & & & & & & & & & \\
\hline Pelophylax cf. esculentus & & & 1 & & & & & & 1 & & 1 & & 1 & & \\
\hline Mammalia & & & 3741 & & 237 & & 80 & & 3083 & & 225 & & 617 & & 449 \\
\hline Aves & & & 198 & $2+$ & 65 & & 1 & & 143 & & 10 & $1-$ & 20 & $1+$ & 51 \\
\hline Amphibia & & & 1 & & 0 & & 0 & & 2 & & 1 & & 1 & & 0 \\
\hline Invertebrata & & 2- & 0 & & 0 & & 0 & $2+$ & 50 & & 0 & & 0 & & 0 \\
\hline$\sum$ & & & 3940 & & 302 & & 81 & & 3278 & & 236 & & 638 & & 500 \\
\hline $\mathrm{H}^{\prime}$ & & & 1.31 & & 2.24 & & 1.59 & & 1.79 & & 1.94 & & 1.76 & & 1.87 \\
\hline
\end{tabular}

Locality / Iokalita: 1 - Dolečky, 3 - Jablonica, Noga (2005) + Latková (2007), 7 - Malé Leváre, Obuch \& Kürthy (1995), 12 - Vysoká pri Morave, 1992, leg. Darolová + Obuch \& Kürthy (1995) + Noga (2005), 13 - Záhorská Ves, 11 - Suchohrad, 10 - Plavecký Štvrtok, 4 - Jakubov, 8 - Marcheggské mosty, 6 - Láb, 5 - Karlov dvor, 2 - Gajary, 9. 1994, leg. Kürthy, 14 - Šaštín-Stráže, 1978 , leg. Mayer + Noga (2005), 9 - Nandin dvor.

Other species (locality-number) / ostatné druhy (lokalita-počet): Talpa europaea (12-1; 5-1; 9-1), Myotis nattereri (8-1), Myotis myotis (1-1), Myotis daubentonii (1-1), Nyctalus noctula (8-1), Nyctalus leisleri (1-1), Pipistrellus pipistrellus (3-2), Pipistrellus nathusii (1-1), Plecotus auritus (11-1), Plecotus austriacus (5-1; 9-1), Muscardinus avellanarius (1-1; 3-1; 5-2), Apodemus sp. (14-6), Microtus agrestis (5-1), Falco tinnunculus (8-1), Perdix perdix (5-1), Phasianus colchicus (8-2), Apus apus (1-2; 4-1), Melopsittacus undulatus (1-1), Lullula arborea (1-1), Riparia riparia (12-2), Sylvia atricapilla (1-2; 11-1), Phylloscopus collybita (12-1), Sylviidae (13-1), Luscinia megarhynchos (1-1), Turdus pilaris (8-1), Turdus philomelos (8-1), Sitta europaea (1-1; 10-1), Emberiza citrinella (1-1; 5-1), Linaria cannabina (1-1), Chloris chloris (1-2; 12-1), Sturnus vulgaris (9-1), Garrulus glandarius (8-1), Corvus cornix a C. frugilegus (12-1), Coloeus monedula (8-1), Passeriformes (3-1; 12-1; 13-1; 4-3; 8-4), Pelobates fuscus (12-1; 8-1). 
Slovak Raptor Journal 2016, 10: 1-50. DOI: 10.1515/srj-2016-0003.

(C) Raptor Protection of Slovakia (RPS)

\begin{tabular}{|c|c|c|c|c|c|c|c|c|c|c|c|c|c|c|c|}
\hline \multicolumn{2}{|r|}{4} & \multicolumn{2}{|r|}{8} & \multicolumn{2}{|r|}{6} & \multicolumn{2}{|r|}{5} & \multicolumn{2}{|r|}{2} & \multicolumn{2}{|c|}{14} & \multicolumn{2}{|r|}{9} & $\bar{\Sigma}$ & \multirow[t]{2}{*}{$\%$} \\
\hline & & & 2 & & 1 & & & & & & 1 & & 4 & 39 & \\
\hline & & & 1 & & & & & & & & & & 1 & 12 & 0.09 \\
\hline & & & & & & & & & & & 3 & & & 26 & 0.19 \\
\hline \multirow[t]{7}{*}{$1-$} & 27 & $1-$ & 48 & & 2 & $1-$ & 53 & $1-$ & 9 & $1-$ & 24 & & 98 & 1324 & 9.47 \\
\hline & 17 & 2- & 7 & & 4 & & 36 & $1-$ & 3 & $1-$ & 9 & & 28 & 447 & 3.20 \\
\hline & & $1-$ & 0 & & & $1-$ & 0 & & & & & & & 50 & 0.36 \\
\hline & 9 & $1-$ & 4 & & 4 & & 11 & & & & 2 & & 11 & 155 & 1.11 \\
\hline & 2 & & 10 & & & $1+$ & 18 & & & & 3 & $1-$ & 1 & 95 & 0.68 \\
\hline & 2 & $1-$ & 1 & & 1 & & 8 & & & $1+$ & 10 & & 3 & 85 & 0.61 \\
\hline & & & & & & & & & & & & & & 20 & 0.14 \\
\hline $1+$ & 19 & $1-$ & 4 & & 2 & & 12 & & 1 & $1-$ & 2 & & 8 & 179 & 1.28 \\
\hline $2+$ & 140 & $3-$ & 5 & & 5 & 2- & 21 & & 18 & & 25 & $1-$ & 29 & 730 & 5.22 \\
\hline $1+$ & 34 & $1+$ & 72 & & 4 & & 33 & & 8 & $1-$ & 6 & & 29 & 435 & 3.11 \\
\hline $1+$ & 47 & $1+$ & 75 & $1+$ & 7 & $1+$ & 89 & $1+$ & 25 & & 19 & $1-$ & 20 & 610 & 4.36 \\
\hline $2+$ & 15 & & & & & & 3 & & 1 & & & & & 31 & 0.22 \\
\hline $1+$ & 6 & & 2 & & & & & & & & & & & 18 & 0.13 \\
\hline $1+$ & 58 & 3- & 5 & & 2 & $1-$ & 27 & $1-$ & 3 & $1+$ & 36 & $2-$ & 5 & 499 & 3.57 \\
\hline $1+$ & 33 & $1-$ & 27 & $1+$ & 9 & $1+$ & 89 & & 15 & $2-$ & 3 & $1-$ & 16 & 461 & 3.30 \\
\hline \multirow[t]{4}{*}{$1-$} & 226 & $1+$ & 878 & 1- & 14 & & 914 & & 197 & & 393 & & 726 & 8593 & 61.48 \\
\hline & 35.04 & & 75.62 & & 25.45 & & 68.88 & & 70.36 & & 71.72 & & 73.63 & & \\
\hline & & & 2 & & & & 3 & & & & 1 & & 2 & 21 & 0.15 \\
\hline & 3 & & & & & & 1 & & & & 4 & & & 19 & 0.14 \\
\hline & & & 1 & & & & 1 & & & & & & 1 & 14 & 0.10 \\
\hline & 2 & & & & & & & & & & & & & 12 & 0.09 \\
\hline & & & 1 & & & & 1 & & & & & & & 8 & 0.06 \\
\hline & & & 1 & & & & & & & & & & & 7 & 0.05 \\
\hline & 1 & & & & & & & & & & & & & 7 & 0.05 \\
\hline & & & & & & & & & & & 1 & & & 6 & 0.04 \\
\hline & & & 1 & & & & & & & & & & 1 & 6 & 0.04 \\
\hline & 571 & & 1139 & & 53 & & 1296 & & 277 & & 504 & & 978 & 13,250 & 94.80 \\
\hline \multirow[t]{5}{*}{$1+$} & 74 & 1- & 20 & & 2 & 1- & 31 & $1-$ & 3 & $1+$ & 44 & $2-$ & 7 & 669 & 4.79 \\
\hline & 0 & & 2 & & 0 & & 0 & & 0 & & 0 & & 1 & 8 & 0.06 \\
\hline & 0 & & 1- 0 & & 0 & & 1- 0 & & 0 & & 0 & & 0 & 50 & 0.36 \\
\hline & 645 & & 1161 & & 55 & & 1327 & & 280 & & 548 & & 986 & 13,977 & 100.00 \\
\hline & 2.6 & & 1.9 & & 2.20 & & 1.33 & & 1.15 & & 1.25 & & 1.13 & 1.61 & \\
\hline
\end{tabular}




\section{Appendix 3.}

Samples of T. alba diet from Podunajská rovina Plain. Numerical values in the table are presented in absolute value; positive and negative deviations (1+, 2+, and 1-, 2-) are a marked differences from the mean (Obuch 2001) within a respective species, across locations. For more details see Methods. The diversity index H' is used, calculated according to the work of Shannon \& Weaver (1949).

Vzorky potravy T. alba z Podunajskej roviny. Číselné hodnoty v tabul'ke sú uvedené v absolútnych hodnodnotách, kladné a záporné odchýlky (1+, 2+ a 1-, 2-) sú významné odchýlky od priemeru (Obuch 2001) v rámci toho istého druhu, naprieč lokalitami. Pre viac informácii pozri Metodiku. Použitý je index diverzity H', vypočítaný podla práce Shannon \& Weaver (1949).

\begin{tabular}{|c|c|c|c|c|c|c|c|c|c|c|c|}
\hline $\begin{array}{l}\text { localities / lokality } \\
\text { taxa / taxón }\end{array}$ & & 6 & 8 & 12 & 16 & $\overline{1}$ & & 5 & 7 & 1 & 2 \\
\hline \multirow[t]{2}{*}{ Microtus arvalis } & $\mathrm{n}$ & $1+\quad 67$ & $1+258$ & $1+$ & $1+107$ & & 214 & $1-\quad 124$ & $2-\quad 26$ & $1-609$ & $1-188$ \\
\hline & $\%$ & 88.16 & 88.36 & 89.89 & 89.92 & & 1.68 & 30.02 & 16.35 & 56.39 & 52.66 \\
\hline Rattus norvegicus & & & & 1 & 3 & $1+$ & 7 & $1+$ & & 9 & 3 \\
\hline Passer domesticus & & 1 & $1-$ & & 1 & & 7 & $2+$ & $1-$ & $3-$ & $2-$ \\
\hline Hirundo rustica & & & & & & & & $2+\quad 11$ & & & \\
\hline Phoenicurus ochruros & & & & & & & 1 & $1+$ & & & \\
\hline Sorex araneus & & & $2-$ & 1 & 1 & $2-$ & 0 & $2+$ & $3+\quad 66$ & $1+79$ & 18 \\
\hline Sorex minutus & & 1 & 5 & 2 & & $1-$ & 0 & $1+$ & $1+$ & $1+56$ & $1+\quad 15$ \\
\hline Crocidura suaveolens & & 1 & $1-$ & 2 & & & 6 & $1+$ & 3 & $1+77$ & 10 \\
\hline Crocidura leucodon & & 2 & 8 & $1-$ & $1-$ & $1-$ & 6 & 17 & 5 & $1+83$ & 22 \\
\hline Clethrionomys glareolus & & & 1 & & & & & & $2+\quad 18$ & 5 & 1 \\
\hline Mus spicilegus & & & & & 2 & & & 2 & & $2+\quad 64$ & $1-$ \\
\hline Mus cf. musculus & & 3 & 13 & $1-$ & $1-$ & & 13 & $1+51$ & 12 & $1-\quad 30$ & $1+\quad 48$ \\
\hline Micromys minutus & & 1 & & & & & 3 & 6 & 5 & 11 & $1+\quad 12$ \\
\hline Apodemus sylvaticus & & & $1-$ & 1 & & & 2 & 6 & 2 & $2-$ & $2+\quad 30$ \\
\hline Apodemus flavicollis & & & & & 1 & & & 2 & & 6 & 2 \\
\hline Apodemus microps & & & 3 & 2 & & & 3 & $1-$ & 7 & 26 & 7 \\
\hline Columba livia dom. & & & & & & & & & & 2 & \\
\hline Passer montanus & & & & & & & & 1 & & & 1 \\
\hline Mammalia & & 75 & 292 & 89 & 116 & & 254 & 345 & 155 & 1077 & 356 \\
\hline Aves & & 1 & 2- & 0 & 3 & & 8 & $2+$ & 3 & 3- & 2- \\
\hline Amphibia & & 0 & 0 & 0 & 0 & & 0 & 0 & 1 & 0 & 0 \\
\hline $\bar{\Sigma}$ & & 76 & 292 & 89 & 119 & & 262 & 413 & 159 & 1080 & 357 \\
\hline $\mathrm{H}^{\prime}$ & & 0.56 & 0.56 & 0.50 & 0.53 & & 0.84 & 2.17 & 1.92 & 1.66 & 1.66 \\
\hline
\end{tabular}

Locality / lokalita: 6 - Čalovec, Margita, 25.4.1997, leg. Ambros, 8 - Horná Pôtoň, 1.9.1992, leg. Kürthy, 12 - Michal na Ostrove, 25.3.1993, leg. Kürthy, 16 - Tešedlíkovo, 14.9.2002, leg.Sárossy, 17 - Šal'a, 1999, 5 - Dunajská Lužná, 13.7.2004 + 16.4.2005, leg. Lengyel, 7 - Gabčíkovo, 13.1.2001, leg. Lešičko + 20.1.2002, 1 - Bokroš, 24.2.2004 + 24.2.2006, leg. Lengyel + Botková 2011, 2 Bufa, 2000, 10 - Zemianska Olča, 2001, 14 - Palárikovo, 13.9.2002 + 28.11.2004 +24.1.2005, leg. Lengyel, 11 - Lehnice, 1992 , leg. Darolová + 1998, 15 - Rusovce, 1995, 4 - Dropie, 18.4.1996, leg. Antal, 18 - Tvrdošovce, 14.9.2002, leg. Lengyel, 9 - Ivanka pri Dunaji, 12.3.2004, leg. Sárossy, 3 - Diakovce, 21.9.2003, leg. Sárossy, 13 - Nový Trh, 5.3.2004, leg. Sárossy.

Other species (locality-number) / ostatné druhy (lokalita-počet): Neomys anomalus (1-1; 15-1), Myotis dasycneme (1-1), Apodemus sp. (1-16; 15-52), Terricola subterraneus (10-1), Microtus agrestis (8-1; 14-1), Microtus oeconomus (7-1; 10-1), Coturnix coturnix (15-1), Athene noctua (11-1), Alauda arvensis (11-2), Locustella sp. (14-1), Regulus sp. (7-1), Turdus merula (7-1), Parus major (5-1; 7-1; 1-1), Passeriformes (16-2; 15-1), Pelophylax cf. esculentus (7-1; 11-1). 
Slovak Raptor Journal 2016, 10: 1-50. DOI: 10.1515/srj-2016-0003.

(C) Raptor Protection of Slovakia (RPS)

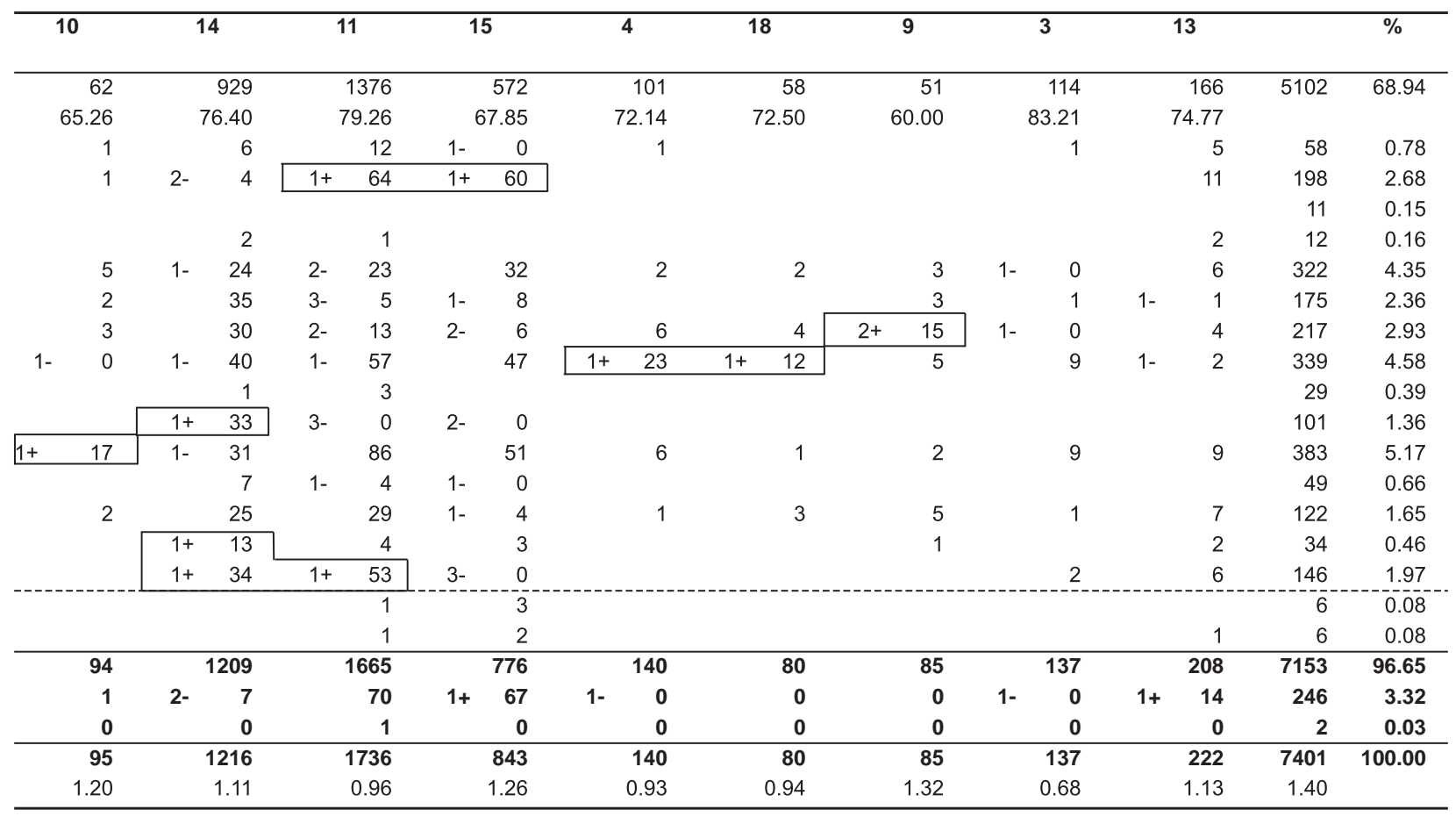




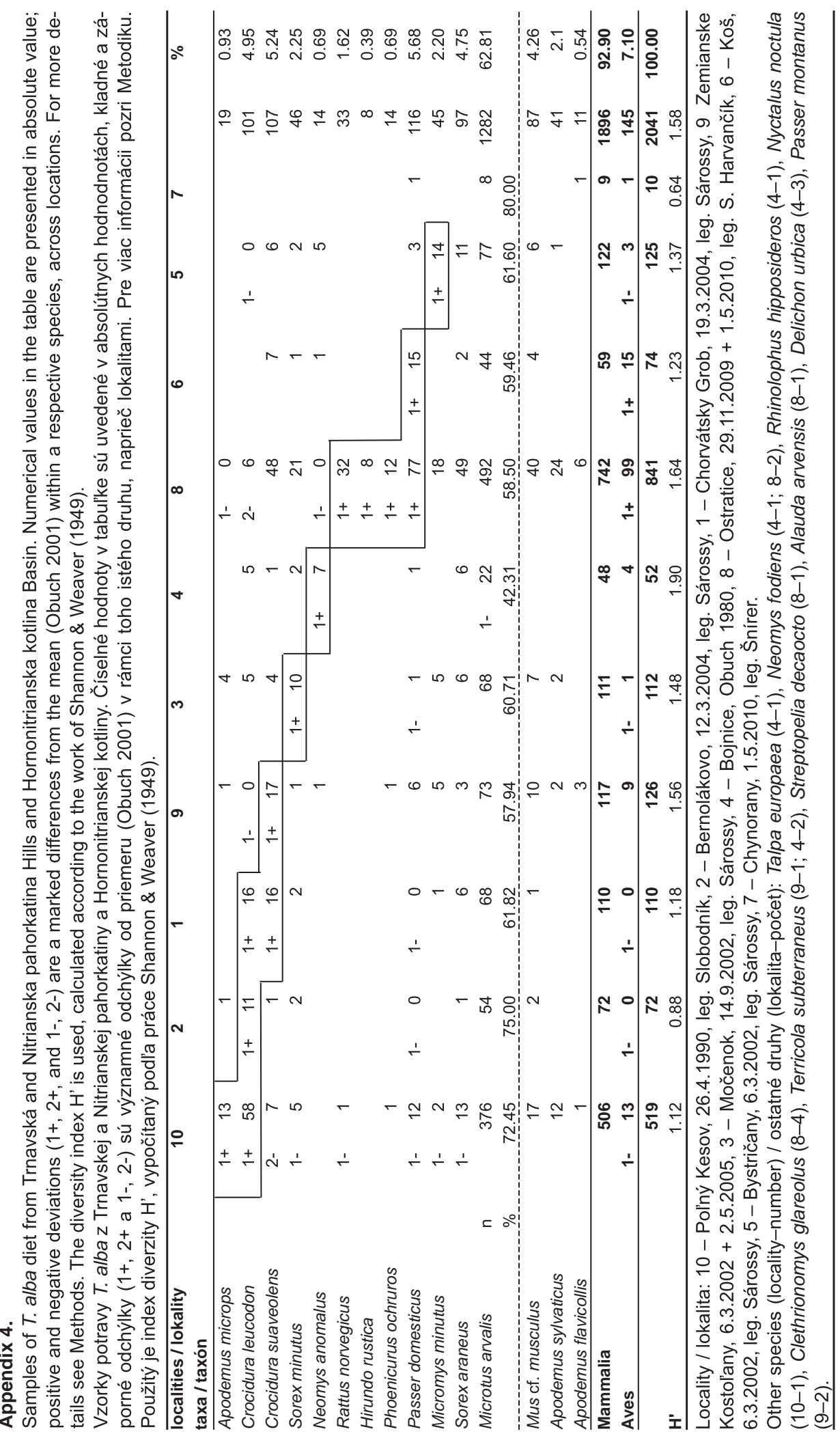




\section{Appendix 5.}

Samples of T. alba diet from Ipel'ská pahorkatina Hills. Numerical values in the table are presented in absolute value; positive and negative deviations $(1+, 2+$, and 1-, 2-) area marked differences from the mean (Obuch 2001) within a respective species, across locations. For more details see Methods. The diversity index $\mathrm{H}^{\prime}$ is used, calculated according to the work of Shannon \& Weaver (1949).

Vzorky potravy T. alba z Ipel'skej pahorkatiny. Číselné hodnoty $v$ tabul'ke sú uvedené v absolútnych hodnodnotách, kladné a záporné odchýlky (1+, 2+ a 1-, 2-) súvýznamné odchýlky od priemeru (Obuch 2001) v rámci toho istého druhu, naprieč lokalitami. Pre viac informácii pozri Metodiku. Použitý je index diverzity H', vypočítaný podla práce Shannon \& Weaver (1949).

\begin{tabular}{|c|c|c|c|c|c|c|c|c|c|c|}
\hline $\begin{array}{l}\text { localities / lokality } \\
\text { taxa / taxón }\end{array}$ & & 4 & 6 & 5 & 1 & 2 & 7 & 3 & $\sum$ & $\%$ \\
\hline Rattus norvegicus & & $2+\quad 11$ & & 1 & 1 & & 1 & 2 & 16 & 0.50 \\
\hline \multirow[t]{2}{*}{ Microtus arvalis } & $\mathrm{n}$ & $1+141$ & $1+258$ & 258 & 539 & $1-189$ & 198 & 133 & 1716 & 53.98 \\
\hline & $\%$ & 69.80 & 80.88 & 59.86 & 62.75 & 26.10 & 44.90 & 65.52 & & \\
\hline Apodemus flavicollis & & 1 & $1+9$ & $1+14$ & $2-\quad 0$ & $2-$ & 6 & 6 & 36 & 1.13 \\
\hline Apodemus sylvaticus & & 1 & 5 & $2+\quad 28$ & $2-$ & $2-$ & 9 & 4 & 47 & 1.48 \\
\hline Apodemus microps & & 1 & 8 & $1+18$ & $2-$ & $2-$ & 9 & & 36 & 1.13 \\
\hline Passer domesticus & & $1-$ & $1-$ & $2-$ & $1+62$ & 32 & 25 & $2-$ & 130 & 4.9 \\
\hline Arvicola amphibius & & & & & $1+10$ & & & & 10 & 0.31 \\
\hline Sorex araneus & & 1- & $2-$ & 3- & $1+102$ & 43 & 26 & $1-$ & 181 & 5.69 \\
\hline Sorex minutus & & 3 & 4 & $2-$ & 21 & $1+42$ & 10 & 3 & 83 & 2.61 \\
\hline Mus cf. musculus & & 12 & $1-$ & 17 & 31 & $1+59$ & 15 & 7 & 146 & 4.59 \\
\hline Pelobates fuscus & & & & & $1-$ & $2+\quad 22$ & & & 22 & 0.69 \\
\hline Crocidura suaveolens & & 11 & $2-$ & 38 & 19 & $1+78$ & $1+$ & 9 & 225 & 7.8 \\
\hline Crocidura leucodon & & 12 & $1-$ & 32 & 20 & $1+102$ & $1+$ & $1+30$ & 257 & 8.8 \\
\hline Terricola subterraneus & & & 1 & 3 & 1 & 4 & $1+$ & & 17 & 0.53 \\
\hline Micromys minutus & & 3 & 2 & 11 & $1-$ & 14 & 10 & 2 & 44 & 1.38 \\
\hline Phoenicurus ochruros & & & 4 & & 2 & 1 & & & 7 & 0.22 \\
\hline Hirundo rustica & & & 2 & & 2 & 1 & & & 5 & 0.16 \\
\hline Mammalia & & 199 & 307 & 425 & 792 & 661 & 414 & 203 & 3001 & 94.40 \\
\hline Aves & & 1- & 12 & $2-$ & $1+66$ & 39 & 27 & 2- & 152 & 4.78 \\
\hline Amphibia & & 0 & 0 & 1 & $1-\quad 1$ & $2+\quad 24$ & 0 & 0 & 26 & 0.82 \\
\hline $\bar{\Sigma}$ & & 202 & 319 & 431 & 859 & 724 & 441 & 203 & 3179 & 100.00 \\
\hline $\mathrm{H}^{\prime}$ & & 1.24 & 0.98 & 1.54 & 1.41 & 2.19 & 1.88 & 1.29 & 1.84 & \\
\hline
\end{tabular}

Locality / lokalita: 4 - Hrkovce, 7.2000, leg. Sárossy, 6 - Slatina, 2.9.2001, leg. Sárossy, 5 - Rybník, 11.2001, leg. Sárossy, 1 Salka, Vondráček, Hošek, 1984, 2 - Pastovce, Darolová (1976), 7 - Malé Kozmálovce, 16.2.2002 + 22.5.2005, leg. Sárossy, 3 Bátovce, 12.8.2002, leg. Sárossy.

Other species (locality-number) / ostatné druhy (lokalita-počet):

Talpa europaea (5-1), Neomys anomalus (6-1; 2-1; 7-1), Neomys fodiens (1-4), Myotis myotis (2-1), Myotis blythii (2-1), Eptesicus serotinus (2-1), Pipistrellus pipistrellus (2-1), Muscardinus avellanarius (5-1; 1-1), Mus spicilegus (4-1; 5-2; 7-1), Apodemus sp. (1-41; 2-124), Clethrionomys glareolus (5-1; 2-1; 3-1), Microtus agrestis (3-1), Delichon urbica (6-1), Erithacus rubecula (5-1), Turdus sp. (2-1), Emberiza citrinella (7-1), Carduelis carduelis (2-1), Passer montanus (2-3; 7-1), Passeriformes (6-1), Rana sp. (1-1; 2-2), Amphibia (5-1). 


\section{Appendix 6.}

Samples of T. alba diet from Hronská pahorkatina Hills. Numerical values in the table are presented in absolute value; positive and negative deviations (1+, 2+, and 1-, 2-) are a marked differences from the mean (Obuch 2001) within a respective species, across locations. For more details see Methods. The diversity index H' is used, calculated according to the work of Shannon \& Weaver (1949).

Vzorky potravy T. alba z Hronskej pahorkatiny. Číselné hodnoty v tabulke sú uvedené v absolútnych hodnodnotách, kladné a záporné odchýlky (1+, 2+ a 1-, 2-) sú významné odchýlky od priemeru (Obuch 2001) v rámci toho istého druhu, naprieč lokalitami. Pre viac informácii pozri Metodiku. Použitý je index diverzity H', vypočítaný podla práce Shannon \& Weaver (1949).

\begin{tabular}{|c|c|c|c|c|c|c|c|c|c|c|}
\hline \multirow{2}{*}{$\begin{array}{l}\text { localities / lokality } \\
\text { taxa / taxón } \\
\text { Coleoptera }\end{array}$} & \multicolumn{2}{|r|}{6} & 8 & 14 & 2 & 19 & 17 & 3 & \multirow[t]{2}{*}{9} & 12 \\
\hline & 1 & 12 & & & & & & & & \\
\hline Microtus arvalis & $\mathrm{n}$ & 5948 & $1+43$ & $1+972$ & 1- 730 & $1-\quad 448$ & 588 & 345 & $1-\quad 116$ & $1-\quad 103$ \\
\hline & $\%$ & 83.07 & 95.56 & 85.34 & 47.40 & 47.46 & 64.26 & 84.35 & 45.85 & 50.49 \\
\hline Neomys anomalus & & 19 & & & $2+\quad 19$ & & 1 & & & \\
\hline Hirundo rustica & 1. & 14 & & & $2+\quad 37$ & 1 & & & & \\
\hline Clethrionomys glareolus & 1. & 4 & & 2 & $1+10$ & $1+$ & 2 & & 1 & \\
\hline Apodemus microps & $1-$ & - 142 & & 19 & $1+$ & $3+223$ & $1+$ & 3- & 4 & 9 \\
\hline Micromys minutus & 1. & 28 & & 6 & $2+$ & $1+\quad 20$ & 13 & 3 & & 2 \\
\hline Sorex minutus & 1. & 27 & & 6 & $1+$ & $2-$ & $1+$ & 10 & 4 & 5 \\
\hline Sorex araneus & 1. & 70 & & $1-$ & $2+\quad 111$ & 3- & $1-$ & $1+$ & 9 & $1+$ \\
\hline Apodemus sylvaticus & 1. & 52 & 1 & $1-$ & $1+$ & $1+\quad 29$ & 1- & $2-$ & $1+$ & $1+$ \\
\hline Mus cf. musculus & 1. & - $\quad 342$ & 1 & 60 & $1+168$ & 3- & 18 & 36 & $2+$ & $1-$ \\
\hline Apodemus flavicollis & 2 & 44 & & $1-$ & $1-\quad 15$ & $1+40$ & 13 & $2-$ & $1+$ & $1+$ \\
\hline Terricola subterraneus & 2 & 0 & & & $1+$ & 1 & & & & 1 \\
\hline Muscardinus avellanarius & & 2 & & 1 & 4 & & & 1 & & \\
\hline Passer montanus & & 7 & & & 5 & 3 & 1 & & & \\
\hline Rattus norvegicus & & 128 & & 22 & $3-$ & $2-$ & $2-$ & $1-$ & 1 & 2 \\
\hline Passer domesticus & $1-$ & 81 & & $2-$ & 34 & $1-$ & $2-$ & 7 & 3 & 1 \\
\hline Phoenicurus ochruros & & 13 & & & 1 & 1 & & & & 1 \\
\hline Mus spicilegus & $5-$ & 0 & & $1-$ & $3-$ & $3+\quad 151$ & $3+\quad 112$ & 2- & $1-$ & \\
\hline Crocidura suaveolens & 2 & 58 & & $2-$ & 28 & $3-$ & $1+$ & $1+$ & 6 & 5 \\
\hline Crocidura leucodon & 1. & $-\quad 125$ & & $2-$ & $1+141$ & $4-$ & 39 & 17 & 12 & $2+$ \\
\hline Cricetus cricetus & & 3 & & & & & & & 2 & \\
\hline Columba livia dom. & & 2 & & & & & & & & \\
\hline Parus major & & & & & & 4 & & & & \\
\hline Talpa europaea & & 2 & & & & & & & & \\
\hline Sturnus vulgaris & & 5 & & & 1 & & & & & \\
\hline Arvicola amphibius & & 1 & & & 2 & & & & & \\
\hline Alauda arvensis & & 2 & & & 1 & & & & & \\
\hline Mammalia & & 7000 & 45 & 1135 & 1459 & 926 & 914 & 501 & 247 & 201 \\
\hline Aves & $1-$ & - 146 & 0 & $2-\quad 3$ & $1+80$ & 18 & 3- & $1-$ & 6 & 3 \\
\hline Amphibia, Reptilia & & 2 & 0 & 1 & 1 & 0 & 0 & 1 & 0 & 0 \\
\hline Invertebrata & & 12 & 0 & 0 & 0 & 0 & 0 & 0 & 0 & 0 \\
\hline $\bar{\Sigma}$ & & 7160 & 45 & 1139 & 1540 & 944 & 915 & 509 & 253 & 204 \\
\hline$\underline{\mathrm{H}^{\prime}}$ & & 0.88 & 0.21 & 0.74 & 1.96 & 1.50 & 1.37 & 1.27 & 1.72 & 1.72 \\
\hline
\end{tabular}

Locality / Iokalita: 6 - Tekovské Lužany, Obuch 2014, 8 - Maláš, Arma, 6.5.2010, leg., det. Tulis, 14 - Nýrovce, 14.7 .2002 + 9.12.2004, leg. Sárossy, 2 - Arad, 29.7.1995, leg. Korňan, 19 - Ket', 10.3.2005, leg. Lengyel, Muránsky, 17 - Bruty, 12.2 .2005$, leg. Lengyel, Muránsky, 3 - Kamenný Most, Vondráček \& Hošek, 1984, 9 - Čaka, 7.5.2010, leg., det. Tulis, 12 - Čifáre, 23.5.2002, leg. Sárossy, 15 - Plavé Vozokany, 5.9.2000, leg. Sárossy + 6.5.2010, leg., det. Tulis + Obuch (2014), 4 - Bíňa, Vondráček \& Hošek (1984), 18 - Farná, 10.3.2005, leg. Lengyel, Muránsky, 16 - Žemliare, 6.2.2002, leg. Sárossy, 20 - Tehla, 19.6.2004, leg. Sárossy, 1 - Ivanovo, 29.7.1995, leg. Korňan, 10 - Beša, 1.8.2001, leg. Sárossy, 13 - Kálnica, 1.8.2001, leg. Sárossy, 11 - Čechy, 5.9.2000, leg. Sárossy, 5 - Čata, Vondráček \& Hošek (1984), 7 - Vel'ký Dvor, 27.8.2010, leg., det. Tulis.

Other species (locality-number) / ostatné druhy (lokalita-počet): Neomys fodiens (3-3), Myotis myotis (6-1; 3-1; 4-1), 
Slovak Raptor Journal 2016, 10: 1-50. DOI: 10.1515/srj-2016-0003.

(C) Raptor Protection of Slovakia (RPS)

\begin{tabular}{|c|c|c|c|c|c|c|c|c|c|c|c|c|c|c|c|c|c|c|c|c|c|}
\hline & 15 & & 4 & & 18 & & 16 & & 20 & & 1 & & 10 & & 13 & 1 & 1 & 5 & 7 & $\sum$ & $\%$ \\
\hline & 3 & & & & & & & & & & & & 1 & & & & & & & 16 & 0.08 \\
\hline & 1870 & & 384 & $1-$ & 169 & & 139 & $1-$ & 183 & & 260 & & 229 & & 383 & & 195 & 89 & 26 & 13,220 & 69.92 \\
\hline & 60.42 & & 74.42 & & 43.90 & & 84.24 & & 50.00 & & 74.07 & & 59.64 & & 72.54 & & 70.65 & 87.25 & 83.87 & & \\
\hline $1-$ & 3 & & & & & & & & 1 & & & & 5 & & & & & & & 48 & 0.25 \\
\hline \multirow[t]{2}{*}{$1-$} & 1 & & & & 2 & & & & 5 & & & & & & & & & & & 60 & 0.32 \\
\hline & 6 & & & & 2 & & & & 1 & & & & & & 1 & & 1 & & & 37 & 0.20 \\
\hline \multirow[t]{4}{*}{$1-$} & 52 & 3- & 0 & & 14 & & 2 & & 1.3 & $2-$ & 1 & & 10 & $1-$ & 8 & & 6 & & & 605 & 3.20 \\
\hline & 31 & & 5 & & 1 & & 2 & & 7 & & 2 & & 6 & & 1 & & 2 & & & 172 & 0.91 \\
\hline & 35 & & 5 & & 3 & & 1 & $1+$ & 13 & & 3 & & 3 & & 8 & & 1 & & 2 & 185 & 0.98 \\
\hline & 50 & & 5 & & 10 & & 1 & & 8 & & 4 & & 3 & & 10 & $1-$ & 0 & & 3 & 333 & 1.76 \\
\hline $1+$ & 90 & $2-$ & 0 & & 6 & & & & 4 & & 2 & & 8 & & 5 & & 5 & & & 309 & 1.63 \\
\hline $1+$ & 313 & & 36 & & 26 & $1-$ & 4 & & 31 & $1-$ & 8 & & 30 & $1-$ & 22 & & 21 & 4 & & 1192 & 6.30 \\
\hline $1+$ & 140 & $2-$ & 0 & & 8 & & 3 & & 8 & & 3 & & 11 & $1-$ & 3 & $2+$ & 24 & & & 347 & 1.84 \\
\hline $1+$ & 20 & & & & 1 & & & & 4 & & & & 1 & & 1 & & & & & 37 & 0.20 \\
\hline $1+$ & 7 & & & & & & & & & & & & & & & & & & & 15 & 0.08 \\
\hline $1+$ & 10 & & & & 1 & & & & & & & & & & & & & & & 27 & 0.14 \\
\hline $1+$ & 83 & $1-$ & 1 & & 5 & & 1 & $2+$ & 22 & $1-$ & 0 & & 9 & $1+$ & 17 & $1-$ & 0 & & & 293 & 1.55 \\
\hline \multirow[t]{2}{*}{$1+$} & 78 & $2+$ & 36 & $2+$ & 46 & & & & 6 & & 3 & & 2 & & 5 & $1-$ & 0 & & & 312 & 1.65 \\
\hline & 2 & & & $1+$ & 8 & & & & 1 & & & & & & & & & & & 27 & 0.14 \\
\hline 4- & 0 & $2-$ & 0 & $2+$ & 28 & $1+$ & 8 & $1+$ & 22 & $1-$ & 0 & $1-$ & 0 & $2-$ & 0 & $1-$ & 0 & & & 327 & 1.73 \\
\hline $1+$ & 93 & & 15 & $1+$ & 16 & & 1 & $1+$ & 16 & $2+$ & 51 & $1+$ & 24 & $1+$ & 27 & $1-$ & 0 & 2 & & 421 & 2.23 \\
\hline \multirow[t]{9}{*}{$1+$} & 188 & $1-$ & 7 & $1+$ & 35 & & 3 & $1+$ & 24 & & 14 & $1+$ & 36 & $1+$ & 35 & $1+$ & 21 & 1 & & 744 & 3.93 \\
\hline & 2 & & & & 3 & & & & & & & & & & & & & & & 10 & 0.05 \\
\hline & 1 & & 2 & & & & & & & & & & & & & & & 4 & & 9 & 0.05 \\
\hline & 2 & & & & & & & & 1 & & & & & & 1 & & & & & 8 & 0.04 \\
\hline & 3 & & & & & & & & & & & & 1 & & & & & & & 6 & 0.03 \\
\hline & & & & & & & & & & & & & & & & & & & & 6 & 0.03 \\
\hline & 1 & & & & & & & & & & & & 1 & & & & & & & 5 & 0.03 \\
\hline & 2 & & & & & & & & & & & & & & & & & & & 5 & 0.03 \\
\hline & 2989 & & 478 & & 328 & & 165 & & 347 & & 348 & & 380 & & 522 & & 276 & 98 & & 18,390 & 97.26 \\
\hline \multirow[t]{5}{*}{$1+$} & 101 & $1+$ & 38 & $2+$ & 57 & $1-$ & 0 & & 15 & $1-$ & 3 & $1-$ & 3 & $1-$ & 6 & 1- & 0 & 4 & 0 & 491 & 2.60 \\
\hline & 1 & & 0 & & 0 & & 0 & & 0 & & 0 & & 0 & & 0 & & 0 & 0 & 0 & 6 & 0.03 \\
\hline & 4 & & 0 & & 0 & & 0 & & 4 & & 0 & & 1 & & 0 & & 0 & 0 & 0 & 21 & 0.11 \\
\hline & 3095 & & 516 & & 385 & & 165 & & 366 & & 351 & & 384 & & 528 & & 276 & 102 & \multicolumn{3}{|c|}{$31 \quad 18,908 \quad 100.00$} \\
\hline & 1.62 & & 1.5 & & 2.3 & & 0.76 & & 1.98 & & 0.97 & & 1.61 & & 1.19 & & 1.8 & 0.57 & 0.55 & $\quad 1.41$ & \\
\hline
\end{tabular}

Eptesicus serotinus (13-1), Nyctalus noctula (6-1; 15-1), Sicista subtilis (6-3), Apodemus agrarius (15-1), Apodemus sp. (3-43; 4-19; 10-3; 5-2), Microtus agrestis (17-1), Microtus oeconomus (2-2), Mustela nivalis (18-1), Coturnix coturnix (6-2), Streptopelia decaocto (6-4), Tyto alba (6-4), Athene noctua (6-1), Apus apus (6-1), Alaudidae (6-1), Delichon urbica (6-2), Motacilla alba (9-1), Hippolais icterina (6-1), Sylvia nisoria (9-1), Sylvia atricapilla (12-1), Erithacus rubecula (2-1; 15-3), Cyanistes caeruleus (19-1; 15-1), Emberiza citrinella (20-1), Fringilla coelebs (20-1), Carduelis carduelis $(6-1 ; 10-1)$, Chloris chloris (6-4), Coccothraustes coccothraustes (15-1), Passeriformes (6-1; 14-1; 9-1), Pelobates fuscus (6-1), Pelophylax cf. esculentus (6-1; 14-1; 2-1), Rana sp. (3-1), Lacerta agilis (15-1), Diptera (15-1), Gryllotalpa gryllotalpa (20-4). 


\section{Appendix 7.}

Samples of T. alba diet from south of Central Slovakia. Numerical values in the table are presented in absolute value; positive and negative deviations $(1+, 2+$, and 1-, 2-) area marked differences from the mean (Obuch 2001) within a respective species, across locations. For more details see Methods. The diversity index $\mathrm{H}^{\prime}$ is used, calculated according to the work of Shannon \& Weaver (1949).

Vzorky potravy T. alba z juhu stredného Slovenska. Číselné hodnoty v tabul'ke sú uvedené v absolútnych hodnodnotách, kladné a záporné odchýlky (1+, 2+ a 1-, 2-) sú významné odchýlky od priemeru (Obuch 2001) v rámci toho istého druhu, naprieč lokalitami. Pre viac informácii pozri Metodiku. Použitý je index diverzity H', vypočítaný podla práce Shannon \& Weaver (1949).

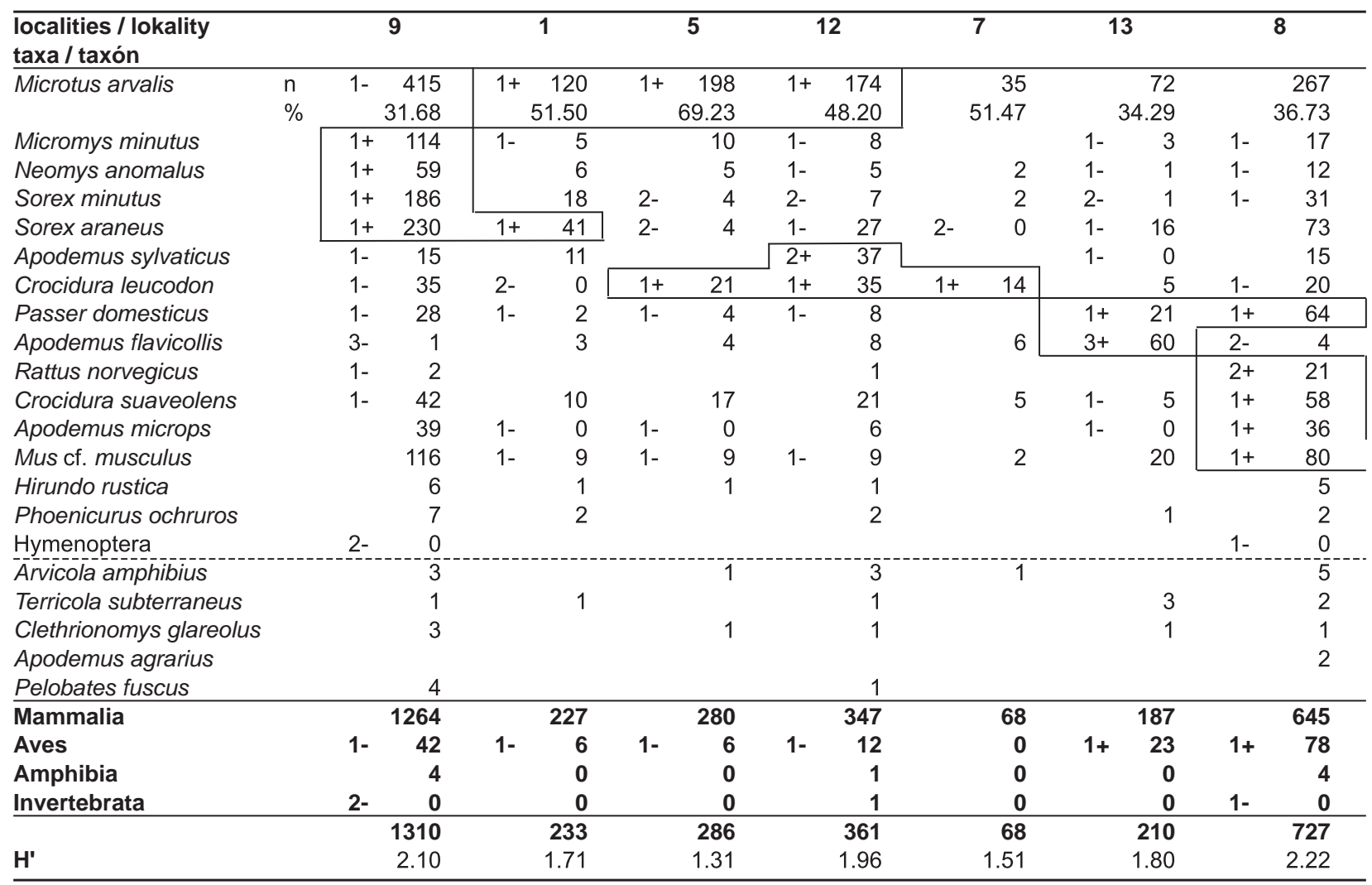

Locality / lokalita: 9 - Pet'ov, 10.8.2000, leg. Sárossy, 1 - Dobrá Niva, 27.7.1995, leg. Uhrin, 5 - Breznička, Obuch \& Uhrin (1997), 12 - Hrabovo, Obuch \& Uhrin (1997, 2001), 7 - Dolná Strehová, Obuch \& Uhrin (1997), 13 - Senné, 9.7.2001, leg. Sárossy, 8 Bušince, Obuch \& Uhrin (1997) + 9.7.2000, leg Sárossy, 2 - Gemerský Jablonec, Darolová 1976, 6 - Dolné Záhorany, 18.5.2002, leg. Sárossy, 3 - Majša, 25.8.2006, leg. Benda, Uhrin, 4 - Malé Dálovce, 24.5.2006, 10 - Selešt’any, 28.11.1998, 11 - Sklabiná, 28.11.1998.

Other species (locality-number) / ostatné druhy (lokalita-počet):

Talpa europaea (1-1), Neomys fodiens (1-1; 12-1), Myotis mystacinus (12-1), Myotis myotis (7-1), Plecotus austriacus (9-2), Muscardinus avellanarius (1-1; 12-2; 11-1), Mustela nivalis (9-1; 8-1), Coturnix coturnix (9-1), Alauda arvensis (12-1; 8-1), Delichon urbica (13-1), Cyanistes caeruleus (3-1), Troglodytes troglodytes (8-2), Passer montanus (8-4), Passeriformes (1-1), Aves sp. juv. (5-1), Pelophylax cf. esculentus (8-4), Coleoptera (12-1; 3-3), Orthoptera (3-1). 
Slovak Raptor Journal 2016, 10: 1-50. DOI: 10.1515/srj-2016-0003.

(C) Raptor Protection of Slovakia (RPS)

\begin{tabular}{|c|c|c|c|c|c|c|c|c|c|}
\hline 2 & & 6 & & 3 & 4 & 10 & 11 & $\sum$ & $\%$ \\
\hline \multirow{2}{*}{$2-$} & & 57 & $1-$ & 16 & 3 & 8 & 11 & 1384 & 38.69 \\
\hline & & 36.08 & & 16.49 & 33.33 & 72.72 & 37.93 & & \\
\hline \multirow[t]{11}{*}{$1+$} & & 12 & & 9 & 1 & & & 193 & 5.40 \\
\hline & & 1 & & 4 & & & & 101 & 2.82 \\
\hline & & 11 & $1-$ & 0 & 1 & & 1 & 266 & 7.44 \\
\hline & $1-$ & 12 & $1-$ & 3 & 4 & 1 & 6 & 432 & 12.8 \\
\hline & & 1 & & & & & 3 & 90 & 2.52 \\
\hline & & 10 & 1- & 0 & & 1 & 2 & 149 & 4.17 \\
\hline & & 9 & & 1 & & & & 140 & 3.91 \\
\hline & & 2 & & 5 & & 1 & & 94 & 2.63 \\
\hline & & 1 & & & & & & 26 & 0.73 \\
\hline & & 10 & & 10 & & & 2 & 187 & 5.23 \\
\hline & & & & & & & 2 & 83 & 2.32 \\
\hline 12 & & 17 & & 4 & & & 1 & 279 & 7.80 \\
\hline & $1+$ & 10 & & 1 & & & & 25 & 0.70 \\
\hline & & 1 & $1+$ & 5 & & & & 20 & 0.56 \\
\hline & & & $3+$ & 29 & & & & 29 & 0.81 \\
\hline & & $\overline{1}$ & & 1 & & & & 15 & 0.42 \\
\hline & & & & 2 & & & & 10 & 0.28 \\
\hline & & 1 & & & & & & 8 & 0.22 \\
\hline & & 2 & & 2 & & & & 6 & 0.17 \\
\hline & & & & & & & & 5 & 0.14 \\
\hline 75 & & 138 & 1- & 56 & 9 & 11 & 29 & 3336 & 93.26 \\
\hline 3 & $1+$ & 20 & & 8 & 0 & 0 & 0 & 198 & 5.54 \\
\hline 0 & & 0 & & 0 & 0 & 0 & 0 & 9 & 0.25 \\
\hline 0 & & 0 & $3+$ & 33 & 0 & 0 & 0 & 34 & 0.95 \\
\hline 78 & & 158 & & 97 & 9 & 11 & 29 & 3577 & 100.00 \\
\hline 2.19 & & 2.17 & & 2.29 & 1.21 & 0.89 & 1.83 & 2.25 & \\
\hline
\end{tabular}




\section{Appendix 8.}

Samples of $T$. alba diet of Rimavská kotlina Basin. Numerical values in the table are presented in absolute value; positive and negative deviations (1+, 2+, and 1-, 2-) area marked differences from the mean (Obuch 2001) within a respective species, across locations. For more details see Methods. The diversity index H' is used, calculated according to the work of Shannon \& Weaver (1949).

Vzorky potravy T. alba z Rimavskej kotliny. Číselné hodnoty v tabul'ke sú uvedené v absolútnych hodnodnotách, kladné a záporné odchýlky (1+, 2+ a 1-, 2-) sú významné odchýlky od priemeru (Obuch 2001) v rámci toho istého druhu, naprieč lokalitami. Pre viac informácii pozri Metodiku. Použitý je index diverzity H', vypočítaný podla práce Shannon \& Weaver (1949).

\begin{tabular}{|c|c|c|c|c|c|c|c|c|c|c|c|c|c|c|c|c|}
\hline \multirow{2}{*}{$\begin{array}{l}\text { localities / lokality } \\
\text { taxa / taxón } \\
\text { Neomys anomalus }\end{array}$} & \multicolumn{2}{|r|}{11} & \multicolumn{2}{|c|}{17} & \multicolumn{2}{|c|}{9} & \multicolumn{2}{|c|}{10} & \multicolumn{2}{|c|}{12} & \multicolumn{2}{|r|}{8} & \multicolumn{2}{|c|}{4} & \multicolumn{2}{|c|}{2} \\
\hline & $1+$ & & & 7 & & 1 & $2-$ & 3 & & & & 14 & & 3 & & 9 \\
\hline Myotis myotis & $1+$ & 29 & & & & & & & & & & & & & & 1 \\
\hline Apodemus sylvaticus & $1+$ & 95 & $2-$ & 0 & & & & 12 & & & $1-$ & 2 & & & & 7 \\
\hline Passer montanus & $1+$ & 22 & & 3 & & & & 2 & & & & & & & & 2 \\
\hline Passer domesticus & $1+$ & $\begin{array}{r}+\quad 265 \\
\end{array}$ & $1+$ & 55 & $1+$ & 8 & $1-$ & 28 & & 2 & $2-$ & 4 & $1-$ & 1 & $1-$ & 11 \\
\hline Crocidura leucodon & & 302 & $1+$ & 151 & & 7 & $1-$ & 36 & $1-$ & 2 & $1-$ & 37 & & 17 & $2-$ & 11 \\
\hline Mus cf. musculus & & 222 & & 61 & $1+$ & 9 & $1+$ & 97 & & 9 & $1-$ & 15 & & 14 & & 28 \\
\hline Apodemus agrarius & $4-$ & 7 & 3- & 0 & & & $1+$ & 72 & $1+$ & 13 & $2+$ & 72 & $1+$ & 13 & & 12 \\
\hline Rattus norvegicus & $1-$ & 21 & $1-$ & 1 & & 4 & $1+$ & 33 & $1+$ & 10 & & 4 & & & $1+$ & 14 \\
\hline Apodemus microps & $1-$ & 112 & 4- & 0 & & 1 & $1+$ & 158 & & 10 & $1+$ & 122 & $1+$ & 31 & $2+$ & 100 \\
\hline Terricola subterraneus & 2- & 2 & $1-$ & 0 & & & $1+$ & 16 & & & & 3 & & 1 & $2+$ & 18 \\
\hline Sorex minutus & $1-$ & 82 & $1-$ & 7 & & & & 24 & & 6 & $1+$ & 35 & $1+$ & 12 & & 12 \\
\hline Apodemus flavicollis & & 57 & $2-$ & 0 & & & $1-$ & 12 & & 3 & $1+$ & 27 & & & $1+$ & 22 \\
\hline Sorex araneus & $1-$ & 270 & $1-$ & 45 & & 3 & & 104 & & 5 & $1+$ & 94 & $1+$ & 36 & $1+$ & 91 \\
\hline Micromys minutus & & 185 & $1-$ & 32 & & 4 & & 48 & & 3 & & 38 & $1+$ & 19 & & 21 \\
\hline Crocidura suaveolens & $1-$ & 99 & $1-$ & 37 & $1+$ & 11 & $1-$ & 43 & $1+$ & 13 & & 51 & $2+$ & 49 & $1-$ & 18 \\
\hline \multirow[t]{2}{*}{ Microtus arvalis } & $\mathrm{n}$ & 3344 & & 699 & $1-$ & 12 & & 772 & & 59 & $1-$ & 436 & $2-$ & 50 & $1-$ & 324 \\
\hline & $\%$ & 63.41 & & 58.79 & & 19.67 & & 51.02 & & 43.38 & & 43.13 & & 20.16 & & 43.90 \\
\hline Arvicola amphibius & & 7 & & & & & & 1 & & & & 2 & & & & 3 \\
\hline Hirundo rustica & & 7 & & & & & & & & & & & & & & 1 \\
\hline Muscardinus avellanarius & & 2 & & & & & & 1 & & & & 4 & & & & 1 \\
\hline Alauda arvensis & & 5 & & & & & & & & & & 1 & & & & 2 \\
\hline Eptesicus serotinus & & 3 & & & & & & 1 & & & & & & & & 1 \\
\hline Nyctalus noctula & & 3 & & & & & & & & & & 3 & & & & 1 \\
\hline Phoenicurus ochruros & & 1 & & 1 & & 1 & & 1 & & & & 2 & & & & 1 \\
\hline Talpa europaea & & 2 & & 1 & & & & & & & & & & & & \\
\hline Neomys fodiens & & & & & & & & & & & & 4 & & 1 & & 1 \\
\hline Coleoptera & & 3 & & & & & & & & & & & & & & 3 \\
\hline Delichon urbica & & 3 & & & & & & & & & & 1 & & & & \\
\hline Mammalia & & 4947 & & 1121 & & 52 & & 1477 & & 133 & & 991 & & 246 & & 715 \\
\hline Aves & $1+$ & $+\quad 317$ & & 61 & $1+$ & 9 & 1- & 34 & & 3 & 1- & 19 & $1-$ & 2 & $1-$ & 18 \\
\hline Amphibia & & 6 & $1+$ & 7 & & 0 & & 0 & & 0 & & 1 & & 0 & & 2 \\
\hline Invertebrata & & 4 & & 0 & & 0 & & 2 & & 0 & & 0 & & 0 & & 3 \\
\hline$\sum$ & & 5274 & & 1189 & & 61 & & 1513 & & 136 & & 1011 & & 248 & & 738 \\
\hline $\mathbf{H}^{\prime}$ & & 1.61 & & 1.52 & & 2.13 & & 1.90 & & 1.96 & & 2.9 & & 2.17 & & 2.11 \\
\hline
\end{tabular}

Locality / lokalita: 11 - Rinavské Janovce, Darolová (1976 ), Obuch (1995) + 7.2.2002, leg. Sárossy, 17 - Číž, Darolová (1977), 9 Malé Teriakovce, 19.4.2002, leg. Sárossy, 10 - Radnovce, 3.7.2002 + 15.10.2004, leg. Sárossy, 12 - Rumince, 18.5 .2010 , leg. D. Obuch, 8 - Lenka, 19.7.2001 + 15.10.2004, leg. Sárossy, 4 - Chanava, 19.4.2002, leg. Sárossy, 2 - Behynce, 10.7.2001, leg. Uhrin \& Benda + 15.10.2004, leg Sárossy, 3 - Bátka, 18.4.2002, leg. Sárossy, 7 - Levkuška, 11.7.2001, leg. Uhrin \& Benda, 1 - Bottovo, 3.4.2004, leg. Sárossy, 13 - Rakytník, 28.6.2004, leg. Sárossy, 15 - Vel'ký Blh, 14.8.1997, leg Uhrin \& Benda + 18.4.2002, leg. Sárossy, 6 - Gortva, 6.7.2002, leg. Sárossy, 14 - Uzovská Panica, 1.8.2001, leg. Uhrin \& Benda, 16 - Gemerská Ves, 10.7 .2001 , leg. Uhrin \& Benda, 5 - Dubovec, 3.12.2001, leg. Sárossy.

Other species (locality-number) / ostatné druhy (lokalita-počet):

Myotis mystacinus (2-1), Myotis blythii (11-1), Pipistrellus nathusii (10-1), Plecotus austriacus (17-1; 2-1), Apodemus sp. (11-28; 
Slovak Raptor Journal 2016, 10: 1-50. DOI: 10.1515/srj-2016-0003.

(C) Raptor Protection of Slovakia (RPS)

\begin{tabular}{|c|c|c|c|c|c|c|c|c|c|c|c|c|c|c|c|c|c|c|}
\hline & 3 & & 7 & & 1 & & 13 & & & & 6 & & 14 & & 16 & 5 & $\bar{\Sigma}$ & $\%$ \\
\hline & & & 1 & & & & & & 6 & & 2 & & & & & & 119 & 1.40 \\
\hline & & & & & & & & & & & & & & & & & 30 & 0.26 \\
\hline & & & 3 & & & & 2 & & 2 & & 7 & & 1 & & 2 & 2 & 135 & 1.18 \\
\hline & & & & & & & & & & & & & & & & & 29 & 0.25 \\
\hline & 1 & $1-$ & 0 & & 3 & $1-$ & 0 & $2-$ & 0 & & 3 & $1-$ & 0 & & & & 381 & 3.33 \\
\hline & & & 3 & & 4 & & 15 & & 20 & $1+$ & 20 & & 5 & & 3 & 6 & 639 & 5.59 \\
\hline & 4 & & 4 & & 4 & & 8 & $1-$ & 2 & & 13 & $1-$ & 1 & & & 1 & 492 & 4.31 \\
\hline & & $1+$ & 10 & $1+$ & 9 & & 2 & & 3 & & 6 & & 6 & & 3 & 1 & 229 & 2.00 \\
\hline & & $1+$ & 9 & & & & 1 & & & & & & 1 & & 1 & & 99 & 0.87 \\
\hline & 4 & & 2 & & 3 & & 10 & & 14 & $1-$ & 5 & & 8 & & 1 & 3 & 584 & 5.11 \\
\hline & & & & & & & 4 & & 2 & & 1 & & & & & & 47 & 0.41 \\
\hline & 1 & & 1 & & 1 & $1+$ & 13 & & 8 & & 7 & & 6 & & 3 & 4 & 222 & 1.94 \\
\hline $1+$ & 5 & & & & 1 & & 2 & & 5 & & 7 & & 3 & & 2 & 2 & 148 & 1.30 \\
\hline & 8 & $1-$ & 4 & & 5 & $1+$ & 39 & $1+$ & 32 & $2+$ & 46 & & 15 & & 6 & 3 & 806 & 7.50 \\
\hline & & $2+$ & 31 & $1+$ & 11 & $1+$ & 15 & & 5 & & 5 & & 7 & & 3 & 3 & 430 & 3.76 \\
\hline & 1 & $2+$ & 35 & $1+$ & 14 & $1+$ & 23 & $1+$ & 27 & $1+$ & 18 & $1+$ & 17 & & 4 & 6 & 466 & 4.8 \\
\hline $1-$ & 18 & $2-$ & 22 & & 50 & 1- & 97 & & 115 & $1-$ & 69 & & 75 & $1-$ & 17 & 59 & 6218.05 & 54.41 \\
\hline & 36.73 & & 17.60 & & 47.62 & & 41.45 & & 46.37 & & 32.09 & & 51.37 & & 36.96 & 65.56 & & \\
\hline & & & & & & & & & 2 & & 1 & & & & & & 16 & 0.14 \\
\hline & 4 & & & & & & & & 1 & & & & & & & & 13 & 0.11 \\
\hline & & & & & & & 1 & & & & 1 & & & & & & 10 & 0.09 \\
\hline & & & & & & & & & & & & & & & & & 8 & 0.07 \\
\hline & & & & & & & 2 & & & & & & & & & & 7 & 0.06 \\
\hline & & & & & & & & & & & & & & & & & 7 & 0.06 \\
\hline & & & & & & & & & & & & & & & & & 7 & 0.06 \\
\hline & 2 & & & & & & & & & & 1 & & & & & & 6 & 0.05 \\
\hline & & & & & & & & & & & & & & & & & 6 & 0.05 \\
\hline & & & & & & & & & & & & & & & & & 6 & 0.05 \\
\hline & & & & & & & & & 1 & & & & & & & & 5 & 0.04 \\
\hline & 43 & & 125 & & 102 & & 234 & & 243 & & 211 & & 145 & & 45 & 90 & 10,9209 & 95.55 \\
\hline & 6 & 1- & 0 & & 3 & 2- & 0 & $1-$ & 4 & 1- & 4 & 1- & 0 & & 1 & 0 & 481 & 4.21 \\
\hline & 0 & & 0 & & 0 & & 0 & & 1 & & 0 & & 0 & & 0 & 0 & 17 & 0.15 \\
\hline & 0 & & 0 & & 0 & & 0 & & 0 & & 0 & & 1 & & 0 & 0 & 10 & 0.09 \\
\hline & 49 & & 125 & & 105 & & 234 & & 248 & & 215 & & 146 & & 46 & 90 & 11,4281 & 100.00 \\
\hline & 1.96 & & 1.94 & & 1.75 & & 1.93 & & 1.91 & & 2.17 & & 1.73 & & 2.8 & 1.39 & 1.92 & \\
\hline
\end{tabular}

17-78; 10-42; 8-28; 2-17; 6-2), Clethrionomys glareolus (11-1; 17-1; 10-1), Mustela nivalis (2-1), Columba livia dom. (10-2), Streptopelia decaocto (11-1), Tyto alba (11-1; 2-1), Apus apus (11-1; 15-1), Galerida cristata (10-1), Anthus trivialis (11-1), Acrocephalus palustris (8-1; 15-1), Erithacus rubecula (11-1), Luscinia megarhynchos (8-3), Turdus merula (11-3), Turdus sp. (17-1), Parus major (11-1), Sitta europaea (12-1), Troglodytes troglodytes (11-1), Emberiza citrinella (16-1), Carduelis carduelis (11-1), Linaria cannabina (11-1), Chloris chloris (17-1; 4-1), Passeriformes (11-1; 8-7; 3-1; 6-1), Aves sp. juv. (11-1), Pelobates fuscus (11-3), Rana temporaria (2-1), Pelophylax cf. esculentus (11-2; 2-1; 15-1), Rana sp. (11-1; 17-7; 8-1), Gryllotalpa gryllotalpa (10-2; 14-1), Limacidae (11-1). 


\section{Appendix 9.}

Samples of T. alba diet from Revúcka vrchovina Upland. Numerical values in the table are presented in absolute value; positive and negative deviations (1+, 2+, and 1-, 2-) are a marked differences from the mean (Obuch 2001) within a respective species, across locations. For more details see Methods. The diversity index H' is used, calculated according to the work of Shannon \& Weaver (1949).

Vzorky potravy T. alba z Revúckej vrchoviny. Číselné hodnoty $v$ tabul'ke sú uvedené v absolútnych hodnodnotách, kladné a záporné odchýlky (1+, 2+ a 1-, 2-) sú významné odchýlky od priemeru (Obuch 2001) v rámci toho istého druhu, naprieč lokalitami. Pre viac informácii pozri Metodiku. Použitý je index diverzity H', vypočítaný podla práce Shannon \& Weaver (1949).

\begin{tabular}{|c|c|c|c|c|c|c|c|c|c|c|c|c|c|c|c|}
\hline \multirow{2}{*}{$\begin{array}{l}\text { localities / lokality } \\
\text { taxa / taxón } \\
\text { Arvicola amphibius }\end{array}$} & \multirow{4}{*}{$\begin{array}{l}\mathrm{n} \\
\%\end{array}$} & \multicolumn{2}{|r|}{11} & & 15 & \multicolumn{2}{|r|}{4} & \multicolumn{2}{|r|}{10} & & 13 & & 8 & \multicolumn{2}{|r|}{7} \\
\hline & & $1+$ & 6 & & & & & & 10 & & & & & & \\
\hline Microtus arvalis & & $1+$ & 119 & $1+$ & 36 & $1+$ & 106 & $1+$ & 489 & $1+$ & 78 & & 64 & $1-$ & 119 \\
\hline & & & 77.27 & & 63.16 & & 54.64 & & 63.42 & & 55.71 & & 35.36 & & 30.67 \\
\hline Mus cf. musculus & & $1-$ & 0 & & & & 8 & $2-$ & 4 & $1+$ & 10 & $1+$ & 12 & $2+$ & 48 \\
\hline Apodemus agrarius & & & & & 1 & & 6 & $1+$ & 48 & & & $1+$ & 15 & $1+$ & 17 \\
\hline Apodemus microps & & & & & & & & & & & & $1+$ & 6 & $1+$ & 7 \\
\hline Rattus norvegicus & & & & & & & 1 & & 2 & & & $1+$ & 6 & & 1 \\
\hline Hirundo rustica & & & & & & & & & & & & $1+$ & 6 & & 3 \\
\hline Phoenicurus ochruros & & & & & & & 1 & & 1 & & & $1+$ & 5 & & 1 \\
\hline Passer domesticus & & & & & & & 3 & $2-$ & 1 & & 5 & & 1 & $1+$ & 12 \\
\hline Crocidura suaveolens & & & 6 & & 1 & & 7 & $1-$ & 20 & $1-$ & 1 & & 14 & $2+$ & 75 \\
\hline Coleoptera & & & & & & & & & & & & & & & \\
\hline Crocidura leucodon & & & 7 & $1+$ & 15 & & 21 & $1-$ & 33 & $1-$ & 2 & & 11 & $1-$ & 20 \\
\hline Myotis myotis & & $3-$ & 0 & $1-$ & 0 & $3-$ & 1 & $4-$ & 5 & $2-$ & 0 & $3-$ & 0 & 4- & 0 \\
\hline Myotis blythii & & & & & & & & & & & & & & & \\
\hline Apus apus & & & 1 & & & & & & & & 1 & & & & \\
\hline Sorex minutus & & & 2 & & & & 7 & $1-$ & 5 & & 6 & & 2 & & 9 \\
\hline Sorex araneus & & $1-$ & 2 & & & & 8 & $2-$ & 14 & & 9 & & 15 & & 28 \\
\hline Neomys fodiens & & & & & & & & & & & 3 & & 2 & & \\
\hline Micromys minutus & & & 1 & & 2 & & 3 & & 18 & & 5 & & 4 & & 11 \\
\hline Apodemus sylvaticus & & & & & 2 & & & & 11 & & 5 & & 5 & & 8 \\
\hline Apodemus flavicollis & & $1-$ & 5 & $1-$ & 0 & & 19 & & 91 & & 13 & $1-$ & 7 & $1-$ & 24 \\
\hline Clethrionomys glareolus & & & & & & & & & 1 & & & & & & \\
\hline Neomys anomalus & & & -5 & & & & 1 & & 5 & & 2 & & 4 & & 4 \\
\hline Muscardinus avellanarius & & & & & & & & & 3 & & & & 2 & & \\
\hline Terricola subterraneus & & & & & & & & & 2 & & & & & & \\
\hline Nyctalus noctula & & & & & & & & & 1 & & & & & & \\
\hline Passer montanus & & & & & & & & & & & & & & & \\
\hline Mammalia & & & 153 & & 57 & & 189 & & 764 & & 134 & & 169 & & 371 \\
\hline Aves & & & 1 & & 0 & & 4 & 2- & 6 & & 6 & $1+$ & 12 & & 17 \\
\hline Amphibia & & & 0 & & 0 & & 1 & & 0 & & 0 & & 0 & & 0 \\
\hline Invertebrata & & & 0 & & 0 & & 0 & & 1 & & 0 & & 0 & & 0 \\
\hline $\bar{\Sigma}$ & & & 154 & & 57 & & 194 & & 771 & & 140 & & 181 & & 388 \\
\hline $\mathrm{H}^{\prime}$ & & & 0.99 & & 1.2 & & 1.70 & & 1.49 & & 1.68 & & 2.34 & & 2.17 \\
\hline
\end{tabular}

Locality / lokalita: 11 - Ratkovská Lehota, Obuch (2000), 15 - Hucín, 22.7.1995, 4 - Licince, 24.7.2001, 10 - Prihradzany, 30.8.1992, leg. Uhrin + 13.11.2002, 13 - Teplý Vrch, Obuch 2000, 8 - Nižná Pokoradz, 1.8.2001, 7 - Nižná Kaloša, 1.8.2001, 14 Višňové, Obuch (2000), 2 - Budíkovany, Obuch (2000), 9 - Otročok, 11.7.2001, 3 - Gemerský Milhost', 4.3.1997, 1 - Ratková, Obuch $(2000)+27.6 .2000+1.3 .2001$, leg. Petrželková + 10.6.2002 + 27.7.2010, 12 - Šivetice, 30.8.1992, leg Uhrin, 5 - Lipovec, Obuch (2000), 6 - Nandraž, 14.7.1997.

Other species (locality-number) / ostatné druhy (lokalita-počet):

Rhinolophus hipposideros (1-1; 6-3), Rhinolophus euryale (5-1), Myotis mystacinus (1-1), Myotis brandtii (1-1), Myotis 
Slovak Raptor Journal 2016, 10: 1-50. DOI: 10.1515/srj-2016-0003.

(C) Raptor Protection of Slovakia (RPS)

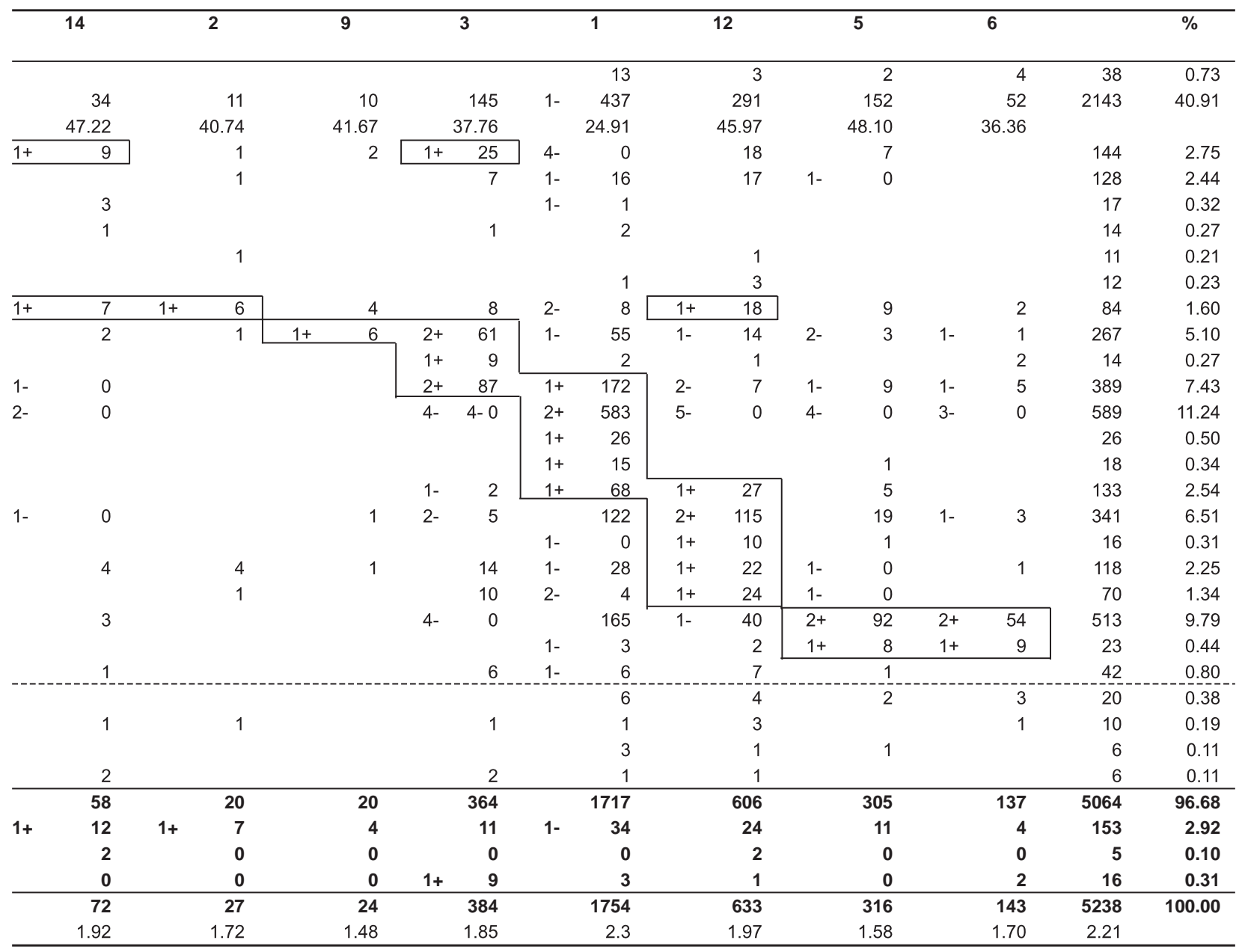

emarginatus (1-1; 5-1), Eptesicus serotinus (5-1), Pipistrellus pipistrellus (4-1; 1-1), Barbastella barbastellus (6-1), Chiroptera (12-1), Microtus agrestis (10-2; 1-1), Coturnix coturnix (10-1), Columba livia dom. (1-2), Athene noctua (14-1), Alauda arvensis (14-1; 1-1), Delichon urbica (14-1; 1-1), Riparia riparia (1-1; 6-1), Motacilla alba (6-1), Muscicapa striata (1-1), Parus major (7-1; 1-2), Sitta europaea (3-1; 1-1), Emberiza citrinella (12-1), Coccothraustes coccothraustes (10-1), Passeriformes (10-2; 5-1), Rana temporaria (14-2), Pelophylax cf. esculentus (4-1; 12-2), Gryllotalpa gryllotalpa (1-1), Orthoptera (10-1). 


\section{Appendix 10.}

For Appendix 10 see page 40.

Appendix 10 je na strane 40 .

\section{Appendix 11.}

Samples of $T$. alba diet from Košická kotlina Basin. Numerical values in the table are presented in absolute value; positive and negative deviations $(1+, 2+$, and 1-, 2-) are a marked differences from the mean (Obuch 2001) within a respective species, across locations. For more details see Methods. The diversity index $H^{\prime}$ is used, calculated according to the work of Shannon \& Weaver (1949). Vzorky potravy $T$. alba z Košickej kotliny. Číselné hodnoty $v$ tabul'ke sú uvedené $v$ absolútnych hodnodnotách, kladné a záporné odchýlky (1+, 2+ a 1-, 2-) sú významné odchýlky od priemeru (Obuch 2001) v rámci toho istého druhu, naprieč lokalitami. Pre viac informácii pozri Metodiku. Použitý je index diverzity H', vypočítaný podla práce Shannon \& Weaver (1949).

\begin{tabular}{|c|c|c|c|c|c|c|c|c|c|c|c|c|c|c|c|c|}
\hline \multirow{2}{*}{$\begin{array}{l}\text { localities / lokality } \\
\text { taxa / taxón } \\
\text { Microtus arvalis }\end{array}$} & \multirow{3}{*}{$\begin{array}{l}\mathrm{n} \\
\%\end{array}$} & \multicolumn{2}{|c|}{1} & 3 & 15 & 18 & \multicolumn{2}{|c|}{13} & \multicolumn{2}{|c|}{14} & \multicolumn{2}{|c|}{6} & \multicolumn{2}{|c|}{20} & \multicolumn{2}{|c|}{2} \\
\hline & & $1+$ & 246 & 57 & 44 & $1+133$ & $1+$ & 244 & & 137 & & 42 & & 66 & & 127 \\
\hline & & & 7.12 & 91.94 & 80.00 & 68.56 & & 74.85 & & 5.69 & & & & 0.00 & & 1.06 \\
\hline Crocidura leucodon & & $2-$ & 1 & 2 & 2 & 9 & & 15 & & 4 & $1+$ & 8 & $1+$ & 12 & & 8 \\
\hline Sorex minutus & & & 5 & & & 3 & $1-$ & 1 & & 3 & & & & 3 & $1+$ & 13 \\
\hline Sorex araneus & & $1-$ & 6 & & & 9 & $1-$ & 6 & $1-$ & 3 & & 1 & & 6 & & 10 \\
\hline Terricola subterraneus & & & & & & & & & & & & & & 1 & & 1 \\
\hline Talpa europaea & & & & & & & & & & & & & & & & \\
\hline Apodemus microps & & & 4 & & & $1-$ & $1-$ & 0 & $1-$ & 0 & & & & 3 & & 7 \\
\hline Passer domesticus & & & 15 & & & 9 & $2-$ & 0 & $1-$ & 0 & & 2 & & & & 10 \\
\hline Pelobates fuscus & & & & & & 1 & & & & & & & & & & \\
\hline Gryllotalpa gryllotalpa & & & & & & & & & & & & & & & & \\
\hline Mus cf. musculus & & $1-$ & 8 & 1 & 3 & $1-$ & $1-$ & 10 & & 17 & & 2 & $1-$ & 4 & $2-$ & 2 \\
\hline Apodemus sylvaticus & & & 2 & & & & $1-$ & 0 & & & & & & 2 & & 7 \\
\hline Apodemus flavicollis & & $1-$ & 2 & & & $1-$ & $2-$ & 0 & 1- & 0 & & 1 & & 1 & & 2 \\
\hline Apodemus agrarius & & & 7 & & 3 & 4 & 1- & 3 & & 1 & & & & 1 & & 8 \\
\hline Micromys minutus & & & 14 & 1 & & 3 & $1-$ & 5 & & 3 & & 1 & & 5 & & 6 \\
\hline Crocidura suaveolens & & $1-$ & 1 & 1 & & 4 & & 5 & & 3 & & & & 4 & & 5 \\
\hline Neomys anomalus & & & 1 & & 1 & & & 1 & & & & & & & & \\
\hline Neomys fodiens & & & 1 & & 1 & & & & & & & & & & & \\
\hline Passer montanus & & & & & & 1 & & & & & & 1 & & & & \\
\hline Coleoptera & & & 3 & & & & & & & & & & & & & \\
\hline Rattus norvegicus & & & 1 & & & & & & & & & & & & & \\
\hline Clethrionomys glareolus & & & 1 & & & & & & & & & & & & & 1 \\
\hline Arvicola amphibius & & & & & & & & & & & & & & 1 & & \\
\hline Alauda arvensis & & & & & & & & & & & & & & & & \\
\hline Hirundo rustica & & & & & & & & & & & & & & 1 & & \\
\hline Mammalia & & & 300 & 62 & 55 & 183 & & 326 & & 181 & & 55 & & 109 & & 198 \\
\hline Aves & & & 16 & 0 & 0 & 10 & 2- & 0 & 2- & 0 & & 5 & & 1 & & 10 \\
\hline Amphibia & & & 0 & 0 & 0 & 1 & & 0 & & 0 & & 0 & & 0 & & 0 \\
\hline Invertebrata & & & 3 & 0 & 0 & 0 & & 0 & & 0 & & 0 & & 0 & & 0 \\
\hline $\bar{\Sigma}$ & & & 319 & 62 & 55 & 194 & & 326 & & 181 & & 60 & & 110 & & 208 \\
\hline$H^{\prime}$ & & & 1.9 & 0.39 & 0.83 & 1.31 & & 0.99 & & 0.98 & & 15 & & 1.57 & & 1.60 \\
\hline
\end{tabular}

Locality / lokalita: 1 - Budulov, Obuch \& Matis (1998), 3 - Cestice, Obuch \& Matis (1998), 15 - Vyšná Myšl'a, Danko \& Štollmann (1977), 18 - Trstené pri Hornáde, Danko \& Štollmann (1977) + Obuch \& Matis (1998), 13 - Kechnec, Danko \& Štollmann (1977), 14 - Gyňov, Danko \& Štollmann (1977), 6 - Vyšný Čaj, Obuch \& Matis (1998), 20 - Nižný Lánec, Obuch \& Matis (1998), 2 - Janík, Obuch \& Matis (1998), 11 - Košická Polianka, 5.1.2004, leg. Sárossy, 19 - Košické Olšany, Obuch \& Matis (1998), 16 - Seňa, Danko \& Štollmann (1977) + Obuch \& Matis (1998), 7 - Sady nad Torysou, Obuch \& Matis (1998), 12 - Milhošt', Danko \& Štollmann (1977), 9 - Král'ovce, Obuch \& Matis (1998), 10 - Brestov, Obuch \& Matis (1998), 4 - Paňovce, Obuch \& Matis (1998), 8 - Bidovce, Obuch \& Matis (1998), 17 - Belža, Danko \& Štollmann (1977) + Obuch \& Matis (1998), 5 - Valaliky, Obuch \& Matis (1998). 
Slovak Raptor Journal 2016, 10: 1-50. DOI: 10.1515/srj-2016-0003.

(C) Raptor Protection of Slovakia (RPS)

\begin{tabular}{|c|c|c|c|c|c|c|c|c|c|c|c|c|c|}
\hline 11 & 19 & 16 & & 7 & 12 & 9 & 10 & 4 & 8 & 17 & 5 & $\bar{\Sigma}$ & $\%$ \\
\hline $1-\quad 13$ & $1-\quad 24$ & $1-352$ & 1- & 19 & 11 & 115 & 164 & 1- 108 & 22 & 49 & 3 & 1976 & 54.65 \\
\hline 19.12 & 26.67 & 42.46 & & 29.69 & 42.31 & 51.80 & 46.46 & 38.99 & 42.31 & 45.372 & 25.00 & & \\
\hline 2 & 1 & 40 & & 1 & & 9 & 20 & 12 & & $1-$ & & 146 & 4.4 \\
\hline$\overline{1+}$ & 5 & 19 & & 1 & & 2 & 6 & 12 & 4 & 1 & 1 & 88 & 2.43 \\
\hline \multirow{7}{*}{$\frac{14}{3}$} & $2+\quad 33$ & $1+68$ & & 4 & & 8 & 17 & $1-$ & 4 & 11 & & 209 & 5.78 \\
\hline & $1+6$ & $1-\quad 0$ & & 1 & & 1 & 3 & 1 & 3 & 4 & & 24 & 0.66 \\
\hline & & $1+8$ & & & & 1 & & & & & & 9 & 0.25 \\
\hline & & $1+\quad 50$ & & 1 & & 10 & $1-$ & $1-$ & 1 & 2 & 2 & 86 & 2.38 \\
\hline & & $1+64$ & $1+$ & 9 & & $1-$ & $1-$ & 12 & & & 1 & 128 & 3.54 \\
\hline & & $1+\quad 9$ & $1+$ & 5 & & & & & & & & 15 & 0.41 \\
\hline & & & $1+$ & 5 & & & 2 & & & & & 7 & 0.19 \\
\hline \multirow[t]{3}{*}{10} & 3 & $1+87$ & & 9 & $1+12$ & $1+36$ & $1+57$ & $1-\quad 12$ & 1 & 7 & & 290 & 8.2 \\
\hline & 5 & 1.6 & & & & 2 & $1+\quad 16$ & 5 & 1 & 3 & & 49 & 1.36 \\
\hline & & 3.1 & & & & 5 & $1+\quad 23$ & $3+57$ & & 3 & 1 & 96 & 2.65 \\
\hline \multirow[t]{2}{*}{2} & 3 & 16 & & & & 9 & 7 & $1+\quad 15$ & 3 & 2 & 2 & 86 & 2.38 \\
\hline & 3 & 36 & & & 3 & 9 & 18 & 1- 5 & $1+$ & $1+\quad 17$ & & 138 & 3.82 \\
\hline \multirow[t]{2}{*}{5} & 1 & 13 & & 3 & & 6 & 8 & 6 & 2 & 6 & & 73 & 2.2 \\
\hline & 2 & 3 & & & & & 5 & & & 1 & & 14 & 0.39 \\
\hline \multirow[t]{3}{*}{1} & 1 & & & & & 3 & 2 & & 1 & & & 10 & 0.28 \\
\hline & & 6 & & & & & & 1 & & & & 9 & 0.25 \\
\hline & & 6 & & & & & & & & & & 9 & 0.25 \\
\hline \multirow[t]{4}{*}{2} & & 2 & & 1 & & & & 2 & & & & 8 & 0.22 \\
\hline & 1 & & & & & & 1 & 3 & & 1 & & 8 & 0.22 \\
\hline & & 5 & & & & & & 1 & & & & 7 & 0.19 \\
\hline & & 2 & & & & 1 & 1 & 2 & & & & 6 & 0.17 \\
\hline 2 & & & & & & & & 2 & & & & 5 & 0.14 \\
\hline 64 & 90 & 730 & 1- & 45 & 26 & 216 & 348 & 252 & 52 & 108 & 10 & 3410 & 94.30 \\
\hline 4 & $1-$ & $1+\quad 78$ & $1+$ & 9 & 0 & 6 & 2- & $1+\quad 25$ & 0 & $1-$ & 2 & 169 & 4.67 \\
\hline 0 & 0 & $1+\quad 15$ & $1+$ & 5 & 0 & 0 & 0 & 0 & 0 & 0 & 0 & 21 & 0.58 \\
\hline 0 & 0 & 6 & $1+$ & 5 & 0 & 0 & 2 & 0 & 0 & 0 & 0 & 16 & 0.44 \\
\hline 68 & 90 & 829 & & 64 & 26 & 222 & 353 & 277 & 52 & 108 & 12 & 3616 & 100.00 \\
\hline 2.26 & 1.95 & 2.17 & & 2.26 & 0.97 & 1.79 & 1.90 & 2.17 & 1.90 & 1.86 & 1.98 & 1.95 & \\
\hline
\end{tabular}

Other species (locality-number) / ostatné druhy (lokalita-počet):

Myotis myotis (16-1; 7-2), Myotis blythii (7-1), Eptesicus serotinus (19-1; 7-1; 5-1), Plecotus austriacus (4-1), Muscardinus avellanarius (2-1; 19-1; 4-1), Apodemus sp. (15-1; 18-9; 13-36; 14-10; 16-22; 17-1), Cricetus cricetus (16-1; 7-1; 8-1), Columba livia dom. (4-1), Riparia riparia (16-1), Anthus trivialis (6-1; 9-1), Acrocephalus palustris (16-3), Saxicola torquata (4-1), Saxicola rubetra (9-1), Phoenicurus ochruros (6-1; 11-1; 4-2), Parus major (4-2), Emberiza citrinella (16-1; 4-2), Carduelis carduelis (1-1), Aves sp. juv. (16-1; 5-1), Rana temporaria (16-2), Rana arvalis (16-1), Pelophylax cf. esculentus (16-2), Pelophylax ridibundus $(16-1)$. 


\section{Appendix 12.}

Samples of $T$. alba diet from Východoslovenská pahorkatina Hills. Numerical values in the table are presented in absolute value; positive and negative deviations (1+, 2+, and 1-, 2-) are a marked differences from the mean (Obuch 2001) within a respective species, across locations. For more details see Methods. The diversity index $\mathrm{H}^{\prime}$ is used, calculated according to the work of Shannon \& Weaver (1949).

Vzorky potravy T. alba z Východoslovenskej pahorkatiny. Číselné hodnoty v tabul'ke sú uvedené v absolútnych hodnodnotách, kladné a záporné odchýlky (1+, 2+ a 1-, 2-) sú významné odchýlky od priemeru (Obuch 2001) v rámci toho istého druhu, naprieč lokalitami. Pre viac informácii pozri Metodiku. Použitý je index diverzity H', vypočítaný podla práce Shannon \& Weaver (1949).

\begin{tabular}{|c|c|c|c|c|c|c|c|c|c|c|c|c|c|c|c|}
\hline \multirow{2}{*}{$\begin{array}{l}\text { localities / lokality } \\
\text { taxa / taxón } \\
\text { Parus major }\end{array}$} & & \multicolumn{2}{|r|}{8} & \multicolumn{2}{|r|}{4} & \multicolumn{2}{|r|}{1} & \multicolumn{2}{|r|}{5} & & 2 & & 9 & \multicolumn{2}{|r|}{3} \\
\hline & & $1+$ & 5 & & & & & & & & & & 1 & & \\
\hline Microtus arvalis & $\mathrm{n}$ & $1+$ & 150 & $1+$ & 234 & $1+$ & 184 & $1+$ & 746 & & 84 & & 146 & $1-$ & 40 \\
\hline & $\%$ & & 66.08 & & 65.18 & & 75.41 & & 83.26 & & 48.84 & & 44.24 & & 27.78 \\
\hline Apodemus microps & & & & & & & 3 & $1+$ & 10 & $1+$ & 8 & & 3 & & \\
\hline Arvicola amphibius & & & & & & & & $1+$ & 6 & & & & 1 & & \\
\hline Micromys minutus & & $1-$ & 1 & $1-$ & 2 & $1+$ & 20 & $1-$ & 9 & $1+$ & 10 & $1+$ & 14 & $2+$ & 26 \\
\hline Mus cf. musculus & & $1-$ & 11 & $1-$ & 9 & $2-$ & 1 & $2-$ & 15 & & 9 & $1+$ & 44 & & 14 \\
\hline Sorex araneus & & & 8 & $1-$ & 13 & $1-$ & 6 & $1-$ & 34 & & 9 & $2-$ & 2 & $2+$ & 28 \\
\hline Sorex minutus & & & & $1-$ & 0 & & 6 & $1-$ & 5 & & 4 & & 3 & $1+$ & 9 \\
\hline Myotis myotis & & & & & & & & & & & & & & & \\
\hline Crocidura suaveolens & & & 2 & $2-$ & 0 & & 4 & $2-$ & 3 & & 6 & & 13 & $1+$ & 9 \\
\hline Apodemus flavicollis & & & & & & & & $2-$ & 0 & & 4 & $2+$ & 22 & & \\
\hline Apodemus sylvaticus & & & & & & & & & & & 2 & & 3 & & \\
\hline Apodemus agrarius & & & 4 & $1-$ & 2 & & 7 & $1-$ & 18 & & 10 & $1-$ & 6 & & 9 \\
\hline Terricola subterraneus & & & & & 1 & & 4 & & & & & & 3 & & 2 \\
\hline Neomys anomalus & & & & & & & & & 5 & & 1 & & 3 & & \\
\hline Rattus norvegicus & & & & & & & & & 8 & & & & 2 & & 1 \\
\hline Crocidura leucodon & & & 26 & $1+$ & 74 & $1-$ & 7 & 4- & 2 & & 16 & & 35 & $2-$ & 0 \\
\hline Passer domesticus & & $2-$ & 0 & $1-$ & 6 & $2-$ & 0 & $1-$ & 15 & $1-$ & 0 & & 17 & $1-$ & 0 \\
\hline Passer montanus & & & & & & & & & 5 & & & & & & \\
\hline Neomys fodiens & & & 2 & & & & & & 2 & & 1 & & & & \\
\hline Clethrionomys glareolus & & & 1 & & 1 & & & & & & & & & & \\
\hline Myotis blythii & & & & & & & & & & & & & 4 & & \\
\hline Mammalia & & & 220 & & 351 & & 244 & & 876 & & 172 & & 311 & & 144 \\
\hline Aves & & $1-$ & 6 & $1-$ & 8 & $2-$ & 0 & $1-$ & 20 & $2-$ & 0 & & 19 & $2-$ & 0 \\
\hline Amphibia & & & 1 & & 0 & & 0 & & 0 & & 0 & & 0 & & 0 \\
\hline Invertebrata & & & 0 & & 0 & & 0 & & 0 & & 0 & & 0 & & 0 \\
\hline $\bar{\Sigma}$ & & & 227 & & 359 & & 244 & & 896 & & 172 & & 330 & & 144 \\
\hline $\mathrm{H}^{\prime}$ & & & 1.30 & & 1.14 & & 1.5 & & 0.86 & & 1.92 & & 2.1 & & 1.96 \\
\hline
\end{tabular}

Locality / lokalita: 8 - Suché, 28.12.1979, leg. Riník, 4 - Lesné, 28.12.1979, leg. Riník, 1 - Baškovce, 3.8.1994, 5 - Nacina Ves, 21.1.1986, 2 - Brezina, 27.6.2000, 9 - Vinné, 16.6.1976, 3 - Hencovce, 10.3.1991, leg. Pjenčák, 6 - Petrovce, $4.8 .2000,16$ Vyšná Rybnica, 11.8.1994 + 28.6.2007, leg. Uhrin, Benda, 10 - Vol’a, 1.6.1984, leg. Riník, 11 - Vybuchanec, 7.9.1978, 13 Choňkovce, Anděra et al. (1982), 14 - Jasenov, Anděra et al. (1982), 12 - Zalužice, 5.8.1986, 7 - Pusté Čemerné, 28.12.1979, leg. Riník, 15 - Podhorod', Anděra et al. (1982).

Other species (locality-number) / ostatné druhy (lokalita-počet):

Talpa europaea (14-3; 12-1), Myotis emarginatus (14-1), Eptesicus serotinus (6-1; 16-1), Nyctalus noctula (9-2; 12-1), Plecotus 
Slovak Raptor Journal 2016, 10: 1-50. DOI: 10.1515/srj-2016-0003.

(C) Raptor Protection of Slovakia (RPS)

\begin{tabular}{|c|c|c|c|c|c|c|c|c|c|c|c|c|c|c|c|c|c|c|}
\hline & 6 & & 16 & & 10 & & 11 & & 13 & & 14 & & 12 & & 7 & 15 & $\Sigma$ & $\%$ \\
\hline & & & & & & & & & & & & & & & & & 6 & 0.08 \\
\hline \multirow[t]{5}{*}{$6-$} & 0 & $1-$ & 36 & & 632 & & 58 & & 67 & & 566 & & 989 & $1-$ & 6 & 24 & 3962 & 52.57 \\
\hline & 0.00 & & 25.71 & & 60.42 & & 45.67 & & 54.92 & & 44.01 & & 47.19 & & 26.9 & 52.17 & & \\
\hline & 2 & & 2 & & 2 & & 1 & & & & 6 & $1-$ & 3 & & & & 40 & 0.53 \\
\hline & & & & & 5 & & & & & & & & 1 & & & & 13 & 0.17 \\
\hline & 10 & & & $1-$ & 18 & & 2 & & 3 & $1-$ & 1.20 & & 48 & & 2 & & 185 & 2.45 \\
\hline 2- & 5 & $1-$ & 1.2 & $1-$ & 41 & $1-$ & 2 & & 8 & $1+$ & 244 & & 189 & & & & 594 & 7.88 \\
\hline$\overline{1+}$ & 33 & $2+$ & 43 & & 53 & & 8 & $1-$ & 0 & $1-$ & 49 & & 138 & & 1 & & 425 & 5.64 \\
\hline \multirow[t]{2}{*}{$2+$} & 23 & $2+$ & 15 & & 11 & & 1 & & & $1-$ & 6 & & 36 & & 1 & & 120 & 1.59 \\
\hline & & $2+$ & 14 & & & & & & & & & $1-$ & 0 & & & 1 & 15 & 0.20 \\
\hline$\overline{1+}$ & 18 & & 5 & & 21 & & 2 & & 2 & & 25 & & 61 & & & 1 & 172 & 2.28 \\
\hline$\beta+$ & 42 & & 1 & $1-$ & 1 & & & & & $2-$ & 0 & $2-$ & 1 & & & & 71 & 0.94 \\
\hline $1+$ & 9 & & & & & & & & & & & & & & & & 14 & 0.19 \\
\hline $3+$ & 89 & & 5 & & 42 & $1+$ & 14 & & 1 & $2-$ & 9 & $1-$ & 45 & & 3 & 2 & 266 & 3.53 \\
\hline $1+$ & 9 & & & & 3 & & 1 & & & & 3 & $1-$ & 0 & & & & 26 & 0.35 \\
\hline \multirow[t]{2}{*}{$1+$} & 12 & & 4 & $1+$ & 28 & $1+$ & 9 & & 2 & & 14 & $2-$ & 2 & & 2 & & 82 & 1.9 \\
\hline & 2 & & & $2+$ & 34 & & & & & $2-$ & 0 & $1-$ & 3 & & & & 50 & 0.66 \\
\hline $1-$ & 15 & $1-$ & 4 & & 83 & $1+$ & 21 & $1+$ & 25 & $1+$ & 159 & & 182 & & 1 & 7 & 657 & 8.72 \\
\hline \multirow[t]{6}{*}{$2-$} & 0 & & 4 & & 42 & & 7 & $1-$ & 0 & 4- & 0 & $2+$ & 233 & & 2 & & 326 & 4.33 \\
\hline & & & & & 2 & & & & & & & $1+$ & 14 & & & & 21 & 0.28 \\
\hline & & & & & 1 & & & & & & 2 & & 7 & & & & 15 & 0.20 \\
\hline & 4 & & & & & & & & & & 1 & & 3 & & 1 & & 11 & 0.15 \\
\hline & & & 1 & & & & & & & & & & & & & & 5 & 0.07 \\
\hline & 278 & & 133 & & 998 & & 120 & & 118 & & 1216 & & 1824 & & 18 & 42 & 7065 & 93.75 \\
\hline \multirow[t]{5}{*}{ 3- } & 0 & & 6 & $1-$ & 47 & & 7 & & 4 & & 61 & $1+$ & 263 & & 4 & 4 & 449 & 5.96 \\
\hline & 0 & & 1 & & 1 & & 0 & & 0 & $1+$ & 9 & & 8 & & 1 & 0 & 21 & 0.28 \\
\hline & 0 & & 0 & & 0 & & 0 & & 0 & & 0 & & 1 & & 0 & 0 & 1 & 0.01 \\
\hline & 278 & & 140 & & 1046 & & 127 & & 122 & & 1286 & & 2096 & & 23 & 46 & 7536 & 100.00 \\
\hline & 2.21 & & 2.5 & & 1.64 & & 1.77 & & 1.44 & & 1.78 & & 1.88 & & 2.34 & 1.43 & 1.90 & \\
\hline
\end{tabular}

auritus (13-1), Plecotus austriacus (2-1; 12-1), Muscardinus avellanarius (6-4), Apodemus sp. (8-15; 4-15; 1-2; 5-12; 2-7; 9-5; $3-6 ; 10-23 ; 11-1 ; 13-9 ; 14-106 ; 12-113 ; 7-1 ; 15-7)$, Cricetus cricetus (5-1), Microtus agrestis (14-2), Coturnix coturnix (4-1), Apus apus (10-1), Alauda arvensis (4-1; 9-1; 12-1; 7-1), Hirundo rustica (12-1), Phoenicurus ochruros (16-2; 7-1), Passeriformes (8-1; 10-2; 13-4; 14-61; 12-14; 15-4), Rana temporaria (16-1), Amphibia (8-1; 10-1; 14-9; 12-8; 7-1), Gryllotalpa gryllotalpa $(12-1)$. 


\section{Appendix 13a.}

Samples of $T$. alba diet from Východoslovenská rovina Plain, west. Numerical values in the table are presented in absolute value; positive and negative deviations (1+, 2+, and 1-, 2-) are a marked differences from the mean (Obuch 2001) within a respective species, across locations. For more details see Methods. The diversity index H' is used, calculated according to the work of Shannon \& Weaver (1949).

Vzorky potravy T. alba z Východoslovenskej roviny, západnej časti. Číselné hodnoty v tabul'ke sú uvedené v absolútnych hodnodnotách, kladné a záporné odchýlky (1+, 2+ a 1-, 2-) sú významné odchýlky od priemeru (Obuch 2001) v rámci toho istého druhu, naprieč lokalitami. Pre viac informácii pozri Metodiku. Použitý je index diverzity H', vypočítaný podla práce Shannon \& Weaver (1949).

\begin{tabular}{|c|c|c|c|c|c|c|c|c|c|c|c|c|c|c|c|}
\hline \multirow{2}{*}{$\begin{array}{l}\text { localities / lokality } \\
\text { taxa / taxón } \\
\text { Microtus arvalis }\end{array}$} & \multicolumn{3}{|c|}{16} & \multicolumn{2}{|r|}{7} & \multicolumn{2}{|c|}{3} & \multicolumn{2}{|c|}{2} & \multicolumn{2}{|c|}{11} & \multicolumn{2}{|c|}{12} & \multicolumn{2}{|c|}{10} \\
\hline & $\mathrm{n}$ & $1+$ & 456 & $1+$ & 515 & $1+$ & 92 & $3-$ & 0 & & 75 & & 192 & $1-$ & 88 \\
\hline & $\%$ & & 75.00 & & 81.88 & & 73.02 & & 0.00 & & 65.79 & & 60.00 & & 2.51 \\
\hline Apodemus agrarius & & & 22 & & 19 & $1+$ & 13 & $2+$ & 16 & $1+$ & 16 & $1+$ & 23 & $1+$ & 21 \\
\hline Crocidura suaveolens & & & 5 & $1-$ & 5 & & 1 & & & & 2 & $1+$ & 12 & & 8 \\
\hline Mus cf. musculus & & $2-$ & 5 & $1-$ & 9 & $1-$ & 1 & & 3 & & 6 & $1-$ & 8 & $2+$ & 37 \\
\hline Apodemus microps & & & 24 & $1-$ & 12 & & & & 2 & & 4 & $1+$ & 16 & $1+$ & 22 \\
\hline Micromys minutus & & $1-$ & 2 & & 14 & & 4 & & 4 & & 6 & $1+$ & 13 & $1+$ & 14 \\
\hline Terricola subterraneus & & & 4 & & 6 & & & & & & & & 2 & & 1 \\
\hline Crocidura leucodon & & $1-$ & 16 & $1-$ & 9 & $1-$ & 0 & & & $1-$ & 0 & $1-$ & 6 & $1-$ & 3 \\
\hline Neomys anomalus & & & & & & & & & & & & & & & 1 \\
\hline Sorex minutus & & $1-$ & 4 & $2-$ & 2 & & 3 & & & & & & 8 & & 2 \\
\hline Sorex araneus & & & 41 & $2-$ & 14 & & 6 & & 1 & $1-$ & 2 & $1-$ & 17 & $2-$ & 4 \\
\hline Apodemus flavicollis & & & 4 & $1-$ & 0 & & 1 & & 3 & & & & 3 & & 1 \\
\hline \multicolumn{16}{|c|}{ Muscardinus avellanarius } \\
\hline \multicolumn{16}{|l|}{ Clethrionomys glareolus } \\
\hline Rattus norvegicus & & $1+$ & 13 & & 3 & & & & 4 & & & $1+$ & 13 & & 5 \\
\hline Passer domesticus & & & 3.2 & $1-$ & 12 & $1-$ & 0 & & & $1-$ & 1 & $2-$ & 1 & $2-$ & 0 \\
\hline Passer montanus & & & & & 1 & & & & & & & & & & \\
\hline \multicolumn{16}{|l|}{ Pelobates fuscus } \\
\hline \multicolumn{16}{|l|}{ Pelophylax cf.esculentus } \\
\hline Arvicola amphibius & & & 1 & & & & & & & & & & 3 & & \\
\hline Apodemus sylvaticus & & & 1 & & & & & & & & 2 & & & & \\
\hline \multicolumn{16}{|l|}{ Neomys fodiens } \\
\hline \multicolumn{16}{|l|}{ Alauda arvensis } \\
\hline Talpa europaea & & & & & 1 & & & & & & & & 1 & & \\
\hline Mammalia & & & 602 & & 612 & & 126 & & 38 & & 113 & & 317 & & 207 \\
\hline Aves & & $2-$ & 6 & 1- & 17 & 1- & 0 & & 0 & 1- & 1 & 2- & 3 & $2-$ & 0 \\
\hline Amphibia & & & 0 & & 0 & & 0 & & 0 & & 0 & & 0 & & 0 \\
\hline $\bar{\Sigma}$ & & & 608 & & 629 & & 126 & & 38 & & 114 & & 320 & & 207 \\
\hline $\mathbf{H}^{\prime}$ & & & 1.13 & & 0.92 & & 1.5 & & 1.76 & & 1.23 & & 1.63 & & 1.80 \\
\hline
\end{tabular}

Locality / lokalita: 16 - Bánovce nad Ondavou, 14.7.2005 + 25.8.2006, leg. Sárossy, 7 - Palín, 19.7.1984, 3 - Čel'ovce, 19.10.2000, 2 - Čejkov, 19.6.2000, 11 - Vel'ký Ruskov, 19.10.2000, 12 - Vojčice, 30.8.2005, leg. Sárossy, 10 - Trhovište, 14.7.2005, leg. Sárossy, 4 - Falkušovce, 2003, leg. Vrábel, 1 - Drahňov, 9.4.1975, 8 - Sečovská Polianka, 1997, leg. Pjenčák, 15 - Žbince, 29.12.1979, leg. Riník, 5 - Horovce, 23.6.2003, leg. Krišovský, 9 - Trebišov, 5.2.1982, leg. Hrtan + 2003, leg Krišovský + 18.7 .2003 + 15.9.2004 + 14.3.2005, leg Sárossy, 13 - Lomnica, 17.4.1992, leg. Pjenčák, 14 - Zemplínske Hradište, 4.2.1986, 6 - Michalovce, 17.5.1976. 
Slovak Raptor Journal 2016, 10: 1-50. DOI: 10.1515/srj-2016-0003.

(C) Raptor Protection of Slovakia (RPS)

\begin{tabular}{|c|c|c|c|c|c|c|c|c|c|c|c|c|c|c|c|c|c|c|c|}
\hline \multirow[b]{2}{*}{ 1- } & \multirow{2}{*}{$\begin{array}{ll}4 & \\
& 59\end{array}$} & \multicolumn{2}{|r|}{1} & \multirow{2}{*}{\multicolumn{2}{|c|}{$\begin{array}{l}8 \\
665\end{array}$}} & \multicolumn{2}{|c|}{15} & \multicolumn{2}{|r|}{5} & \multicolumn{2}{|r|}{9} & \multicolumn{2}{|c|}{13} & \multicolumn{2}{|c|}{14} & \multicolumn{2}{|c|}{6} & \multirow{2}{*}{$\begin{array}{c}\Sigma \\
5625\end{array}$} & \multirow{2}{*}{$\begin{array}{l}\% \\
56.44\end{array}$} \\
\hline & & $1-$ & 176 & & & & 312 & $2-$ & 12 & & 1240 & & 36 & & 1682 & $1-$ & 25 & & \\
\hline & 36.88 & & 35.77 & & 58.49 & & 53.89 & & 10.10 & & 49.74 & & 55.38 & & 59.52 & & 43.10 & & \\
\hline \multirow[t]{2}{*}{$2+$} & 34 & $1+$ & 29 & & 34 & $2-$ & 4 & & 3 & & 111 & & 3 & 3- & 8 & & 2 & 358 & 3.59 \\
\hline & 2 & & 6 & $1+$ & 32 & & 14 & & 3 & $1-$ & 28 & & 1 & & 42 & & 2 & 163 & 1.64 \\
\hline \multirow[t]{2}{*}{$1-$} & 1 & & 24 & $1+$ & 110 & $2+$ & 70 & & 9 & $1-$ & 47 & & 1 & & 99 & & 2 & 432 & 4.33 \\
\hline & 2 & & 10 & $1-$ & 20 & 3- & 0 & & 2 & $1+$ & 188 & & 1 & 5- & 0 & & 3 & 306 & 3.7 \\
\hline \multirow[t]{4}{*}{$1+$} & 11 & $1+$ & 22 & & 22 & $1-$ & 6 & & 1 & & 53 & & 1 & $1-$ & 22 & & 2 & 197 & 1.98 \\
\hline & 1 & & 4 & $1+$ & 15 & $1-$ & 0 & & 1 & $1+$ & 32 & $1+$ & 5 & $2-$ & 2 & & & 73 & 0.73 \\
\hline & 10 & $1+$ & 35 & $1+$ & 65 & $1+$ & 45 & & 2 & $1-$ & 64 & & & $1+$ & 147 & $1+$ & 9 & 411 & 4.12 \\
\hline & & & & $1+$ & 11 & & & & & & & & & & 1 & & & 13 & 0.13 \\
\hline $1+$ & 11 & $2+$ & 43 & $1-$ & 11 & 1- & 2 & $1+$ & 9 & $1+$ & 106 & & & $2-$ & 16 & & 1 & 218 & 2.19 \\
\hline \multirow[t]{5}{*}{$1+$} & 26 & $1+$ & 90 & $1-$ & 55 & $2-$ & 11 & $2+$ & 50 & $1+$ & 383 & $1+$ & 14 & $1-$ & 130 & & 7 & 851 & 8.54 \\
\hline & 2 & $1-$ & 0 & & 13 & $1-$ & 0 & & & $2+$ & 90 & & & 4- & 0 & & 1 & 118 & 1.18 \\
\hline & & & & & & & & & & $1+$ & 7 & & 2 & & & & & 9 & 0.09 \\
\hline & 1 & & 2 & & 1 & & & & 1 & $1+$ & 8 & & & & & & & 13 & 0.13 \\
\hline & & & 8 & $1-$ & 3 & $1+$ & 14 & $1+$ & 10 & & 36 & & & $2-$ & 7 & & & 116 & 1.16 \\
\hline \multirow[t]{10}{*}{$2-$} & 0 & & 34 & $2-$ & 12 & $1+$ & 54 & $1-$ & 0 & 5- & 2 & & & $2+$ & 388 & & 3 & 509 & 5.11 \\
\hline & & & 2 & & & & 2 & & & $1-$ & 0 & & & & 12 & & & 17 & 0.17 \\
\hline & & & 1 & & & & & & & & & & & $1+$ & 7 & & & 8 & 0.08 \\
\hline & & & & & & & & & & & & & & $1+$ & 15 & & & 15 & 0.15 \\
\hline & & & 2 & & & & 1 & & & $1-$ & 0 & & 1 & & 9 & & & 17 & 0.17 \\
\hline & & & & & 6 & & & & & & 3 & & & $1-$ & 0 & & 4 & 16 & 0.16 \\
\hline & & & 1 & & 2 & & & & 2 & & 4 & & & & 5 & & & 14 & 0.14 \\
\hline & & & & & & & 1 & & & & 2 & & & & 2 & & 1 & 6 & 0.06 \\
\hline & & & & & & & & & & & 2 & & & & 1 & & & 5 & 0.05 \\
\hline & 160 & & 453 & & 1125 & & 519 & & 107 & & 2484 & & 65 & & 2385 & & 58 & 9371 & 94.02 \\
\hline \multirow[t]{4}{*}{ 2- } & 0 & $1+$ & 38 & 2- & 12 & $1+$ & 60 & & 3 & 4- & 9 & & 0 & $2+$ & 419 & & 5 & 573 & 5.75 \\
\hline & 0 & & 1 & & 0 & & 0 & & 0 & 1- & 0 & & 0 & $1+$ & 22 & & 0 & 23 & 0.23 \\
\hline & 160 & & 492 & & 1137 & & 579 & & 110 & & 2493 & & 65 & & 2826 & & 63 & 9967 & 100.00 \\
\hline & 1.79 & & 2.9 & & 1.67 & & 1.64 & & 1.94 & & 1.84 & & 1.43 & & 1.52 & & 2.6 & 1.81 & \\
\hline
\end{tabular}

Other species (locality-number) / ostatné druhy (lokalita-počet):

Myotis nattereri (1-1), Myotis blythii $(9-1 ; 14-1)$, Nyctalus noctula $(8-1 ; 15-1 ; 14-1)$, Apodemus sp. (16-4; 7-3; 3-5; 2-5; 8-59; 15-38; 5-2; 9-81; 14-208), Cricetus cricetus (15-1; 14-3), Mustela nivalis (14-1), Coturnix coturnix (1-1; 14-2), Streptopelia decaocto (7-1; 14-2), Upupa epops (14-1), Galerida cristata (14-1), Hirundo rustica (12-2; 15-1), Delichon urbica (9-1; 14-1), Motacilla alba (1-1), Lanius minor (14-2), Lanius collurio (14-1), Acrocephalus palustris (9-2), Sylvia curruca (14-1), Saxicola rubetra (9-1), Phoenicurus ochruros (5-3; 14-1), Turdus philomelos (6-1), Parus major (9-1; 14-1), Emberiza citrinella (14-1), Carduelis carduelis (14-1), Chloris chloris (15-1), Sturnus vulgaris (14-2), Passeriformes (16-4; 7-3; 15-1). 


\section{Appendix 13b.}

Samples od T. alba diet from Východoslovenská rovina, east. Numerical values in the table are presented in absolute value; positive and negative deviations (1+, 2+, and 1-, 2-) are a marked differences from the mean (Obuch 2001) within a respective species, across locations. For more details see Methods. The diversity index 'H' is used, calculated according to the work of Shannon \& Weaver (1949).

Vzorky potravy T. alba z Východoslovenskej roviny, východnej časti. Číselné hodnoty v tabul'ke sú uvedené v absolútnych hodnodnotách, kladné a záporné odchýlky (1+, 2+ a 1-, 2-) sú významné odchýlky od priemeru (Obuch 2001) v rámci toho istého druhu, naprieč lokalitami. Pre viac informácii pozri Metodiku. Použitý je index diverzity H', vypočítaný podla práce Shannon \& Weaver (1949).

\begin{tabular}{|c|c|c|c|c|c|c|c|c|c|c|c|c|c|c|c|c|c|}
\hline \multirow{2}{*}{$\begin{array}{l}\text { localities / lokality } \\
\text { taxa / taxón } \\
\text { Clethrionomys glareolus }\end{array}$} & \multirow[b]{3}{*}{$\mathrm{n}$} & \multicolumn{2}{|c|}{15} & \multicolumn{2}{|c|}{11} & \multicolumn{2}{|r|}{2} & \multicolumn{2}{|c|}{7} & \multicolumn{2}{|r|}{9} & \multicolumn{2}{|c|}{10} & \multicolumn{2}{|c|}{1} & \multicolumn{2}{|c|}{8} \\
\hline & & $1+$ & & & & & & & 4 & & & & 4 & & 1 & & \\
\hline \multirow[t]{2}{*}{ Microtus arvalis } & & $1+$ & 1195 & $1+$ & 601 & $1+$ & 65 & $1+$ & 561 & $1-$ & 34 & $1-$ & 100 & $1-$ & 32 & & 605 \\
\hline & $\%$ & & 74.32 & & 68.84 & & 73.86 & \multicolumn{2}{|c|}{69.34} & \multirow{2}{*}{\multicolumn{2}{|c|}{31.19}} & \multirow{2}{*}{\multicolumn{2}{|c|}{37.74}} & \multirow{2}{*}{\multicolumn{2}{|c|}{32.00}} & \multirow{2}{*}{\multicolumn{2}{|c|}{48.63}} \\
\hline Parus major & & & & & & & & $1+$ & 8 & & & & & & & & \\
\hline Apodemus agrarius & & & 84 & $1-$ & 25 & & 5 & $1+$ & 57 & $1+$ & 13 & $2+$ & 63 & & 9 & $1-$ & 41 \\
\hline Terricola subterraneus & & & 17 & $1-$ & 1 & & & & 7 & & 2 & $2+$ & 21 & & 1 & $1+$ & 18 \\
\hline Micromys minutus & & 3- & 10 & $1-$ & 15 & & 3 & $1-$ & 18 & $2+$ & 23 & $1-$ & 5 & & 1 & $2+$ & 248 \\
\hline Mus cf. musculus & & 3- & 8 & & 56 & & 3 & $1-$ & 20 & $1+$ & 17 & $2-$ & 3 & $1+$ & 13 & $2+$ & 211 \\
\hline \multicolumn{18}{|l|}{ Mus spicilegus } \\
\hline Sorex minutus & & $1-$ & 37 & $1-$ & 18 & & 1 & $2-$ & 8 & & 6 & $1-$ & 4 & & 2 & $1-$ & 19 \\
\hline Sorex araneus & & & 144 & $1-$ & 36 & $1-$ & 1 & $2-$ & 23 & $1-$ & 2 & & 25 & & 9 & $1-$ & 49 \\
\hline Rattus norvegicus & & & 9 & & 8 & & 1 & & 12 & & & & 2 & $1+$ & 10 & $1-$ & 3 \\
\hline Crocidura suaveolens & & $2-$ & 5 & & 16 & & 2 & & 10 & & 4 & & 2 & & 2 & & 25 \\
\hline Apodemus flavicollis & & & 8 & & 2 & & & $1-$ & 1 & & & & & & & $2-$ & 0 \\
\hline \multicolumn{18}{|l|}{ Nyctalus noctula } \\
\hline Apodemus sylvaticus & & & 1 & & 5 & & & & 1 & & & & 1 & & 1 & & \\
\hline Apodemus microps & & & 40 & & 26 & & 6 & & 24 & & 6 & $2-$ & 0 & & & $4-$ & 0 \\
\hline Crocidura leucodon & & $2-$ & 19 & & 46 & & & $1-$ & 20 & & 1 & $1-$ & 3 & & 2 & $1-$ & 21 \\
\hline Passer domesticus & & $2-$ & 4 & & 14 & & & $1-$ & 24 & & & $2+$ & 24 & $2+$ & 13 & $3-$ & 0 \\
\hline \multicolumn{18}{|l|}{ Melolontha melolontha } \\
\hline Coleoptera & & & & & & & & & 1 & & & & & & & & \\
\hline Pelobates fuscus & & $1-$ & 0 & & & & & & & & & & & & & $1-$ & 0 \\
\hline \multicolumn{18}{|l|}{ Rana arvalis } \\
\hline Pelophylax kl. esculentus & & & 1 & & 1 & & & & & & & & & & & & \\
\hline Passer montanus & & & 3 & & & & & & 1 & & & & 1 & & & & \\
\hline Arvicola amphibius & & & 4 & & 2 & & & & & & & & & & 2 & & 1 \\
\hline Hirundo rustica & & & 1 & & 1 & & & & & & & & & & & & \\
\hline Neomys fodiens & & & 2 & & & & & & 3 & & & & & & 1 & & \\
\hline Phoenicurus ochruros & & & & & & & 1 & & & & & & & & & & \\
\hline Mammalia & & & 1594 & & 857 & & 87 & & 773 & & 109 & & 239 & & 87 & & 1244 \\
\hline Aves & & 2- & 13 & 1- & 15 & & 1 & $1+$ & 35 & & 0 & $2+$ & 26 & $1+$ & 13 & 4- & 0 \\
\hline Amphibia & & $1-$ & 1 & 1- & 1 & & 0 & $1-$ & 0 & & 0 & & 0 & & 0 & $1-$ & 0 \\
\hline Invertebrata & & 1- & 0 & & 0 & & 0 & & 1 & & 0 & & 0 & & 0 & & 0 \\
\hline$\sum$ & & & 1608 & & 873 & & 88 & & 809 & & 109 & & 265 & & 100 & & 1244 \\
\hline $\mathrm{H}^{\prime}$ & & & 1.13 & & 1.34 & & 1.9 & & 1.39 & & 1.91 & & 1.88 & & 2.15 & & 1.52 \\
\hline
\end{tabular}

Locality / lokalita: 15 - Ižkovce, 16.4.1983, leg. Hrtan + 21.12.2004, leg. Sárossy, 11 - Ostrov, 23.7.1975 + 21.7.2005, leg Sárossy, 2 - Závadka, 15.7.2005, leg. Sárossy, 7 - Senné, 23.4.1962, leg. Weisz + 19.7.1984 + 19.7.1984 + 13.7.2005, leg. Sárossy + 25.4.2015, leg. Dzurjašková, 9 - Príbeník, 20.9.2000, 10 - Pavlovce nad Uhom, 19.7.1984, 1 - Zemplín, 9.5.1983, leg. Hrtan, 8 Ruská, 27.11.2000, 6 - Strážne, 3.8.2005, leg. Sárossy, 3 -Vojka, 27.11.2000 + 14.11.2003, 16 - Bot’any, 20.8.1997 + 27.3.2001, 18 - Blatné Revištia, 10.4.1980, leg. Riník, 5 - Tašula, 18.7.2005, leg. Sárossy, 14 - Jenkovce, 4.8.2000 + 21.7.2005, leg. Sárossy, 17 - Biel, 21.5.1999 + 27.10.1999 + 18.5.2000 + 27.3.2001, 12 -Nižná Rybnica, 10.4.1980, leg. Riník, 13 - Malý Horeš, 20.9.2000, 4 Vel'ký Horeš, 2.8.1995, leg. Uhrin.

Other species (locality-number) / ostatné druhy (lokalita-počet):

Talpa europaea (14-2), Neomys anomalus (1-1; 14-3), Myotis nattereri (14-1), Myotis myotis (17-4), Pipistrellus pipistrellus (17-1), 
Slovak Raptor Journal 2016, 10: 1-50. DOI: 10.1515/srj-2016-0003.

(C) Raptor Protection of Slovakia (RPS)

\begin{tabular}{|c|c|c|c|c|c|c|c|c|c|c|c|c|c|c|c|c|c|c|c|c|}
\hline \multicolumn{2}{|r|}{6} & \multicolumn{2}{|r|}{3} & \multicolumn{2}{|c|}{16} & \multicolumn{2}{|c|}{18} & \multicolumn{2}{|r|}{5} & \multicolumn{2}{|c|}{14} & \multicolumn{2}{|c|}{17} & \multicolumn{2}{|c|}{12} & \multicolumn{2}{|c|}{13} & 4 & $\Sigma$ & $\%$ \\
\hline & 2 & & & & & & & & & & & & & & & & & & 20 & 0.20 \\
\hline \multirow[t]{5}{*}{$1-$} & 120 & & 327 & $2-$ & 21 & & 68 & & 423 & & 615 & $1-$ & 592 & $1-$ & 80 & & 97 & 5 & 5541 & 55.23 \\
\hline & 40.96 & & 50.15 & & 18.75 & & 59.13 & & 61.75 & & 55.51 & & 37.42 & & 43.48 & & 50.00 & 45.45 & & \\
\hline & & & & & & & & & 2 & & & & & & 1 & & & & 11 & 0.11 \\
\hline & 8 & $1+$ & 45 & $1-$ & 0 & $1-$ & 0 & $1-$ & 12 & & 40 & $1-$ & 31 & $1-$ & 1 & & 14 & & 448 & 4.47 \\
\hline & & & 5 & & & & & & 2 & & 8 & $2-$ & 1 & & 1 & & 2 & & 86 & 0.86 \\
\hline \multirow[t]{2}{*}{$1+$} & 29 & & 27 & $1-$ & 1 & & 6 & $1-$ & 12 & $1-$ & 21 & $1-$ & 61 & & 13 & & 9 & & 502 & 5.00 \\
\hline & 13 & $1-$ & 16 & $1-$ & 2 & & 6 & $1-$ & 27 & & 53 & $1+$ & 126 & & 13 & $1+$ & 22 & & 609 & 6.7 \\
\hline $1+$ & 6 & & 1 & & & & & & & & & & & & & & & & 7 & 0.07 \\
\hline $1+$ & 23 & $1+$ & 55 & $2+$ & 19 & $1+$ & 10 & & 30 & & 51 & & 62 & & 12 & & 6 & 2 & 365 & 3.64 \\
\hline \multirow[t]{8}{*}{$1+$} & 54 & $1+$ & 95 & $3+$ & 64 & & 11 & $1+$ & 86 & & 82 & & 149 & & 12 & & 19 & 1 & 862 & 8.59 \\
\hline & 2 & $1-$ & 1 & & & & & $1+$ & 12 & $1+$ & 21 & $1-$ & 5 & & 1 & & & & 87 & 0.87 \\
\hline & 7 & $1-$ & 3 & & & & 6 & & 15 & $1+$ & 30 & $1+$ & 47 & & 5 & & 5 & & 184 & 1.83 \\
\hline & 1 & & 2 & & & & & & 5 & $2+$ & 31 & $1+$ & 21 & & & & 1 & & 72 & 0.72 \\
\hline & & & & & & & & & & $1+$ & 5 & & & & & & & & 5 & 0.05 \\
\hline & & & 2 & & & & & & 1 & & 3 & $1+$ & 12 & & & & & 1 & 28 & 0.28 \\
\hline & 11 & & 29 & & & & & $1+$ & 32 & & 45 & $1+$ & 99 & $1-$ & 0 & & 5 & & 323 & 3.22 \\
\hline & 8 & & 21 & & 3 & & 1 & $2-$ & 9 & & 57 & $2+$ & 203 & $1+$ & 21 & & 4 & 2 & 441 & 4.40 \\
\hline \multirow{8}{*}{\multicolumn{2}{|c|}{$1-$}} & & 8 & & 1 & & 2 & $1-$ & 5 & & 19 & $1+$ & 65 & $1+$ & 15 & & & & 195 & 1.94 \\
\hline & & & & & & & & & & & & $1+$ & & & & & & & 9 & 0.09 \\
\hline & & & & & & & & & & & & $2+$ & 20 & & & & & & 21 & 0.21 \\
\hline & & & 1 & & 1 & & & & & $1-$ & 0 & $2+$ & 40 & & 2 & & & & 44 & 0.44 \\
\hline & & & & & & & & & & & & $1+$ & 7 & & & & & & 7 & 0.07 \\
\hline & & & & & & & & & & & & $1+$ & 7 & & & & & & 9 & 0.09 \\
\hline & & & 1 & & & & & & 2 & & 1 & & 5 & & 1 & & & & 15 & 0.15 \\
\hline & & & 1 & & & & & & & & 2 & & 2 & & & & & & 14 & 0.14 \\
\hline \multirow{2}{*}{\multicolumn{2}{|c|}{2}} & & & & & & & & 3 & & 4 & & & & & & & & 11 & 0.11 \\
\hline & & & & & & & & & & & 1 & & 1 & & & & & & 8 & 0.08 \\
\hline & 2 & & & & & & & & 3 & & 1 & & & & & & & & 7 & 0.07 \\
\hline & 287 & & 642 & & 110 & & 113 & & 666 & & 1071 & & 1420 & & 165 & & 194 & 11 & 9669 & 96.38 \\
\hline & 6 & $1-$ & 9 & & 1 & & 2 & & 19 & & 37 & $1+$ & 77 & $1+$ & 17 & $1-$ & 0 & 0 & 271 & 2.70 \\
\hline & 0 & & 1 & & 1 & & 0 & $1-$ & 0 & $1-$ & 0 & $2+$ & 54 & & 2 & & 0 & 0 & 60 & 0.60 \\
\hline & 0 & & 0 & & 0 & & 0 & & 0 & & 0 & $2+$ & 31 & & 0 & & 0 & 0 & 32 & 0.32 \\
\hline & 293 & & 652 & & 112 & & 115 & & 685 & & 1108 & & 1582 & & 184 & & 194 & 11 & 0,0321 & 100.00 \\
\hline & 1.97 & & 1.77 & & 1.23 & & 1.46 & & 1.53 & & 1.86 & & 2.24 & & 1.95 & & 1.76 & 1.41 & 1.84 & \\
\hline
\end{tabular}

Muscardinus avellanarius (17-1), Apodemus sp. (7-4; 9-1; 10-6; 6-3; 3-12; 18-5; 12-6; 13-10), Cricetus cricetus (15-2; 8-1; 17-1), Microtus agrestis (8-2), Mustela nivalis (17-1), Coturnix coturnix (5-1; 17-1), Columba livia dom. (15-1), Streptopelia decaocto (5-3; 17-1), Streptopelia turtur (7-1), Tyto alba (15-1), Upupa epops (17-1), Alauda arvensis (15-1), Delichon urbica (17-1), Anthus trivialis (17-1), Acrocephalus palustris (6-1), Hippolais icterina (17-1), Phylloscopus collybita (14-2), Erithacus rubecula (15-1; 14-1), Turdus merula (14-2), Turdus philomelos (14-1), Cyanistes caeruleus $(7-1 ; 14-1)$, Poecile palustris (14-1), Fringilla coelebs (10-1; 14-2), Carduelis carduelis (15-1), Chloris chloris (14-1), Sturnus vulgaris (17-1), Passeriformes (14-1), Gryllotalpa gryllotalpa (17-2). 


\section{Appendix 10.}

Samples of T. alba diet from Slovenský kras Mts. Numerical values in the table are presented in absolute value; positive and negative deviations (1+, 2+, and 1-, 2-) are a marked differences from the mean (Obuch 2001) within a respective species, across locations. For more details see Methods. The diversity index H' is used, calculated according to the work of Shannon \& Weaver (1949).

Vzorky potravy $T$. alba zo Slovenského krasu. Číselné hodnoty v tabul'ke sú uvedené v absolútnych hodnodnotách, kladné a záporné odchýlky (1+, 2+ a 1-, 2-) súvýznamné odchýlky od priemeru (Obuch 2001) v rámci toho istého druhu, naprieč lokalitami. Pre viac informácii pozri Metodiku. Použitý je index diverzity H', vypočítaný podla práce Shannon \& Weaver (1949).

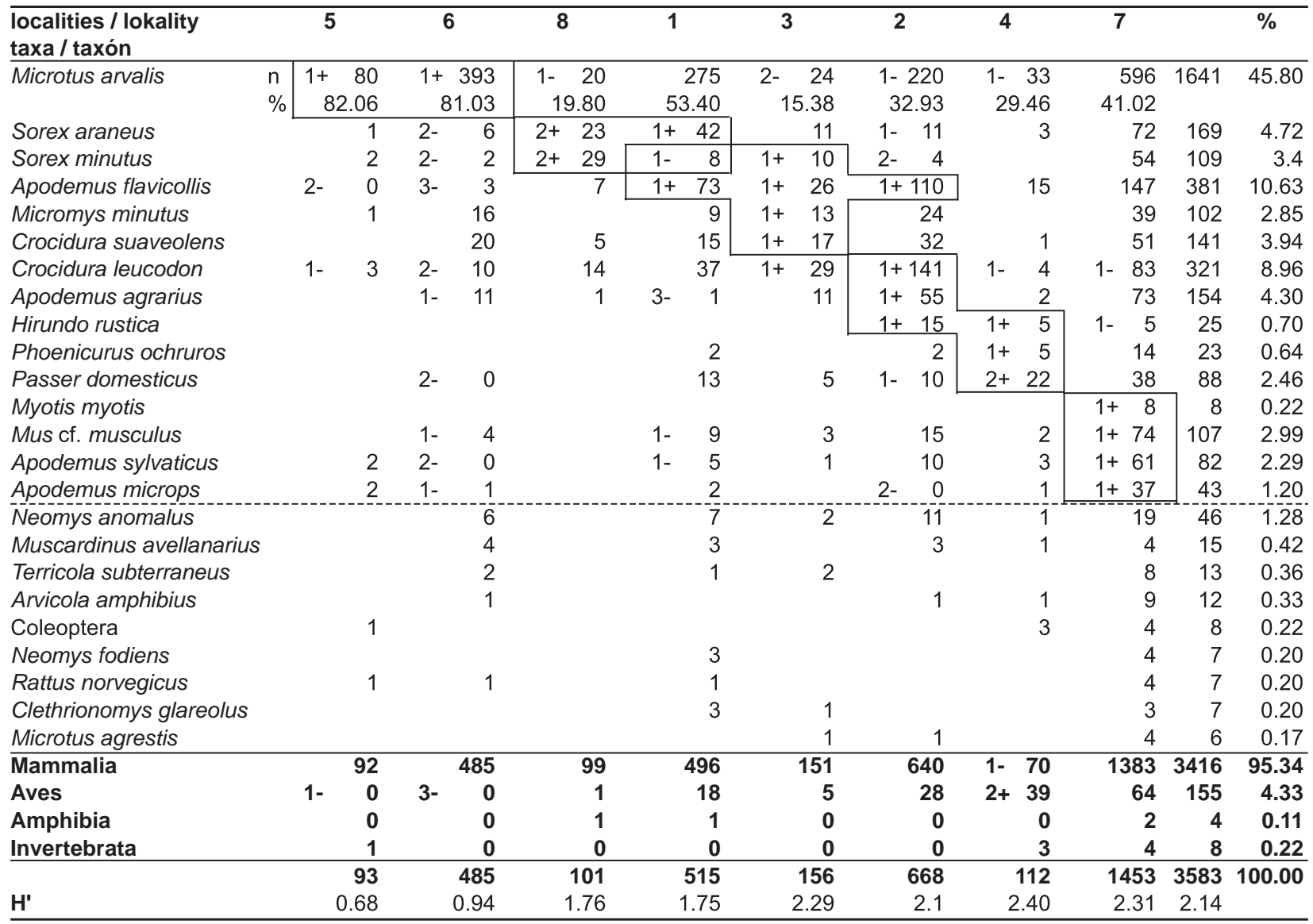

Locality / lokalita: 5 - Drienovec - vinica, 1991, 6 - Krásnohorská Dlhá Lúka, 1.7.2000, leg. Matis, 8 - Tornal'a, Činča, 1.2.2001, 1 - Dlhá Ves, Obuch (1998), 3 - Rozložná, Obuch (1998), 2 - Gemerská Hôrka, Obuch (1998), 4 - Silická Jablonica, Obuch (1998), 7 - Jablonov nad Turňou, 16.9.1992 + 17.2.1998 (Obuch 1998) + 2007, leg. Olekšák.

Other species (locality-number) / ostatné druhy (lokalita-počet):

Talpa europaea (1-1), Myotis emarginatus (6-1; 4-1), Myotis blythii (1-1; 4-1), Eptesicus serotinus (7-1), Pipistrellus pipistrellus (4-1), Plecotus auritus (2-1), Glis glis (2-1), Apodemus sp. (6-4; 7-32), Columba livia dom. (7-1), Apus apus (2-1; 4-1), Picus canus (1-1), Delichon urbica (4-1; 7-2), Motacilla alba (8-1), Muscicapa striata (4-1), Turdus sp. (4-1), Parus major (7-1), Poecile montanus (7-1), Fringilla coelebs (7-1), Linaria cannabina (7-1), Chloris chloris (1-1), Coccothraustes coccothr. (4-1), Passer montanus (4-2), Passeriformes (1-1), Pelobates fuscus (1-1), Rana temporaria (7-1), Pelophylax cf. esculentus (8-1; 7-1). 


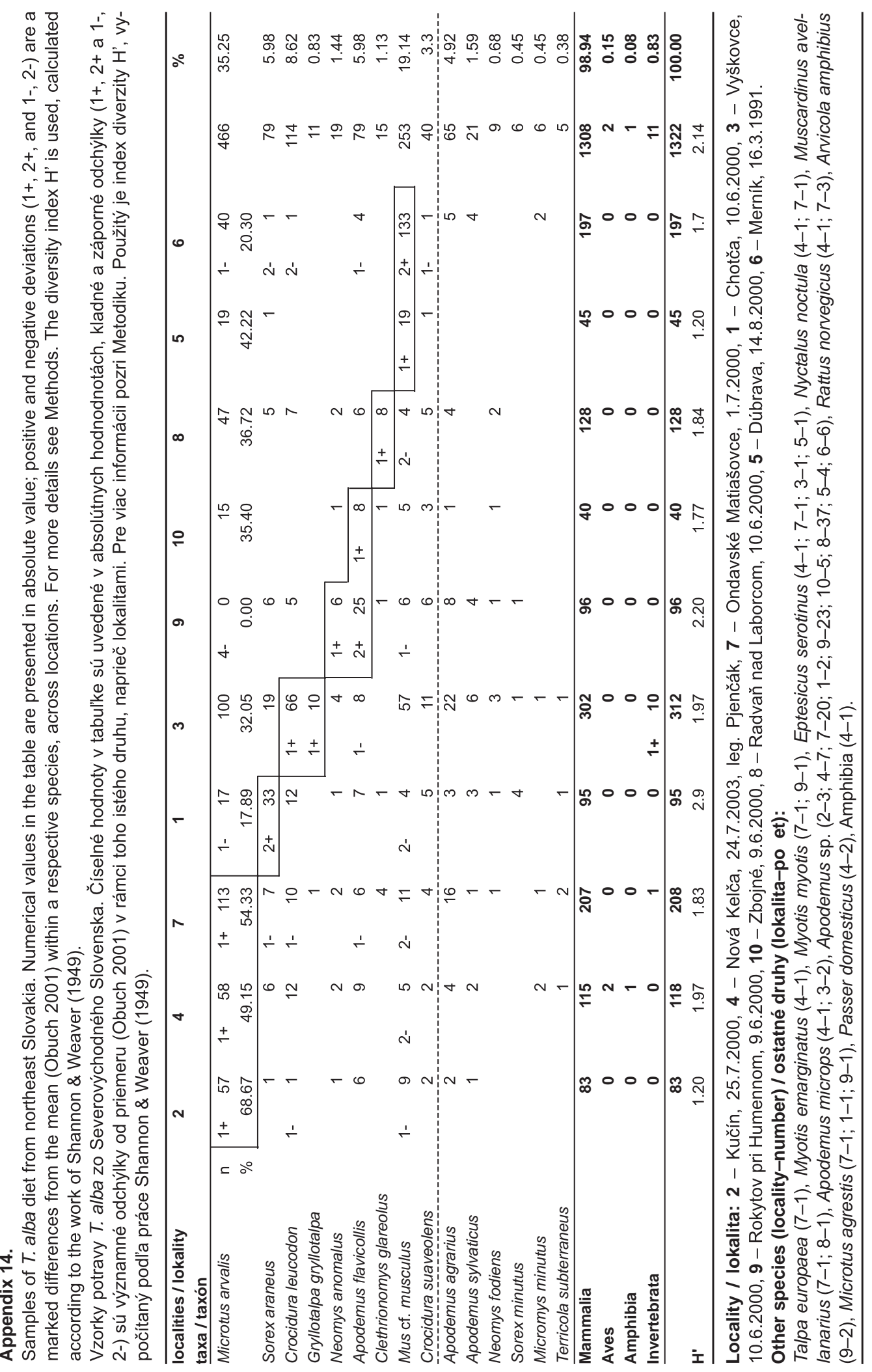




\section{Appendix 15.}

Samples of $T$. alba diet from basins in north Slovakia. Numerical values in the table are presented in absolute value; positive and negative deviations (1+, 2+, and 1-, 2-) are a marked differences from the mean (Obuch 2001) within a respective species, across locations. For more details see Methods. The diversity index H' is used, calculated according to the work of Shannon \& Weaver (1949).

Vzorky potravy T. alba z kotlín severného Slovenska. Číselné hodnoty v tabul'ke sú uvedené v absolútnych hodnodnotách, kladné a záporné odchýlky (1+, 2+ a 1-, 2-) sú významné odchýlky od priemeru (Obuch 2001) v rámci toho istého druhu, naprieč lokalitami. Pre viac informácii pozri Metodiku. Použitý je index diverzity H', vypočítaný podla práce Shannon \& Weaver (1949).

\begin{tabular}{|c|c|c|c|c|c|c|c|c|c|c|c|c|c|}
\hline \multirow{2}{*}{$\begin{array}{l}\text { localities / lokality } \\
\text { taxa / taxón } \\
\text { Neomys anomalus }\end{array}$} & \multicolumn{3}{|r|}{6} & \multicolumn{2}{|c|}{2} & 3 & \multicolumn{2}{|c|}{4} & \multicolumn{2}{|c|}{1} & \multirow[t]{2}{*}{5} & \multirow{2}{*}{$\begin{array}{l}\sum \\
44\end{array}$} & \multirow{2}{*}{$\begin{array}{l}\% \\
3.43\end{array}$} \\
\hline & & $2+$ & 27 & $1-$ & 11 & & $1-$ & 1 & & 5 & & & \\
\hline Sorex araneus & & $1+$ & 13 & & 9 & 1 & & & & 2 & & 25 & 1.95 \\
\hline Arvicola amphibius & & $1+$ & 7 & & 4 & & & 1 & & 1 & 1 & 14 & 1.9 \\
\hline Hirundo rustica & & $1+$ & 8 & $1-$ & 0 & & & & & & & 8 & 0.62 \\
\hline Mus cf. musculus & & & 18 & $1+$ & 141 & $1-$ & $3-$ & 2 & $1-$ & 14 & 1 & 176 & 13.71 \\
\hline Myotis myotis & & & & & 1 & $1+$ & & & & & & 7 & 0.55 \\
\hline Coleoptera & & & & $1-$ & 0 & & $1+$ & 10 & & & & 10 & 0.78 \\
\hline \multirow[t]{2}{*}{ Microtus arvalis } & $\mathrm{n}$ & $1-$ & 90 & & 441 & 25 & & 153 & & 119 & 22 & 850 & 66.20 \\
\hline & $\%$ & & 52.33 & & 63.27 & 69.44 & & 79.27 & & 76.28 & 76.86 & & \\
\hline Apodemus sylvaticus & & $1-$ & 0 & & 20 & & & 10 & & 4 & 1 & 35 & 2.73 \\
\hline Apodemus microps & & & & & 16 & & & 8 & & 5 & & 29 & 2.26 \\
\hline Neomys fodiens & & & 1 & & 4 & 1 & & 1 & & 3 & 1 & 11 & 0.86 \\
\hline Crocidura suaveolens & & & 2 & & 6 & & & 1 & & & 1 & 10 & 0.78 \\
\hline Crocidura leucodon & & & & & 6 & & & & & 2 & & 8 & 0.62 \\
\hline Apodemus flavicollis & & & & & 4 & & & & & 1 & & 5 & 0.39 \\
\hline Mammalia & & & 163 & & 697 & 34 & & 179 & & 156 & 29 & 1258 & 97.98 \\
\hline Aves & & $1+$ & 9 & $2-$ & 0 & 2 & & 4 & & 1 & 0 & 16 & 1.25 \\
\hline Invertebrata & & & 0 & 1- & 0 & 0 & $1+$ & 10 & & 0 & 0 & 10 & 0.78 \\
\hline$\sum$ & & & 172 & & 697 & 36 & & 193 & & 157 & 29 & 1284 & 100.00 \\
\hline $\mathrm{H}^{\prime}$ & & & 1.58 & & 1.28 & 1.1 & & 0.94 & & 1.2 & 0.97 & 1.40 & \\
\hline
\end{tabular}

Locality / lokalita: 6 - Párnica, 2 - Švábovce, 15.8.2000, 3 - Partizánska L’ubča, 23.7.1999, 4 - Ludrová, 2.8.1999, leg. Šmoldas, 1 - Hôrka, 20.9.2001, leg. Repel, 5 - Tvrdošín, 15.8.1998, leg. Hapl.

Other species (locality-number) / ostatné druhy (lokalita-počet):

Talpa europaea (2-1; 4-1), Sorex minutus (6-2; 2-1), Plecotus auritus (3-1), Micromys minutus (6-2; 4-1), Apodemus agrarius (6-1; 5-2), Apodemus sp. (2-29), Rattus norvegicus (2-1), Terricola subterraneus (2-2), Alauda arvensis (4-1), Phoenicurus ochruros (6-1), Erithacus rubecula (4-1), Sitta europaea (4-2), Passer domesticus (3-2; 1-1). 


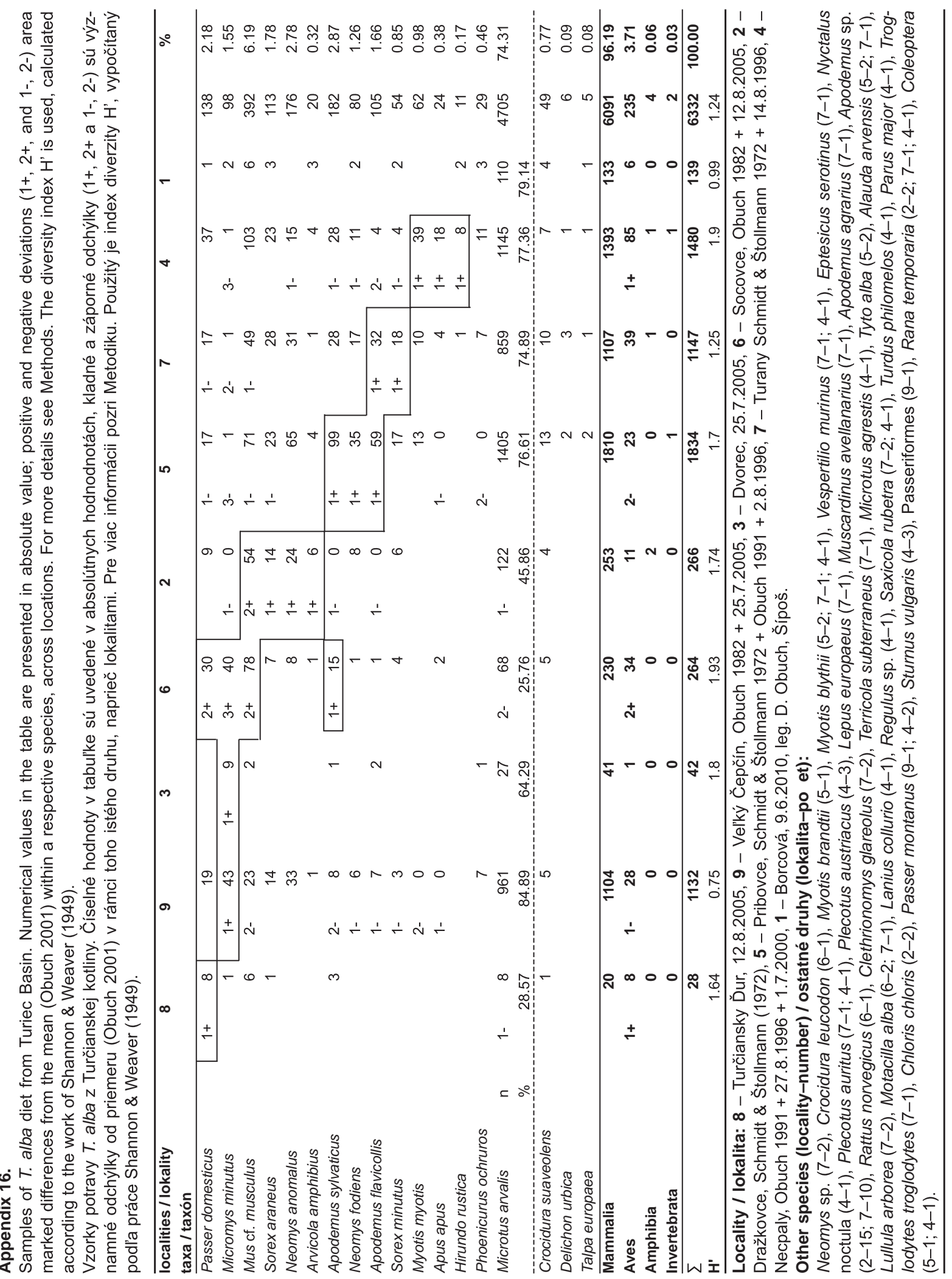




\section{Appendix 17.}

Samples of T. alba diet from Ondavská vrchovina Upland, 1945-1963, leg. T Weisz. Numerical values in the table are presented in absolute value; positive and negative deviations (1+, 2+, and 1-, 2-) are a marked differences from the mean (Obuch 2001) within a respective species, across locations. For more details see Methods. The diversity index $\mathrm{H}^{\prime}$ is used, calculated according to the work of Shannon \& Weaver (1949).

Vzorky potravy T. alba z Ondavskej vrchoviny, zberov T. Weisza z rokov $1945-1963$. Číselné hodnoty v tabul'ke sú uvedené v absolútnych hodnodnotách, kladné a záporné odchýlky (1+, 2+ a 1-, 2-) sú významné odchýlky od priemeru (Obuch 2001) v rámci toho istého druhu, naprieč lokalitami. Pre viac informácii pozri Metodiku. Použitý je index diverzity H', vypočítaný podl'a práce Shannon \& Weaver (1949).

\begin{tabular}{|c|c|c|c|c|c|c|c|c|c|c|c|c|c|c|c|}
\hline \multirow{2}{*}{$\begin{array}{l}\text { localities / lokality } \\
\text { taxa / taxón } \\
\text { Microtus arvalis }\end{array}$} & \multicolumn{3}{|c|}{15} & \multicolumn{2}{|c|}{11} & \multicolumn{2}{|c|}{13} & \multicolumn{2}{|c|}{2} & \multicolumn{2}{|c|}{14} & \multicolumn{2}{|c|}{9} & \multicolumn{2}{|c|}{16} \\
\hline & $\mathrm{n}$ & $1+$ & 1554 & 4- & 0 & $1-$ & 165 & $1-$ & 157 & $1-$ & 3 & & 138 & $1-$ & 314 \\
\hline & $\%$ & & 72.35 & & 0.00 & & 40.54 & & 36.34 & & 16.67 & & 59.48 & & 24.19 \\
\hline Sorex minutus & & $1-$ & 13 & $2+$ & 16 & & 8 & & 8 & & 1 & & 1 & & 19 \\
\hline Sorex araneus & & $1-$ & 62 & $3+$ & 47 & $1+$ & 45 & $1+$ & 45 & & 2 & $1-$ & 4 & & 72 \\
\hline Crocidura suaveolens & & $1-$ & 28 & $2+$ & 24 & & 10 & & 12 & & & & 5 & & 41 \\
\hline Myotis myotis & & $1-$ & 2 & & & $2+$ & 22 & & 1 & & & & 1 & & 8 \\
\hline Terricola subterraneus & & & 1 & & & $1+$ & 5 & & 2 & & & & & & 1 \\
\hline Micromys minutus & & $1-$ & 2 & & & & 4 & $1+$ & 6 & & & & & & \\
\hline Mus cf. musculus & & $1-$ & 191 & $2-$ & 0 & $1-$ & 40 & $1+$ & 83 & $1+$ & 8 & $1+$ & 43 & $1+$ & 283 \\
\hline Neomys anomalus & & $2-$ & 14 & & 1 & & 12 & & 12 & & & $1+$ & 11 & $2+$ & 76 \\
\hline Crocidura leucodon & & & 67 & & & $1-$ & 5 & $1-$ & 6 & & & $1-$ & 2 & $2+$ & 160 \\
\hline Apodemus flavicollis & & $2-$ & 31 & & & $1-$ & 5 & & 14 & & & & 6 & & 65 \\
\hline Apodemus microps & & $1-$ & 12 & & & & 1 & & 1 & & 2 & & 2 & & 15 \\
\hline Arvicola amphibius & & $1-$ & 6 & & & & 2 & & 3 & & & & 4 & $1+$ & 25 \\
\hline Apodemus sylvaticus & & & 41 & & & & 4 & & 13 & & & & 4 & & 24 \\
\hline Apodemus agrarius & & $1-$ & 59 & $1-$ & 0 & $1+$ & 44 & & 17 & & & $1-$ & 3 & $1-$ & 41 \\
\hline Passer domesticus & & & 5 & & & & & & & & 1 & & & & 3 \\
\hline Neomys fodiens & & $1-$ & 4 & & & & 6 & & 7 & & 1 & & 4 & & 12 \\
\hline Clethrionomys glareolus & & $1-$ & 3 & & & & & & 4 & & & & & & 7 \\
\hline Nyctalus noctula & & & 8 & & 1 & & & & & & & & & & 1 \\
\hline Talpa europaea & & & 3 & & & & 1 & & & & & & & & 1 \\
\hline Muscardinus avellanarius & & & 1 & & 1 & & & & & & & & & & 2 \\
\hline Eptesicus serotinus & & & & & 2 & & & & 2 & & & & 1 & & 1 \\
\hline Plecotus auritus & & & & & & & 2 & & 2 & & & & & & 1 \\
\hline Mammalia & & & 2130 & & 92 & & 407 & & 432 & & 17 & & 232 & & 1294 \\
\hline Aves & & & 12 & & 0 & & 0 & & 0 & & 1 & & 0 & & 4 \\
\hline Amphibia & & & 6 & & 0 & & 0 & & 0 & & 0 & & 0 & & 0 \\
\hline$\Sigma$ & & & 2148 & & 92 & & 407 & & 432 & & 18 & & 232 & & 1298 \\
\hline $\mathbf{H}^{\prime}$ & & & 1.24 & & 1.23 & & 2.9 & & 2.12 & & 1.63 & & 1.50 & & 2.29 \\
\hline
\end{tabular}

Locality / lokalita: 15 - Bardejov, 1945 + 5.1946 + 5.1952 + 5.1963, 11 - Vyšná Vol'a, 2.7.1960, 13 - Šašová, 25.6.1963, 2 - Ortut'ová, 25.6.1963, 14 - Richvald, 4.1961, 9 - Lenartov, 20.5.1962, 16 - Nižný Tvarožec, 10.9.1960 + 8.5.1962, 10 - Nižná Vol’a, 5.1962, 3 - Cernina, 28.5.1962, 4 - Dubinné, 11.5.1962, 6 - Hankovce, 11.5.1962, 12 - Šarišské Čierne, 28.5.1962, 7 - Kučín, 11.5.1962, 8 - Kurima, 11.5.1962, 1 - Zlaté, 8.5.1962, 5 - Gaboltov, 12.5.1960 + 1.5.1963.

Other species (locality-number) / ostatné druhy (lokalita-počet):

Rhinolophus hipposideros (16-4), Myotis nattereri (16-1), Vespertilio murinus (15-1), Apodemus sp. (15-27; 13-25; 2-36; 9-2; $16-120 ; 10-13 ; 4-38 ; 6-25 ; 12-17 ; 7-10 ; 8-70 ; 1-3 ; 5-5)$, Microtus agrestis $(13-1 ; 2-1 ; 9-1 ; 12-1)$, Apus apus (15-1), Hirundo rustica (16-1), Phoenicurus ochruros (15-2; 1-1), Passeriformes (15-4; 8-2), Amphibia (15-6; 8-3; 1-1). 
Slovak Raptor Journal 2016, 10: 1-50. DOI: 10.1515/srj-2016-0003.

(C) Raptor Protection of Slovakia (RPS)

\begin{tabular}{|c|c|c|c|c|c|c|c|c|c|c|c|c|c|c|c|c|c|}
\hline \multicolumn{2}{|c|}{10} & \multicolumn{2}{|c|}{3} & \multicolumn{2}{|c|}{6} & \multicolumn{2}{|c|}{4} & \multicolumn{2}{|c|}{12} & \multicolumn{2}{|c|}{7} & \multicolumn{2}{|c|}{8} & 1 & 5 & \multirow{2}{*}{$\begin{array}{c}\Sigma \\
3897\end{array}$} & \multirow{2}{*}{$\begin{array}{c}\% \\
51.02\end{array}$} \\
\hline 1- & 50 & $1-$ & 67 & & 150 & & 173 & & 230 & & 199 & & 582 & 30 & 85 & & \\
\hline & 39.68 & & 33.33 & & 48.39 & & 47.79 & & 49.89 & & 61.80 & & 57.34 & 55.56 & 53.13 & & \\
\hline & 3 & & 5 & & 2 & & 3 & & 6 & & 1 & $1-$ & 7 & 1 & 3 & 97 & 1.27 \\
\hline & 10 & & 17 & $1-$ & 10 & & 22 & & 24 & & 12 & $1-$ & 40 & & 7 & 419 & 5.49 \\
\hline & \multirow[t]{4}{*}{2} & $1+$ & 10 & & 4 & & 5 & & 12 & & 8 & & 21 & & 4 & 186 & 2.44 \\
\hline & & & 1 & & 2 & & 1 & & & & & $1-$ & 0 & & & 38 & 0.50 \\
\hline & & & 1 & & & & & & 1 & & 1 & & & 1 & & 13 & 0.17 \\
\hline & & & 1 & & 4 & & 1 & & & & 1 & & 4 & & & 23 & 0.30 \\
\hline & \multirow[t]{2}{*}{11} & & 26 & & 50 & & 42 & $1-$ & 42 & $1-$ & 27 & & 124 & 8 & 21 & 999 & 13.8 \\
\hline & & & 3 & $1-$ & 0 & & 3 & & 11 & 1- & 0 & $1-$ & 9 & 1 & 2 & 155 & 2.3 \\
\hline $1+$ & 11 & & 4 & & 8 & $2-$ & 2 & 3- & 0 & 1- & 6 & 2- & 9 & & 4 & 284 & 3.72 \\
\hline \multirow[t]{18}{*}{$1+$} & 11 & $1+$ & 14 & $1+$ & 23 & $1+$ & 26 & $1+$ & 49 & & 17 & & 33 & 2 & 9 & 305 & 3.99 \\
\hline & \multirow[t]{2}{*}{1} & $2+$ & 14 & & 3 & & 4 & & 3 & & 7 & $1-$ & 4 & 1 & 1 & 71 & 0.93 \\
\hline & & $1+$ & 11 & & & & & & 2 & & & $1-$ & 1 & 1 & 2 & 57 & 0.75 \\
\hline & 3 & & 8 & $1+$ & 12 & & 6 & & 7 & & 5 & & 13 & 1 & 6 & 147 & 1.92 \\
\hline & \multirow[t]{2}{*}{4} & & 13 & & 13 & $1+$ & 26 & $1+$ & 47 & $1+$ & 25 & & 49 & 1 & 8 & 350 & 4.58 \\
\hline & & & & & & & & & & & & $2+$ & 24 & 2 & & 35 & 0.46 \\
\hline & \multirow[t]{2}{*}{2} & & 3 & & 2 & & 2 & & 4 & & 1 & & 5 & & 1 & 54 & 0.71 \\
\hline & & & 2 & & & & 5 & & 4 & & 1 & & 6 & & & 32 & 0.42 \\
\hline & & & & & 1 & & 1 & & & & & & 2 & & & 14 & 0.18 \\
\hline & 1 & & & & 1 & & & & & & 1 & & 3 & & 1 & 12 & 0.16 \\
\hline & 3 & & 1 & & & & 2 & & 1 & & & & & & & 11 & 0.14 \\
\hline & \multirow[t]{2}{*}{1} & & & & & & & & & & & & 2 & & & 9 & 0.12 \\
\hline & & & & & & & & & & & & & 2 & & 1 & 8 & 0.10 \\
\hline & 126 & & 201 & & 310 & & 362 & & 461 & & 322 & & 986 & 50 & 160 & 7582 & 99.27 \\
\hline & 0 & & 0 & & 0 & & 0 & & 0 & & 0 & $2+$ & 26 & 3 & 0 & 46 & 0.60 \\
\hline & 0 & & 0 & & 0 & & 0 & & 0 & & 0 & & 3 & 1 & 0 & 10 & 0.13 \\
\hline & 126 & & 201 & & 310 & & 362 & & 461 & & 322 & & 1015 & 54 & 160 & 7638 & 100.00 \\
\hline & 2.6 & & 2.27 & & 1.80 & & 1.84 & & 1.79 & & 1.51 & & 1.68 & 1.68 & 1.78 & 1.91 & \\
\hline
\end{tabular}




\section{Appendix 18.}

Overview of the localities with T. alba samples in Slovakia. Explanations: DFS = number of the orographic unit acording to the Databank of Slovak Fauna. Sample's age: 1 - recent collection (1965-2015), 2 - subrecent collection 1945-1961, leg. Weisz, 3 subrecent collection, other samples.

Prehl'ad zberových lokalít vzoriek potravy Tyto alba zo Slovenska. Vysvetlivky: DFS = čísla štvorcov podla Databanky fauny Slovenska. Vek vzorky: 1 - recentný zber (1965 - 2015), 2 - subrecentný zber - zber T. Weisza z rokov 1945 - 1961,3 subrecentný zber - ostatné vzorky.

\begin{tabular}{|c|c|c|c|c|c|c|c|}
\hline $\begin{array}{l}\text { table/ locality / } \\
\text { tabul'ka/ lokalita }\end{array}$ & $\begin{array}{l}\text { locality / } \\
\text { lokalita }\end{array}$ & $\begin{array}{l}\text { geomorfological unit / } \\
\text { geomorfologická jednotka }\end{array}$ & DFS & $\begin{array}{l}\text { m a.s.l. I } \\
\text { m n. m. }\end{array}$ & $\mathbf{E}$ & $\mathbf{N}$ & $\begin{array}{l}\text { sample's age / } \\
\text { vek vzorky }\end{array}$ \\
\hline App. 1/ 1 & Skalica & Chvojnická pahorkatina & 7169 & 170 & 17.2175 & 48.8541 & 1 \\
\hline 2 & Borský Peter & & 7369 & 190 & 17.2238 & 48.6403 & 1 \\
\hline 3 & Štefanov & & 7369 & 180 & 17.2092 & 48.6683 & 1 \\
\hline 4 & Smolinské & & 7368 & 200 & 17.1328 & 48.6831 & 1 \\
\hline 5 & Brodské & & 7268 & 160 & 17.0142 & 48.6950 & 1 \\
\hline 6 & Smrdáky & & 7269 & 250 & 17.3145 & 48.7223 & 1 \\
\hline 7 & Cunín & & 7268 & 160 & 17.1016 & 48.7660 & 1 \\
\hline 8 & Čáry & & 7368 & 170 & 17.0986 & 48.6591 & 1 \\
\hline 9 & Oreské & & 7269 & 250 & 17.3108 & 78.7445 & 1 \\
\hline 10 & Letničie & & 7269 & 210 & 17.1784 & 48.7175 & 1 \\
\hline 11 & Senica & & 7370 & 200 & 17.3269 & 48.6768 & 1 \\
\hline 12 & Petrova Ves & & 7269 & 200 & 17.1634 & 48.7250 & 1 \\
\hline 13 & Chropov & & 7269 & 260 & 17.3206 & 48.7773 & 1 \\
\hline 14 & Dubovce & & 7269 & 220 & 17.2376 & 48.7704 & 1 \\
\hline 15 & Unín & & 7269 & 260 & 17.2059 & 48.7236 & 1 \\
\hline 16 & Prietržka & & 7169 & 180 & 17.1960 & 48.8060 & 1 \\
\hline 17 & Trnovec & & 7269 & 180 & 17.1888 & 48.7999 & 1 \\
\hline 18 & Vrádište & & 7169 & 170 & 17.1976 & 48.8257 & 1 \\
\hline 19 & Hlboké & & 7370 & 230 & 17.4003 & 48.6512 & 1 \\
\hline 20 & Radošovce & & 7269 & 230 & 17.2835 & 48.7597 & 1 \\
\hline 21 & Čáčov & & 7369 & 200 & 17.3272 & 48.6765 & 1 \\
\hline 22 & Radimov & & 7269 & 250 & 17.1888 & 48.7542 & 1 \\
\hline 23 & Gbely & & 7268 & 200 & 17.1313 & 48.7157 & 1 \\
\hline 24 & Popudinské Močidlany & & 7269 & 200 & 17.2143 & 48.7812 & 1 \\
\hline 25 & Kunov & & 7370 & 220 & 17.4036 & 48.6901 & 1 \\
\hline 26 & Rovensko & & 7270 & 220 & 17.3781 & 48.7171 & 1 \\
\hline 27 & Mokrý Háj & & 7169 & 270 & 17.2462 & 48.8074 & 1 \\
\hline 28 & Koválov & & 7269 & 210 & 17.2853 & 78.7021 & 1 \\
\hline 29 & Holíč & & 7168 & 160 & 17.1559 & 48.8018 & 1 \\
\hline 30 & Dojč & & 7369 & 190 & 17.2628 & 48.6849 & 1 \\
\hline 31 & Rybky & & 7270 & 220 & 17.3388 & 48.7078 & 1 \\
\hline 32 & Kopčany & & 7268 & 160 & 17.1268 & 48.7888 & 1 \\
\hline 33 & Horné Suroviny & & 7370 & 220 & 17.3817 & 48.6558 & 1 \\
\hline 34 & Prietrž & & 7370 & 230 & 17.4444 & 48.6698 & 1 \\
\hline App. 2/ 1 & Dolečky & Borská nížina & 7567 & 150 & 16.9339 & 48.4535 & 1 \\
\hline 2 & Gajary & & 7567 & 150 & 16.9295 & 48.4722 & 1 \\
\hline 3 & Jablonica & & 7370 & 210 & 17.4297 & 48.6070 & 1 \\
\hline 4 & Jakubov & & 7567 & 150 & 16.9474 & 48.4108 & 1 \\
\hline 5 & Karlov dvor & & 7567 & 150 & 16.8742 & 48.4121 & 1 \\
\hline 6 & Láb & & 7667 & 150 & 16.9639 & 48.3695 & 1 \\
\hline 7 & Malé Leváre, čerpačka & & 7467 & 150 & 16.9484 & 48.5197 & 1 \\
\hline 8 & Marcheggské mosty & & 7767 & 140 & 16.9557 & 48.2406 & 1 \\
\hline 9 & Nandin dvor & & 7667 & 140 & 16.9402 & 48.3164 & 1 \\
\hline 10 & Plavecký Štvrtok & & 7667 & 150 & 16.9866 & 48.3800 & 1 \\
\hline 11 & Suchohrad & & 7567 & 150 & 16.8571 & 48.4068 & 1 \\
\hline 12 & Vysoká pri Morave & & 7667 & 140 & 16.9179 & 48.3205 & 1 \\
\hline 13 & Záhorská Ves & & 7667 & 150 & 16.8556 & 48.3787 & 1 \\
\hline 14 & Šaštín - Stráže & & 7368 & 170 & 17.1181 & 48.6514 & 1 \\
\hline App. 3/ 1 & Bokroš & Podunajská rovina & 8275 & 110 & 18.2692 & 47.7603 & 1 \\
\hline 2 & Bufa & & 7973 & 110 & 17.8898 & 48.0200 & 1 \\
\hline 3 & Diakovce & & 7873 & 110 & 17.8230 & 48.1339 & 1 \\
\hline 4 & Dropie & & 8072 & 110 & 17.7970 & 47.9213 & 1 \\
\hline 5 & Dunajská Lužná & & 7969 & 130 & 17.2810 & 48.0768 & 1 \\
\hline
\end{tabular}


Slovak Raptor Journal 2016, 10: 1-50. DOI: 10.1515/srj-2016-0003.

(C) Raptor Protection of Slovakia (RPS)

Appendix 18.

Continuation.

Pokračovanie.

\begin{tabular}{|c|c|c|c|c|c|c|c|c|}
\hline \multirow{2}{*}{\multicolumn{2}{|c|}{$\begin{array}{l}\text { table/ locality / } \\
\text { tabul'ka/ lokalita } \\
6\end{array}$}} & $\begin{array}{l}\text { locality / } \\
\text { lokalita }\end{array}$ & $\begin{array}{l}\text { geomorfological unit / } \\
\text { geomorfologická jednotka }\end{array}$ & DFS & $\begin{array}{l}\text { m a.s.l. / } \\
\mathrm{m} \text { n. m. }\end{array}$ & $E$ & $\mathbf{N}$ & $\begin{array}{l}\text { sample's age } \\
\text { vek vzorky }\end{array}$ \\
\hline & & Čalovec & & 8173 & 110 & 17.9826 & 47.8293 & 1 \\
\hline & 7 & Gabčíkovo, Nad Mlynom & & 8171 & 110 & 17.5295 & 47.8661 & 1 \\
\hline & 8 & Horná Potôň & & 7970 & 120 & 17.4991 & 48.0416 & 1 \\
\hline & 9 & Ivanka pri Dunaji & & 7869 & 130 & 17.2668 & 48.1949 & 1 \\
\hline & 10 & Zemianska Olča & & 8173 & 110 & 17.8493 & 47.8175 & 1 \\
\hline & 11 & Lehnice & & 7970 & 120 & 17.4656 & 48.0545 & 1 \\
\hline & 12 & Michal na Ostrove & & 7971 & 120 & 17.5158 & 48.0272 & 1 \\
\hline & 13 & Nový Trh & & 7870 & 120 & 17.4470 & 48.1372 & 1 \\
\hline & 14 & Palárikovo & & 7974 & 110 & 18.0467 & 48.0442 & 1 \\
\hline & 15 & Rusovce & & 7968 & 130 & 17.1398 & 48.0513 & 1 \\
\hline & 16 & Tešedíkovo & & 7873 & 110 & 17.8588 & 48.0961 & 1 \\
\hline & 17 & Šal'a & & 7873 & 110 & 17.8631 & 48.1440 & 1 \\
\hline & 18 & Tvrdošovce & & 7974 & 120 & 18.0536 & 48.1043 & 1 \\
\hline \multirow[t]{10}{*}{ App. 4/ } & 1 & Chorvátsky Grob & Trnavská pahorkatina & 7769 & 150 & 17.3014 & 48.2282 & 1 \\
\hline & 2 & Bernolákovo & Trnavská pahorkatina & 7769 & 130 & 17.3194 & 48.2028 & 1 \\
\hline & 3 & Močenok & Nitrianska pahorkatina & 7773 & 120 & 17.9245 & 48.2125 & 1 \\
\hline & 4 & Bojnice & Hornonitrianska kotlina & 7277 & 330 & 18.5777 & 48.7795 & 1 \\
\hline & 5 & Bystričany & Hornonitrianska kotlina & 7377 & 290 & 18.5311 & 48.6552 & 1 \\
\hline & 6 & Koš & Hornonitrianska kotlina & 7277 & 300 & 18.6035 & 48.7316 & 1 \\
\hline & 7 & Chynorany & Nitrianska pahorkatina & 7375 & 170 & 18.2663 & 48.6054 & 1 \\
\hline & 8 & Ostratice & Nitrianska pahorkatina & 7375 & 190 & 18.2820 & 48.6428 & 1 \\
\hline & 9 & Zemianske Kostolany & Hornonitrianska kotlina & 7377 & 230 & 18.5359 & 48.6793 & 1 \\
\hline & 10 & Pol'ný Kešov & Nitrianska pahorkatina & 7874 & 120 & 18.0655 & 48.1581 & 1 \\
\hline \multirow[t]{7}{*}{ App. 5/ } & 1 & Salka & Ipel'ská pahorkatina & 8176 & 110 & 18.7474 & 47.8969 & 1 \\
\hline & 2 & Pastovce & & 8078 & 120 & 18.7529 & 47.9692 & 1 \\
\hline & 3 & Bátovce & & 7778 & 240 & 18.7399 & 48.2944 & 1 \\
\hline & 4 & Hrkovce & & 7979 & 130 & 18.9024 & 48.0883 & 1 \\
\hline & 5 & Rybník & & 7777 & 180 & 18.5691 & 48.2906 & 1 \\
\hline & 6 & Slatina & & 7879 & 150 & 18.9053 & 48.1490 & 1 \\
\hline & 7 & Malé Kozmálovce & & 7777 & 170 & 18.5192 & 48.2734 & 1 \\
\hline \multirow[t]{20}{*}{ App. 6/ } & 1 & Ivanovo & Hronská pahorkatina & 8076 & 180 & 18.4659 & 47.9011 & 1 \\
\hline & 2 & Arad & & 8176 & 130 & 18.4736 & 47.8769 & 1 \\
\hline & 3 & Kamenný Most & & 8177 & 110 & 18.6536 & 47.8537 & 1 \\
\hline & 4 & Bíňa & & 8077 & 130 & 18.6335 & 47.9211 & 1 \\
\hline & 5 & Čata & & 8077 & 130 & 18.6448 & 47.9536 & 1 \\
\hline & 6 & Tekovské Lužany & & 7977 & 150 & 18.5394 & 48.0994 & 1 \\
\hline & 7 & Vel'ký Dvor & & 7977 & 140 & 18.5975 & 48.0406 & 1 \\
\hline & 8 & Maláš, Arma & & 7977 & 160 & 18.5017 & 48.0599 & 1 \\
\hline & 9 & Čaka & & 7976 & 160 & 18.4637 & 48.0361 & 1 \\
\hline & 10 & Beša & & 7876 & 160 & 18.4033 & 48.1468 & 1 \\
\hline & 11 & Čechy & & 7976 & 170 & 18.3774 & 48.0321 & 1 \\
\hline & 12 & Čifáre & & 7776 & 170 & 18.3971 & 48.2305 & 1 \\
\hline & 13 & Kalnica & & 7777 & 160 & 18.5221 & 48.2056 & 1 \\
\hline & 14 & Nýrovce & & 7977 & 150 & 18.5671 & 48.0191 & 1 \\
\hline & 15 & Plavé Vozokany & & 7976 & 190 & 18.4617 & 48.0777 & 1 \\
\hline & 16 & Žemliare & & 7877 & 150 & 18.603 & 48.1497 & 1 \\
\hline & 17 & Bruty & & 8077 & 150 & 18.5764 & 47.9191 & 1 \\
\hline & 18 & Farná & & 7977 & 170 & 18.5079 & 47.9994 & 1 \\
\hline & 19 & Ket' & & 8077 & 160 & 18.5744 & 47.9610 & 1 \\
\hline & 20 & Tehla & & 7876 & 180 & 18.3816 & 48.1875 & 1 \\
\hline \multirow[t]{7}{*}{$\overline{\text { App. } 7 /}$} & 1 & Dobrá Niva & Pliešovská kotlina & 7580 & 360 & 19.1025 & 48.4716 & 1 \\
\hline & 2 & Gemerský Jablonec & Cerová vrchovina & 7885 & 230 & 19.9761 & 48.1946 & 1 \\
\hline & 3 & Majša & Cerová vrchovina & 7685 & 230 & 19.9756 & 48.3571 & 1 \\
\hline & 4 & Malé Dálovce & Lučenská kotlina & 7783 & 170 & 19.5981 & 48.2420 & 1 \\
\hline & 5 & Breznička & Lučenská kotlina & 7584 & 220 & 19.7363 & 48.4193 & 1 \\
\hline & 6 & Dolné Záhorany & Cerová vrchovina & 7685 & 260 & 19.9027 & 48.3495 & 1 \\
\hline & 7 & Dolná Strehová & Ipel'ská kotlina & 7782 & 180 & 19.4845 & 48.2470 & 1 \\
\hline
\end{tabular}


Appendix 18.

Continuation.

Pokračovanie.

\begin{tabular}{|c|c|c|c|c|c|c|c|}
\hline $\begin{array}{l}\text { table/ locality / } \\
\text { tabul'ka/ lokalita }\end{array}$ & $\begin{array}{l}\text { locality / } \\
\text { lokalita }\end{array}$ & $\begin{array}{l}\text { geomorfological unit / } \\
\text { geomorfologická jednotka }\end{array}$ & DFS & $\begin{array}{l}\mathrm{m} \text { a.s.I. I } \\
\mathrm{m} \mathrm{n.m.}\end{array}$ & $E$ & $\mathbf{N}$ & $\begin{array}{l}\text { sample's age / } \\
\text { vek vzorky }\end{array}$ \\
\hline 8 & Bušince & Ipel'ská kotlina & 7882 & 160 & 19.5010 & 48.1735 & 1 \\
\hline 9 & Pet'ov & Ipel'ská kotlina & 7882 & 150 & 19.4810 & 48.1077 & 1 \\
\hline 10 & Selešt’any & Ipel'ská kotlina & 7982 & 180 & 19.3458 & 48.0965 & 1 \\
\hline 11 & Sklabiná & Ipel'ská kotlina & 7882 & 160 & 19.3527 & 48.1620 & 1 \\
\hline 12 & Hrabovo & Lučenská kotlina & 7684 & 210 & 19.7175 & 48.3902 & 1 \\
\hline 13 & Senné & Ostrôžky & 7682 & 250 & 19.3963 & 48.3109 & 1 \\
\hline App. 8/ 1 & Bottovo & Rimavská kotlina & 7686 & 200 & 20.1455 & 48.3134 & 1 \\
\hline 2 & Behynce & & 7587 & 170 & 20.2945 & 48.4223 & 1 \\
\hline 3 & Bátka & & 7687 & 180 & 20.1718 & 48.3710 & 1 \\
\hline 4 & Chanava & & 7687 & 170 & 20.2963 & 48.3340 & 1 \\
\hline 5 & Dubovec & & 7786 & 180 & 20.1491 & 48.2950 & 1 \\
\hline 6 & Gortva & & 7786 & 190 & 20.0279 & 48.2963 & 1 \\
\hline 7 & Levkuška & & 7587 & 190 & 20.2646 & 48.4577 & 1 \\
\hline 8 & Lenka & & 7688 & 210 & 20.3464 & 48.3850 & 1 \\
\hline 9 & Malé Teriakovce & & 7585 & 230 & 19.9763 & 48.4367 & 1 \\
\hline 10 & Radnovce & & 7687 & 170 & 20.2070 & 48.3388 & 1 \\
\hline 11 & Rimavské Janovce & & 7686 & 200 & 20.0613 & 48.3420 & 1 \\
\hline 12 & Rumince & & 7687 & 180 & 20.2842 & 48.3692 & 1 \\
\hline 13 & Rakytník & & 7687 & 190 & 20.1724 & 48.3968 & 1 \\
\hline 14 & Uzovská Panica & & 7586 & 190 & 20.1498 & 48.4158 & 1 \\
\hline 15 & Velký Blh & & 7686 & 210 & 20.1138 & 48.4504 & 1 \\
\hline 16 & Gemerská Ves & & 7587 & 190 & 20.2729 & 48.4749 & 1 \\
\hline 17 & Číž & & 7687 & 170 & 20.2799 & 48.3131 & 1 \\
\hline App. 9/ 1 & Ratková & Revúcka vrchovina & 7486 & 300 & 20.0943 & 48.5910 & 1 \\
\hline 2 & Budíkovany & & 7586 & 220 & 20.0954 & 48.4848 & 1 \\
\hline 3 & Gemerský Milhost' & & 7487 & 230 & 20.2873 & 48.5927 & 1 \\
\hline 4 & Licince & & 7487 & 210 & 20.2984 & 48.5387 & 1 \\
\hline 5 & Lipovec & & 7486 & 520 & 20.0649 & 48.5499 & 1 \\
\hline 6 & Nandraž & & 7387 & 290 & 20.1875 & 48.6081 & 1 \\
\hline 7 & Nižná Kaloša & & 7587 & 190 & 20.2247 & 48.4221 & 1 \\
\hline 8 & Nižná Pokoradz & & 7586 & 330 & 20.0239 & 48.4067 & 1 \\
\hline 9 & Otročok & & 7587 & 200 & 20.2797 & 48.4524 & 1 \\
\hline 10 & Prihradzany & & 7487 & 270 & 20.2391 & 48.5843 & 1 \\
\hline 11 & Ratkovská Lehota & & 7486 & 290 & 20.0996 & 48.5625 & 1 \\
\hline 12 & Šivetice & & 7487 & 230 & 20.2754 & 48.5814 & 1 \\
\hline 13 & Teplý Vrch & & 7586 & 220 & 20.1017 & 48.4703 & 1 \\
\hline 14 & Višňové & & 7487 & 280 & 20.1904 & 48.5165 & 1 \\
\hline 15 & Hucín & & 7487 & 230 & 20.2987 & 48.5659 & 1 \\
\hline App. 10/1 & Dlhá Ves & Slovenský kras & 7588 & 330 & 20.4379 & 48.4946 & 1 \\
\hline 2 & Gemerská Hôrka & & 7488 & 220 & 20.3778 & 48.5342 & 1 \\
\hline 3 & Rozložná & & 7388 & 280 & 20.3504 & 48.6146 & 1 \\
\hline 4 & Silická Jablonica & & 7489 & 240 & 20.6068 & 48.5582 & 1 \\
\hline 5 & Drienovec-vinica & & 7391 & 190 & 20.9227 & 48.6166 & 1 \\
\hline 6 & Krásnohorská DIhá Lúka & & 7389 & 300 & 20.5802 & 48.6261 & 1 \\
\hline 7 & Jablonov nad Turňou & & 7490 & 260 & 20.6726 & 48.5958 & 1 \\
\hline 8 & Tornala-Činča & Bodvianska pahorkatina & 7588 & 220 & 20.3803 & 48.4367 & 1 \\
\hline App. 11/1 & Budulov & Košická kotlina & 7491 & 190 & 20.9916 & 48.5858 & 1 \\
\hline 2 & Janík & & 7491 & 190 & 20.9723 & 48.5547 & 1 \\
\hline 3 & Cestice & & 7492 & 210 & 21.1008 & 48.5904 & 1 \\
\hline 4 & Paňovce & & 7392 & 240 & 21.0626 & 48.6474 & 1 \\
\hline 5 & Valaliky & & 7393 & 190 & 21.2984 & 48.6354 & 1 \\
\hline 6 & Vyšný Čaj & & 7394 & 240 & 21.3990 & 48.6839 & 1 \\
\hline 7 & Sady nad Torysou & & 7294 & 210 & 21.3489 & 48.7075 & 1 \\
\hline 8 & Bidovce & & 7294 & 240 & 21.4386 & 48.7368 & 1 \\
\hline 9 & Královce & & 7193 & 210 & 21.3311 & 48.8030 & 1 \\
\hline 10 & Brestov & & 7194 & 300 & 21.3503 & 48.8701 & 1 \\
\hline 11 & Košická Polianka & & 7394 & 190 & 21.3436 & 48.6928 & 1 \\
\hline
\end{tabular}


Slovak Raptor Journal 2016, 10: 1-50. DOI: 10.1515/srj-2016-0003.

(C) Raptor Protection of Slovakia (RPS)

Appendix 18.

Continuation.

Pokračovanie.

\begin{tabular}{|c|c|c|c|c|c|c|c|}
\hline $\begin{array}{l}\text { table/ locality / } \\
\text { tabul'ka/ lokalita }\end{array}$ & $\begin{array}{l}\text { locality / } \\
\text { lokalita } \\
\end{array}$ & $\begin{array}{l}\text { geomorfological unit / } \\
\text { geomorfologická jednotka }\end{array}$ & DFS & $\begin{array}{l}\mathrm{m} \text { a.s.l. / } \\
\mathrm{m} \mathrm{n.m.}\end{array}$ & $E$ & $\mathbf{N}$ & $\begin{array}{l}\text { sample's age / } \\
\text { vek vzorky }\end{array}$ \\
\hline 12 & Milhost' & & 7493 & 170 & 21.2685 & 48.5404 & 1 \\
\hline 13 & Kechnec & & 7493 & 170 & 21.2646 & 48.5475 & 1 \\
\hline 14 & Gyňov & & 7493 & 170 & 21.3043 & 48.5906 & 1 \\
\hline 15 & Vyšná Myšl’a & & 7394 & 240 & 21.3081 & 48.6344 & 1 \\
\hline 16 & Seňa & & 7493 & 180 & 21.2594 & 48.5556 & 1 \\
\hline 17 & Belža & & 7493 & 180 & 21.274 & 48.5807 & 1 \\
\hline 18 & Trstené pri Hornáde & & 7494 & 170 & 21.3337 & 48.5731 & 1 \\
\hline 19 & Košické Olšany & & 7294 & 200 & 21.3452 & 48.7325 & 1 \\
\hline 20 & Nižný Lánec & & 7492 & 200 & 21.1095 & 48.5381 & 1 \\
\hline App. 12/1 & Baškovce & Východoslovenská pahorkatina & 7299 & 180 & 22.2066 & 48.7856 & 1 \\
\hline 2 & Brezina & & 7495 & 180 & 21.5542 & 48.5484 & 1 \\
\hline 3 & Hencovce & & 7196 & 120 & 21.7304 & 48.8729 & 1 \\
\hline 4 & Lesné & & 7296 & 140 & 21.8156 & 48.7993 & 1 \\
\hline 5 & Nacina Ves & & 7197 & 120 & 21.8537 & 48.8194 & 1 \\
\hline 6 & Petrovce & & 7299 & 300 & 22.3228 & 48.7068 & 1 \\
\hline 7 & Pusté Čemerné & & 7196 & 130 & 21.8175 & 48.8412 & 1 \\
\hline 8 & Suché & & 7296 & 130 & 21.8338 & 48.7686 & 1 \\
\hline 9 & Vinné & & 7197 & 160 & 21.9674 & 48.8117 & 1 \\
\hline 10 & Vol'a & & 7197 & 130 & 21.8503 & 48.8443 & 1 \\
\hline 11 & Vybúchanec & & 7196 & 130 & 21.8164 & 48.8206 & 1 \\
\hline 12 & Zalužice & & 7297 & 130 & 21.9935 & 48.7616 & 1 \\
\hline 13 & Choňkovce & & 7299 & 190 & 22.2369 & 48.7782 & 1 \\
\hline 14 & Jasenov & & 7299 & 160 & 22.1649 & 48.7907 & 1 \\
\hline 15 & Podhorod' & Vihorlatské vrchy & 7199 & 340 & 22.2300 & 48.8192 & 1 \\
\hline 16 & Vyšná Rybnica & Východoslovenská pahorkatina & 7199 & 220 & 22.1765 & 48.8216 & 1 \\
\hline App. 13a/1 & Drahňov & Východoslovenská rovina & 7497 & 110 & 21.9687 & 48.5918 & 1 \\
\hline 2 & Cejkov & & 7596 & 170 & 21.7616 & 48.4689 & 1 \\
\hline 3 & Čel'ovce & & 7395 & 140 & 21.6287 & 48.6003 & 1 \\
\hline 4 & Falkušovce & & 7396 & 100 & 21.8431 & 48.6274 & 1 \\
\hline 5 & Horovce & & 7296 & 100 & 21.771 & 48.7064 & 1 \\
\hline 6 & Michalovce & & 7297 & 110 & 21.9163 & 48.7543 & 1 \\
\hline 7 & Palín & & 7397 & 100 & 21.9881 & 48.6557 & 1 \\
\hline 8 & Sečovská Polianka & & 7296 & 130 & 21.6802 & 48.7865 & 1 \\
\hline 9 & Trebišov & & 7396 & 110 & 21.722 & 48.6188 & 1 \\
\hline 10 & Trhovište & & 7296 & 130 & 21.8073 & 48.6991 & 1 \\
\hline 11 & Vel'ký Ruskov & & 7396 & 130 & 21.6778 & 48.6507 & 1 \\
\hline 12 & Vojčice & & 7396 & 110 & 21.7103 & 48.6803 & 1 \\
\hline 13 & Vranov -Lomnica & & 7196 & 130 & 21.6727 & 48.8566 & 1 \\
\hline 14 & Zemplínske Hradište & & 7496 & 100 & 21.7358 & 48.5822 & 1 \\
\hline 15 & Žbince & & 7397 & 110 & 21.8752 & 48.6710 & 1 \\
\hline 16 & Bánovce nad Ondavou & & 7396 & 120 & 21.8148 & 48.6809 & 1 \\
\hline App. 13b/1 & Zemplín & Východoslovenská rovina & 7596 & 110 & 21.8079 & 48.4416 & 1 \\
\hline 2 & Závadka & & 7298 & 120 & 22.0719 & 48.7663 & 1 \\
\hline 3 & Vojka & & 7597 & 100 & 21.9125 & 48.4618 & 1 \\
\hline 4 & Velký Horeš & & 7697 & 100 & 21.9114 & 48.3845 & 1 \\
\hline 5 & Tašul'a & & 7399 & 100 & 22.1686 & 48.6593 & 1 \\
\hline 6 & Strážne & & 7697 & 100 & 21.8628 & 48.3674 & 1 \\
\hline 7 & Senné & & 7398 & 100 & 22.0324 & 48.6663 & 1 \\
\hline 8 & Ruská & & 7498 & 100 & 22.1418 & 48.5288 & 1 \\
\hline 9 & Pribeník & & 7698 & 100 & 22.0064 & 48.3901 & 1 \\
\hline 10 & Pavlovce nad Uhom & & 7398 & 110 & 22.0675 & 48.6116 & 1 \\
\hline 11 & Ostrov & & 7298 & 110 & 22.1591 & 48.7156 & 1 \\
\hline 12 & Nižná Rybnica & & 7298 & 120 & 22.1515 & 48.7542 & 1 \\
\hline 13 & Malý Horeš & & 7697 & 100 & 21.9527 & 48.3960 & 1 \\
\hline 14 & Jenkovce & & 7399 & 110 & 22.2092 & 48.6547 & 1 \\
\hline 15 & Ižkovce & & 7497 & 100 & 21.9573 & 48.5579 & 1 \\
\hline 16 & Botany & & 7598 & 100 & 22.0989 & 48.4616 & 1 \\
\hline
\end{tabular}


Appendix 18.

Continuation.

Pokračovanie.

\begin{tabular}{|c|c|c|c|c|c|c|c|}
\hline $\begin{array}{l}\text { table/ locality / } \\
\text { tabul'ka/ lokalita }\end{array}$ & $\begin{array}{l}\text { locality / } \\
\text { lokalita }\end{array}$ & $\begin{array}{l}\text { geomorfological unit / } \\
\text { geomorfologická jednotka }\end{array}$ & DFS & $\begin{array}{l}\mathrm{m} \text { a.s.l. / } \\
\mathrm{m} \mathrm{n.m.}\end{array}$ & $E$ & $\mathbf{N}$ & $\begin{array}{l}\text { sample's age / } \\
\text { vek vzorky }\end{array}$ \\
\hline 17 & Biel & & 7598 & 110 & 22.0569 & 48.4033 & 1 \\
\hline 18 & Blatné Revištia & & 7298 & 110 & 22.0792 & 48.7329 & 1 \\
\hline App. 14/1 & Chotča & Ondavská vrchovina & 6796 & 210 & 21.6784 & 49.2422 & 1 \\
\hline 2 & Kučín & & 6794 & 220 & 21.4579 & 49.2067 & 1 \\
\hline 3 & Vyškovce & & 6796 & 230 & 21.6698 & 49.2508 & 1 \\
\hline 4 & Nová Kelča & & 6996 & 180 & 21.6944 & 49.0598 & 1 \\
\hline 5 & Dúbrava & Beskydské predhorie & 7094 & 300 & 21.4934 & 48.9903 & 1 \\
\hline 6 & Merník & & 7095 & 170 & 21.6382 & 48.9476 & 1 \\
\hline 7 & Ondavské Matiašovce & & 7096 & 130 & 21.7464 & 48.9349 & 1 \\
\hline 8 & Radvaň nad Laborcom & Laborecká vrchovina & 6897 & 230 & 21.9326 & 49.1296 & 1 \\
\hline 9 & Rokytov pri Humennom & & 6897 & 230 & 21.9894 & 49.1010 & 1 \\
\hline 10 & Zbojné & & 6897 & 270 & 21.9954 & 49.1375 & 1 \\
\hline App. 15/1 & Hôrka & Popradská kotlina & 6988 & 620 & 20.3970 & 49.0201 & 1 \\
\hline 2 & Švábovce & & 6988 & 640 & 20.3541 & 49.0294 & 1 \\
\hline 3 & Partizánska L'upča & Liptovská kotlina & 6982 & 570 & 19.4360 & 49.0646 & 1 \\
\hline 4 & Ludrová & & 6981 & 550 & 19.3295 & 49.0515 & 1 \\
\hline 5 & Tvrdošín & Oravská kotlina & 6881 & 570 & 19.5536 & 49.3348 & 1 \\
\hline 6 & Párnica & Oravská vrchovina & 6683 & 460 & 19.1865 & 49.1934 & 1 \\
\hline App. 16/1 & Borcová & Turčianska kotlina & 7079 & 450 & 18.8383 & 48.9252 & 1 \\
\hline 2 & Dražkovce & & 6979 & 430 & 18.9614 & 49.0489 & 1 \\
\hline 3 & Dvorec & & 7078 & 460 & 18.8124 & 48.9090 & 1 \\
\hline 4 & Necpaly & & 7079 & 510 & 18.9662 & 48.9911 & 1 \\
\hline 5 & Príbovce & & 6979 & 420 & 18.8813 & 49.0044 & 1 \\
\hline 6 & Socovce & & 7079 & 450 & 18.8683 & 48.9518 & 1 \\
\hline 7 & Turany & & 6880 & 400 & 19.0384 & 49.1180 & 1 \\
\hline 8 & Turčiansky Ďur & & 7079 & 460 & 18.8381 & 48.9501 & 1 \\
\hline 9 & Vel'ký Čepčín & & 7178 & 470 & 18.8042 & 48.8924 & 1 \\
\hline App. 17/1 & Zlaté & Ondavská vrchovina & 6693 & 390 & 21.2007 & 49.3396 & 2 \\
\hline 2 & Ortutová & & 6794 & 230 & 21.4564 & 49.2698 & 2 \\
\hline 3 & Cernina & & 6794 & 320 & 21.4746 & 49.2972 & 2 \\
\hline 4 & Dubinné & & 6794 & 220 & 21.4402 & 49.2438 & 2 \\
\hline 5 & Gaboltov & & 6692 & 400 & 21.1424 & 49.3655 & 2 \\
\hline 6 & Hankovce & & 6794 & 250 & 21.4050 & 49.2025 & 2 \\
\hline 7 & Kučín & & 6794 & 220 & 21.4579 & 49.2067 & 2 \\
\hline 8 & Kurima & & 6794 & 210 & 21.4537 & 49.2259 & 2 \\
\hline 9 & Lenartov & & 6692 & 480 & 21.0212 & 49.3106 & 2 \\
\hline 10 & Nižná Vol'a & & 6794 & 270 & 21.3708 & 49.2243 & 2 \\
\hline 11 & Vyšná Vol'a & & 6794 & 340 & 21.3620 & 49.2493 & 2 \\
\hline 12 & Šarišské Čierne & & 6694 & 370 & 21.3865 & 49.3451 & 2 \\
\hline 13 & Šašová & & 6794 & 230 & 21.4482 & 49.2565 & 2 \\
\hline 14 & Richvald & & 6793 & 380 & 21.1859 & 49.2771 & 2 \\
\hline 15 & Bardejov & & 6793 & 280 & 21.2681 & 49.2947 & 2 \\
\hline 16 & Nižný Tvarožec & & 6693 & 420 & 21.1873 & 49.3638 & 2 \\
\hline \multirow{3}{*}{$\begin{array}{ll}\text { Tab. 2/ } & 3 \\
& 4 \\
& 5\end{array}$} & Šurice, Soví hrad & Cerová vrchovina & 7785 & 250 & 19.9123 & 48.2261 & 3 \\
\hline & Hatiny, jaskyňa & Slovenský kras & 7392 & 260 & 21.0022 & 48.6522 & 3 \\
\hline & Žilina, Rudiny & Žilinská kotlina & 6778 & 340 & 18.7275 & 49.2162 & 3 \\
\hline
\end{tabular}

